EGD (CERCLA)-002/0790

\title{
Catalog of CERCLA Applicable or Relevant and Appropriate Requirements (ARARs) - Fact Sheets
}

July 1990

PREPARED BY:

U.S. DEPARTMENT OF ENERGY

OFFICE OF ENVIRONMENTAL GUIDANCE

RCRA/CERCLA DIVISION

EH-231

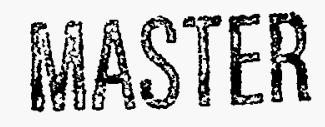

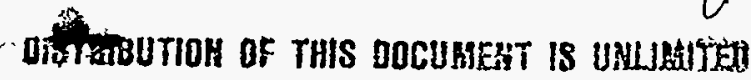




\section{DISCLAIMER}

This report was prepared as an account of work sponsored by an agency of the United States Government. Neither the United States Government nor any agency thereof, nor any of their employees, make any warranty, express or implied, or assumes any legal liability or responsibility for the accuracy, completeness, or usefulness of any information, apparatus, product, or process disclosed, or represents that its use would not infringe privately owned rights. Reference herein to any specific commercial product, process, or service by trade name, trademark, manufacturer, or otherwise does not necessarily constitute or imply its endorsement, recommendation, or favoring by the United States Government or any agency thereof. The views and opinions of authors expressed herein do not necessarily state or reflect those of the United States Government or any agency thereof. 


\section{DISCLAIMER}

Portions of this document may be illegible in electronic image products. Images are produced from the best available original document. 
Quick Reference Fact Sheets

Section

Introduction

1) Superfund IDR Guide \#1, Overview

........ A of RCRA Land Disposal Restrictions (IDR)

2) Superfund LDR Guide \#2, Complying

B with the California List Restrictions under LDRs

3) Superfund LDR Guide \#3, Treatment Standards and Minimum Technology

Requirements under LDRs

4) Superfund LDR Guide \#4, Complying

with Hammer Restrictions under LDRs

5) Superfund LDR Guide \#5, Determining when LDRs are Applicable to CERCLA Response Actions

6) Superfund LDR Guide \#6A, obtaining a Soil and Debris Treatability Variance for Remedial Actions

7) Superfund LDR Guide \#7, Determining when LDRs are Relevant and Appropriate to CERCLA Response Actions

8) Guide to Manual

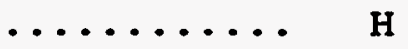

9) CERCLA Compliance with State Requirements

10) CERCLA Compliance with the CWA and SDWA

11) Overview of ARARs-Focus on ARAR Waivers 
12) Summary of Part II CAA, TSCA, and $\ldots \ldots \ldots \ldots$ L Other statutes

13) RCRA ARARs: Focus on Closure

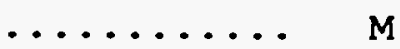
Requirements

14) ARARs Short Guidance Quarterly Report

15) ARARS Q's and A's 


\section{INTRODUCTION}

Section 121(d) of the Comprehensive Environmental Response Compensation and Liability Act (CERCLA) as amended by the Superfund Amendments and Reauthorization Act of 1986 (SARA), requires attainment of federal and state applicable or relevant and appropriate requirements (ARARs). Subpart $E$, Section $300.400(\mathrm{~g})$ "Identification of applicable or relevant and appropriate requirements" of the National Oil and Hazardous Substances Pollution Contingency Plan (NCP)(55 FR 8666, March 8, 1990) describes the process for attaining ARARs.

The purpose of this catalog is to provide DOE Program Offices and Field Organizations with all of the "Quick Reference Fact Sheets" on attaining ARARs. These fact sheets provide overviews of ARARs for CERCLA cleanup actions pertinent to DOE environmental restoration activities. All of the fact sheets in this catalog were prepared by the Environmental Protection Agency's Office of Solid Waste and Emergency Response.

Fact sheets 1-7 discuss land disposal restrictions (LDRs) and their applicability. LDRs may pertain to a number of CERCLA response actions at DOE facilities.

Fact Sheets 8-13 are based on the CERCLA Compliance with Other Laws Manual: Parts $I$ and II and provide an overview of many other CERCLA ARARs. ${ }^{1}$ Overview of ARARs-Focus on ARAR Waivers (fact sheet 11), provides a good introduction to ARARs.

The last two fact sheets, 14 and 15, are periodic reports that describe additional fact sheets and clarify issues.

${ }^{1}$ CERCLA Compliance with Other Laws Manual: Part I (EPA/540/G-89/006); CERCLA Compliance with Other Laws Manual Part II (EPA/540/G-89/009). 


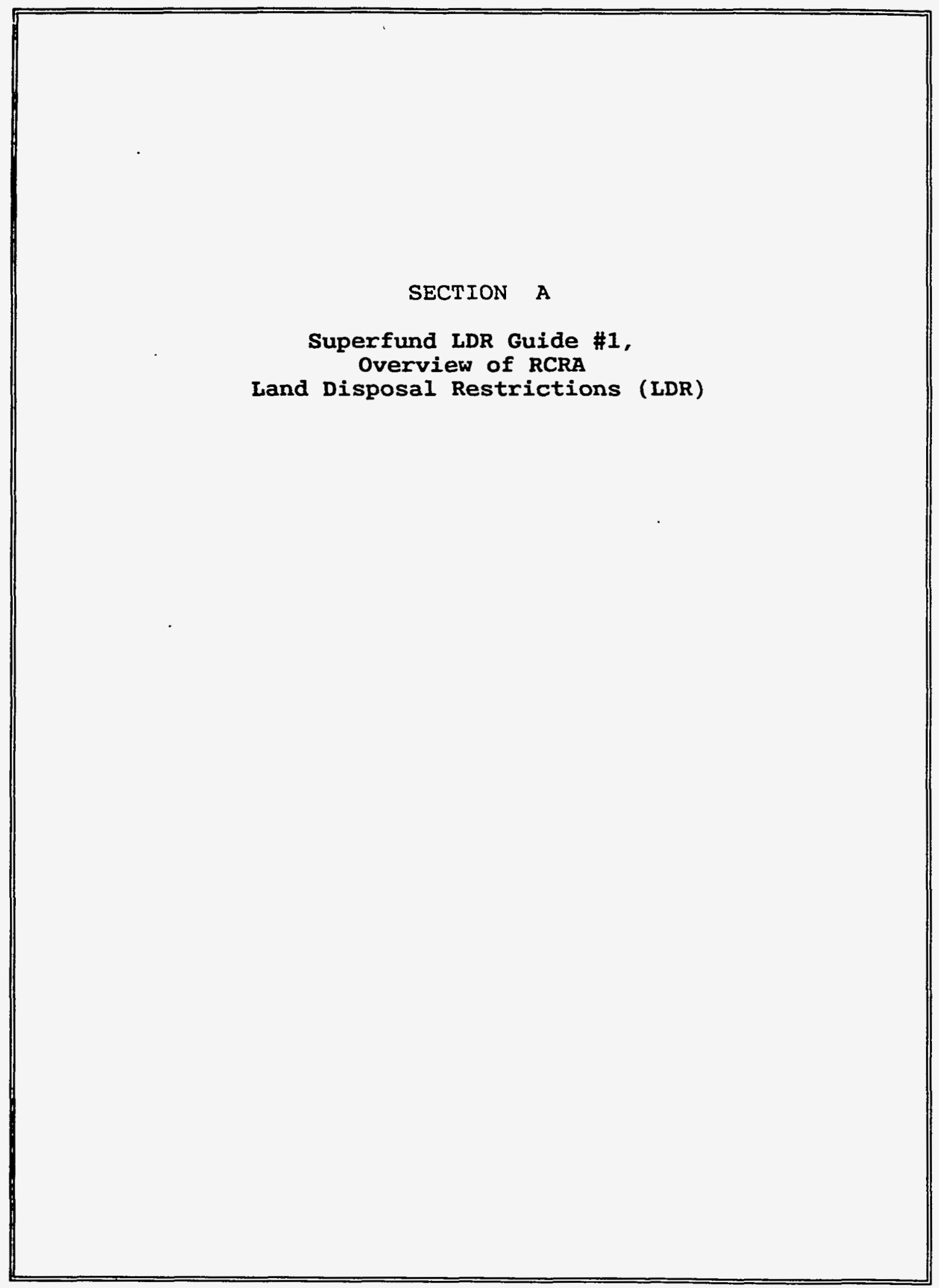


The Hazardous and Solid Waste Amendments (HSWA) to the Resource Conservation and Recovery Act (RCRA) - - P.L. 98-616, signed on November 8, 1984 - - include specific provisions restricting the land disposal of RCRA hazardous wastes. The purpose of these HSWA provisions is to minimize the potential of future risk to human health and the environment by requiring the treatment of hazardous wastes prior to their land disposal. This guide summarizes the major components of the land disposal restrictions (LDRs), outlines the types of restrictions imposed, and presents the compliance options specified in the regulation. Other Superfund LDR Guides are listed at the end of this guide. More detailed guidance on Superfund compliance with the LDRs is being prepared by the Office of Solid Waste and Emergency Response (OSWER).

\section{DEFINITION OF LAND DISPOSAL}

The LDRs place restrictions on the land disposal of RCRA hazardous wastes. The definition of land disposal (or "placement," which is synonymous with "land disposal") under RCRA includes, but is not limited to:

any "placement" of hazardous waste in a landfill, surface impoundment, waste pile, injection well, land treatment facility, salt dome formation, salt bed formation, underground mine or cave, and concrete bunker or vault. (RCRA $\$ 3004(\mathrm{k}))$

The LDRs apply only to RCRA hazardous wastes that are land disposed or placed. They do not apply to wastes that are discharged to surface waters (where National Pollutant Discharge Elimination System (NPDES) requirements apply) or to Publicly Owned Treatment Works (where pretreatment requirements apply). The LDRs also do not apply to contaminated ground water treated and supplied directly to households (where Maximum Contaminant Levels (MCLs) generally apply).

It is important to note that the LDRs apply prospectively to wastes that are land disposed after the effective date of the restrictions (i.e., the LDRs do not require that wastes land disposed prior to the date of the restrictions be removed and treated).

\section{STATUTORY DEADLINES}

HSWA directed EPA to establish treatment standards for each of seven groups of RCRA hazardous wastes by specific dates. These dates, referred to as statutory deadlines, will eventually restrict land disposal of all RCRA hazardous wastes, as shown in Highlight 1.

Highlight 1: LDR STATUTORY DEADLINES

\begin{tabular}{|c|c|}
\hline Waste & Statutory Deadline \\
\hline $\begin{array}{l}\text { Spent Solvent and Diouir- } \\
\text { Contrining Wastes }\end{array}$ & November 8, 1986 \\
\hline Califomia Iist Wastes & Jaty 8, 1987 \\
\hline First Third Wastes & August 8, 1988 \\
\hline $\begin{array}{l}\text { Spent Solvent, Diorin- } \\
\text { Containing, and Califomia } \\
\text { List SoIl and Debris From } \\
\text { CERCLA/RCRA Corrective } \\
\text { Actions }\end{array}$ & Norember 8, 1988 \\
\hline Second Thind Wastes & June 8, 1989 \\
\hline Third Third Wastes & May 8, 1990 \\
\hline $\begin{array}{l}\text { Newiy Identified } \\
\text { Wastes }\end{array}$ & $\begin{array}{l}\text { Within } 6 \text { months of } \\
\text { identification as a } \\
\text { hacandous waste }\end{array}$ \\
\hline
\end{tabular}


The statutory deadlines are important because they are the dates on which RCRA wastes become "restricted," although EPA has the authority to restrict a waste before its statutory deadline. For example, the Agency has restricted certain Second Third wastes in the First Third rule and certain Third Third wastes in the June 1989 Second Third rule.

\section{STATUTORY WASTE CATEGORIES}

The first category of wastes (refer to Highlight 1) includes: the F001-F005 spent solvent-containing RCRA wastes and the F020-F023 and F026-F028 dioxincontaining RCRA wastes. The second category, the California list wastes, is a distinct category of RCRA hazardous wastes described further in Superfund LDR Guide \#2. The three categories of scheduled wastes (i.e., First Third, Second Third, Third Third wastes) include all listed and characteristic hazardous wastes identified as of November 8, 1984 (excluding the solvent and dioxin wastes mentioned above). EPA ranked the scheduled wastes based on their toxicity and volume and placed the highest toxicity/volume wastes in the "First Third." Soil and debris (see Highlight 2) contaminated with spent solvent- or dioxin-containing and California list wastes generated during CERCLA response and RCRA corrective actions were given a separate statutory deadline. Finally. wastes newly identified or listed after 1984 must have standards set within six months of their identification or listing as a hazardous waste.

Highlight 2: DEFINITIONS OF SOIL AND DEBRIS

Soil is defined as materials that are primarily of geologic origin such as sand, silt, loam, or clay that are indigenous to the natural geological environment at or near the CERCLA site. (In many cases, soil is mixed with liquids, sludges, and/or debris.)

Debris is defined as materials that are primarily non-geologic in origin such as grass, trees, stumps, and man-made materials such as concrete, clothing, partially buried whole or empty drums, capacitors, and other synthetic manufacturing items, such as liners. (It does not include synthetic organic chemicals, but may include materials contaminated with these chemicals.)

\section{TYPES OF LDR RESTRICTIONS}

As discussed above, a RCRA hazardous waste becomes "restricted" under the LDRs on its statutory deadline (or earlier if EPA promulgates the restriction ahead of schedule). On that date, one of four types of restrictions will apply:

1. Treatment standards: EPA may set one of three types of treatment standards for restricted wastes:

- A concentration level to be achieved prior to disposal (the most common type of treatment standard);

- A specified technology to be used prior to disposal; or

- A "no land disposal" designation when the waste is no longer generated, is totally recycled, is not currently being land disposed, or no residuals are produced from treatment.

All three types of treatment standards are established based on the best demonstrated available technology (BDAT) identified for that waste.

2. Minimum technology requirements during a national capaciry extension: When EPA sets a treatment standard. it may grant a national capacity extension (for up to two years) if sufficient treatment capacity is not available for that waste. During a national capacity extension, the treatment standards set for a waste do not have to be met. However, if wastes that do not meet the standards are disposed of in a landfill or surface impoundment, the receiving unit must meet the RCRA minimum technology requirements (i.e., double liner, leachate collection system, and ground-water monitoring).

When EPA sets treatment standards for Third Third wastes in May 1990, it may grant a national capacity extension, but only for up to two years. Therefore, by May 1992, all national capacity extensions will have expired. The only exception may be if EPA grants an extension when it sets treatment standards for newly identified wastes. Superfund LDR Guide \#3 provides additional information on the minimum technology requirements.

3. Soft hammer restrictions: If EPA fails to set a treatment standard for a First or Second Third 
waste by its statutory deadline, soft hammer restrictions apply. The soft hammer requirements place the following restrictions on the disposal of wastes in landfills and surface impoundments:

- The receiving unit must meet minimum technology requirements; and

- Site managers (OSCs, RPMs as generators) must determine if treatment is practically available. If treatment is practically available, the site manager must use the best practically available treatment to treat wastes before disposal; if treatment is not practically available, the wastes may be disposed of without treatment.

Land disposal in other types of units, such as land treatment units and waste piles. is not restricted under soft hammers. although an LDR notification will be required for actions involving off-site disposal in such units.

Soft hammer restrictions remain in effect until EPA sets a treatment standard, or until May 1990, when the hard hammer restrictions become effective.

4. Hard hammer restrictions: If EPA fails to set a treatment standard by the statutory deadlines for solvent- and dioxin-containing and California list wastes, or by May 8, 1990, for any of the scheduled wastes, the hard hammer restrictions prohibit all land disposal of the affected waste until a treatment standard is promulgated. To date, the hard hammer has only fallen for certain California list wastes.

Superfund LDR Guide \#4 provides more information on soft and hard hammer restrictions.

\section{LDR COMPLIANCE OPTIONS}

EPA recognizes that not all wastes can be treated to the LDR treatment standards and that alternative treatment standards and methods of land disposal may provide significant reduction in the toxicity, mobility, or volume of wastes and be protective of human health and the environment. The LDRs, therefore, provide the following compliance options to meeting the restrictions discussed above.

- Treatability Variance: This option is available when EPA has set a treatment standard as a concentration level, but because a generator's waste differs significantly from the waste used to set the standard, the promulgated treatment standard cannot be met or the BDAT technology is inappropriate for that waste. (For the purposes of the LDRs, CERCLA site managers are considered generators of hazardous waste.) Under a Treatability Variance, EPA approves an alternate treatment standard that must be met before that waste can be land disposed. Superfund LDR Guides \#6A and \#6B provide more information for obtaining Treatability Variances for remedial and removal actions.

- Equivalent Treatment Method Petition: This option is available when EPA has set a treatment standard that is a specified technology (e.g., incineration). Generators may use a different technology (e.g., chemical treatment) if they can demonstrate that this technology will achieve a measure of performance equivalent to that of the specified technology.

- vio Migration Petition: This option may be used to meet any of the four types of LDR restrictions. Under this option, generators may land dispose wastes that do not meet the LDR restrictions if they can demonstrate that there wiil be "no migration" of hazardous constituents ti.sve bealthbased levels from the disposal unit or injection zone for as long as the wastes remain hazardous.

- Delisting. This option may be used to demonstrate that a waste is nonhazardous and. therefore, not subject to any of the RCRA Subtitle $C$ hazardous waste regulations, including the LDRs. Delisting only applies when the CERCLA waste is a listed RCRA hazardous waste. (Characteristic wastes need not be delisted, but they can be treated to no longer exhibit the characteristic.) Generators must demonstrate that: (1) the waste does not meet any of the criteria for which the waste was listed as a hazardous waste, and (2) other factors (including additional constituents) do not cause the waste to be hazardous.

The LDRs also permit a case-by-case extension of up to two years, which allows a site-specific extension of the effective date if a generator has a binding contractual commitment for treatment capacity and can show that no capacity currently exists anywhere in the United States. This option, however, is generally not appropriate for Superfund response actions.

\section{SOIL AND DEBRIS WASTES}

As discussed earlier, the LDRs apply to soil and debris when they are contaminated with a restricted RCRA hazardous waste. Because of the complex 
nature of many soil and debris matrices (as compared with the industrial process wastes upon which the LDR treatment standards were based), it may be difficult to meet these standards for wastes mixed with soil and debris. Consequently, the Agency is undertaking a rulemaking that will set LDR treatment standards specifically for soil and debris. Until that rulemaking is completed, however, site managers may need to obtain a Treatability Variance for actions addressing contaminated soil and debris.

\section{OTHER LDR REQUIREMENTS}

In addition to the four types of restrictions described above, the LDRs also include the following requirements:

- Storage Prohibition: The LDRs prohibit the storage of restricted wastes (including soft hammer wastes) unless storage is solely for the purpose of accumulating sufficient quantities of wastes to facilitate proper treatment, recovery, or disposal. For periods of up to one year, the burden is generally on EPA to prove that storage is not needed to facilitate proper treatment, recovery, or disposal; after one year, the burden of proof shifts to the storage facility. Temporary storage used during CERCLA actions to facilitate proper disposal (e.g., storage while awaiting sampling results, or while selecting and designing a remedy) is allowable under the storage probibition.

- Exemption for Treatment in Surface Impoundments: Placing untreated wastes in surface impoundments (that meet the minimum technology requirements) for treatment is permissible, provided the treatment residues that do not meet the LDR treatment standards or prohibition levels are removed for subsequent management (through any treatment other than treatment in another surface impoundment) within one year of placement into the surface impoundment.

- Dilution Prohibition: Dilution of a waste as a means to comply with the LDRs is prohibited. However, "dilution" that is part of treatment (e.g., mixing for immobilization) is permissible.

The LDRs also establish requirements for testing, notification, and certification of compliance.
- Testing: Once it is determined that a waste is restricted under the LDRs, generators, treatment facilities, or disposal facilities must test the waste at a frequency specified in the facility's waste analysis plan to demonstrate compliance with LDR treatment standards or California list prohibition levels prior to land disposal.

- Notification: All restricted wastes that are shipped to an off-site treatment, storage, or disposal facility must be accompanied by a notification that includes the EPA hazardous waste number and the applicable LDR restriction that is in effect for those wastes.

- Certification: A treatment facility must certify that the LDR treatment standards are attained before a restricted waste is land disposed off-site. (There are also certification requirements specifically for soft hammer wastes; see Superfund LDR Guide \#4.)

\section{OTHER AVAILABLE SUPERFUND/LDR GUIDES}

\#2 Complying with the California List Restrictions Lnder LDRs

\#3 Treatment Standards and Minimum Technology Requirements Under LDRs

\#4 Complying W'ith the Hammer Restrictions Under LDRs

\#5 Determining When LDRs are Applicable to CERCLA Response Actions

\#6A Obtaining a Soil and Debris Treatability Variance for Remedial Actions

\#6B Obtaining a Soil and Debris Treatability Variance for Removal Actions*

\#7 Determining When LDRs Are Relevant and Appropriate to CERCLA Response Actions*

*Currently being prepared in OSWER 


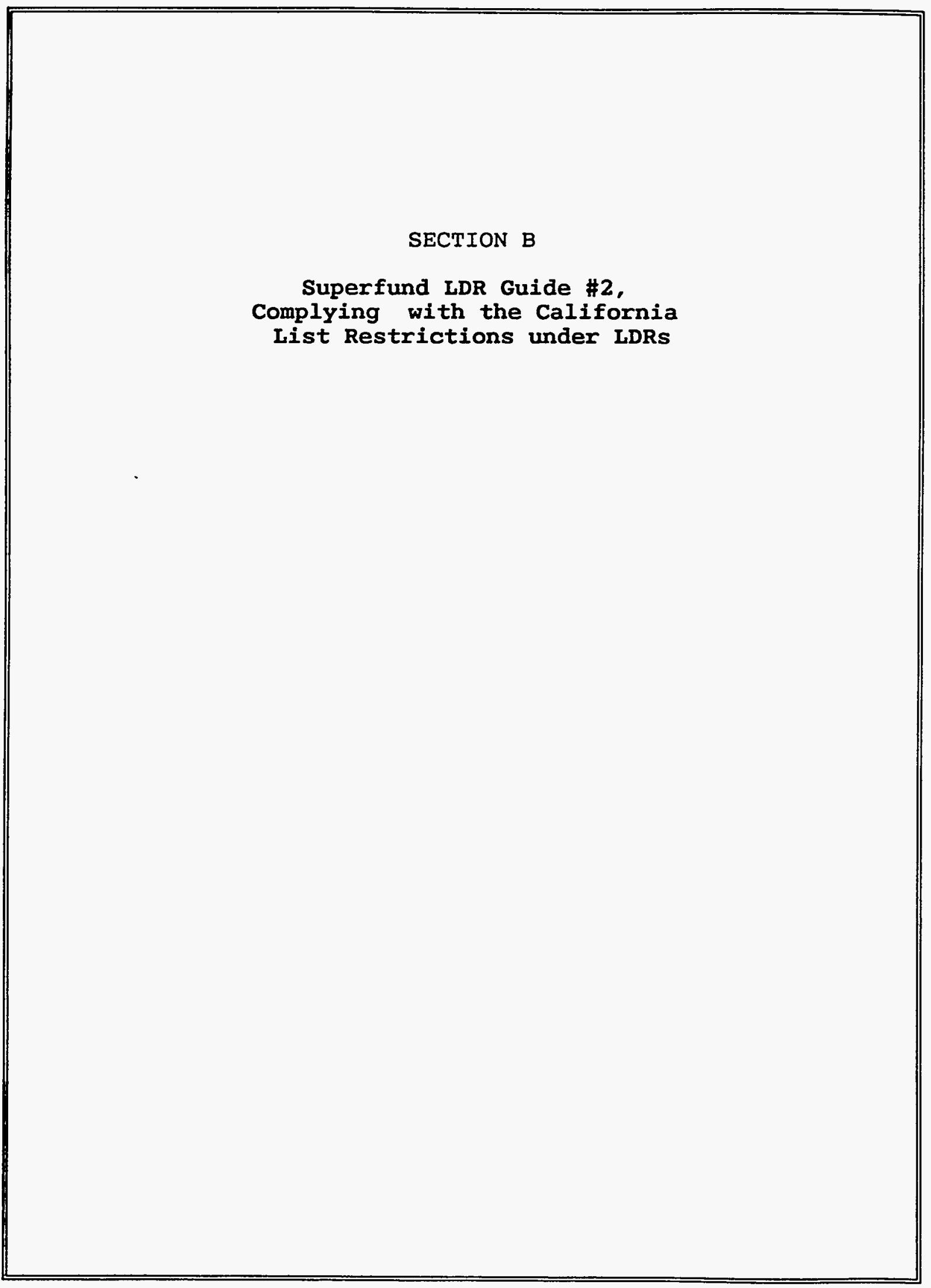


The Hazardous and Solid Waste Amendments (HSWA) to the Resource Conservation and Recovery Act (RCRA) include specific restrictions on the land disposal of RCRA hazardous wastes. California list wastes are a distinct category of RCRA hazardous wastes that ire restricted under the land disposal restrictions (LDRs). This guide defines the California list wastes, summarizes their respective restrictions, and discusses their potential overlap with other LDR treatment standards. More jetailed guidance on California list waste restrictions and ¿jperfund compliance with the LDRs is being prepared by the Office of Solid Waste and Emergency Response (OSWER).

\section{DEFINITION OF CALIFORNIA LIST WASTES}

To be classified as a California list waste, three conditions must be met:

(1) The waste must be a RCRA listed or characteristic waste;

(2) The waste must be a liquid (i.e., it fails method 9095 Paint Filter Liquids Test [PFLT]), except for Halogenated Organic Compounds (HOCs), which may be liquid or non-liquid; and

(3) The waste must exceed statutory prohibition levels for specified constituents.

The types of wastes that may be California list wastes are: free cyanides, certain metals, corrosive wastes, PCBs, and HOCs. (HOCs are compounds containing carbon and a halogen, such as fluorine, chlorine, bromine, iodine, and astatine, in their molecular formula). The Agency has limited the restricted HOCs to approximately 100 HOCs listed in Appendix III to 40 CFR Part 268. These restricted HOCs include solvents, pesticides, PCBs, and dioxins.

These hazardous wastes are referred to as California list wastes because the State of California developed regulations to restrict the land disposal of wastes containing these constituents, and Congress subsequently incorporated these provisions into the $1984 \mathrm{HSWA}$ amendments to RCRA. Even if LDR treatment standards have not been promulgated for certain RCRA wastes (e.g., Third Third wastes), these wastes may be subject to California list restrictions.
If the Agency has promulgated a treatment standard for a California list hazardous waste, the waste must attain that treatment standard before land disposal. If the Agency has not set a treatment standard the waste must be treated to below the prohibition level (or rendered non-liquid if a non-HOC waste) before it may be land disposed.

\section{CALIFORNIA LIST LDR RESTRICTIONS}

The Agency has promulgated treatment standards for PCB-containing wastes and HOC-containing wastes (except for dilute HOC wastewaters). The treatment standards for PCBs and some HOCs became effective on July 8, 1987.

The Agency has not set treatment standards for the remaining California list wastes. Instead, the Agency codified the statutory prohibition levels for corrosive wastes and dilute HOC wastewaters and allowed the hard hammer provisions to take effect for free cyanides and California list metals. The prohibitions on these wastes became effective on July 8,1987 . The effects of these restrictions are the sameprobihiting the land disposal of these wastes ahove the probibition levels.

Based on a finding of inadequate treatment capacity, EPA granted a nationwide extension to the effective date for treating California list HOC wastes until July 8, 1989. The Agency subsequently rescinded the variance, and the restriction for HOC wastes became effective November 8,1988 . The Agency also granted 
an extension of the effective date for HOC-containing soil and debris wastes until July 8, 1989, for soil and debris wastes not from CERCLA/RCRA corrective actions, and until November 8, 1990, for soil and debris wastes from CERCLA/RCRA corrective actions. California list wastes granted a national capacity variance from the treatment standards may be disposed of in a landfill or surface impoundment only if the receiving unit complies with minimum technology requirements (See Superfund LDR Guide \#3). The prohibition levels, treatment standards, and effective dates for the California list wastes are presented in Highlight 1.

\section{OVERLAP WTTH OTHER TREATMENT STANDARDS}

As noted earlier, wastes must be RCRA listed or characteristic wastes to be California list wastes. Therefore, California list wastes may also be restricted as solvent- or dioxin-containing wastes or as scheduled wastes. For wastes covered by more than one LDR standard, the LDR restrictions for the more specific waste stream generally take precedence, once the standard is promulgated. For example. FOO6 nonwastewaters may be restricted under the California list rule because the waste is a liquid and may contain nickel above the statutory prohibition level. The F006 treatment standard, which is expressed as a concentration level, however, takes precedence over the California list restriction (i.e., codified prohibition level).

The Agency has determined that soft hammer wastes and wastes for which national capacity variances have been granted remain subject to California list prohibitions (i.e., if either of these waste types is subject to a California list treatment standard or statutory prohibition level, that treatment standard or statutory level must be met before the waste can be land disposed). If a California list treatment standard is promulgated for a soft hammer waste, the more stringent of the restrictions apply. For example, if a non-liquid soft hammer waste contains $1,100 \mathrm{mg} / \mathrm{kg}$ total HOCs, the waste must meet the California list treatment standard of incineration or burning in a boiler or industrial furnace before land disposal. If a liquid soft hammer waste contains $510 \mathrm{mg} / \mathrm{l}$ lead (for which no California list treatment standard exists), the soft hammer restrictions apply. If treatment is not available, the waste must at least be treated below the prohibition level (i.e., $500 \mathrm{mg} / \mathrm{l}$ ) or rendered non-liquid and can only be disposed of in a surface impoundment or landfill if the receiving unit meets minimum technology requirements or has an equivalent waiver.

\section{Highlight 1 - PROHIBITION LEVELS AND TREATMENT STANDARDS}

FOR CALIFORNIA LIST WASTES

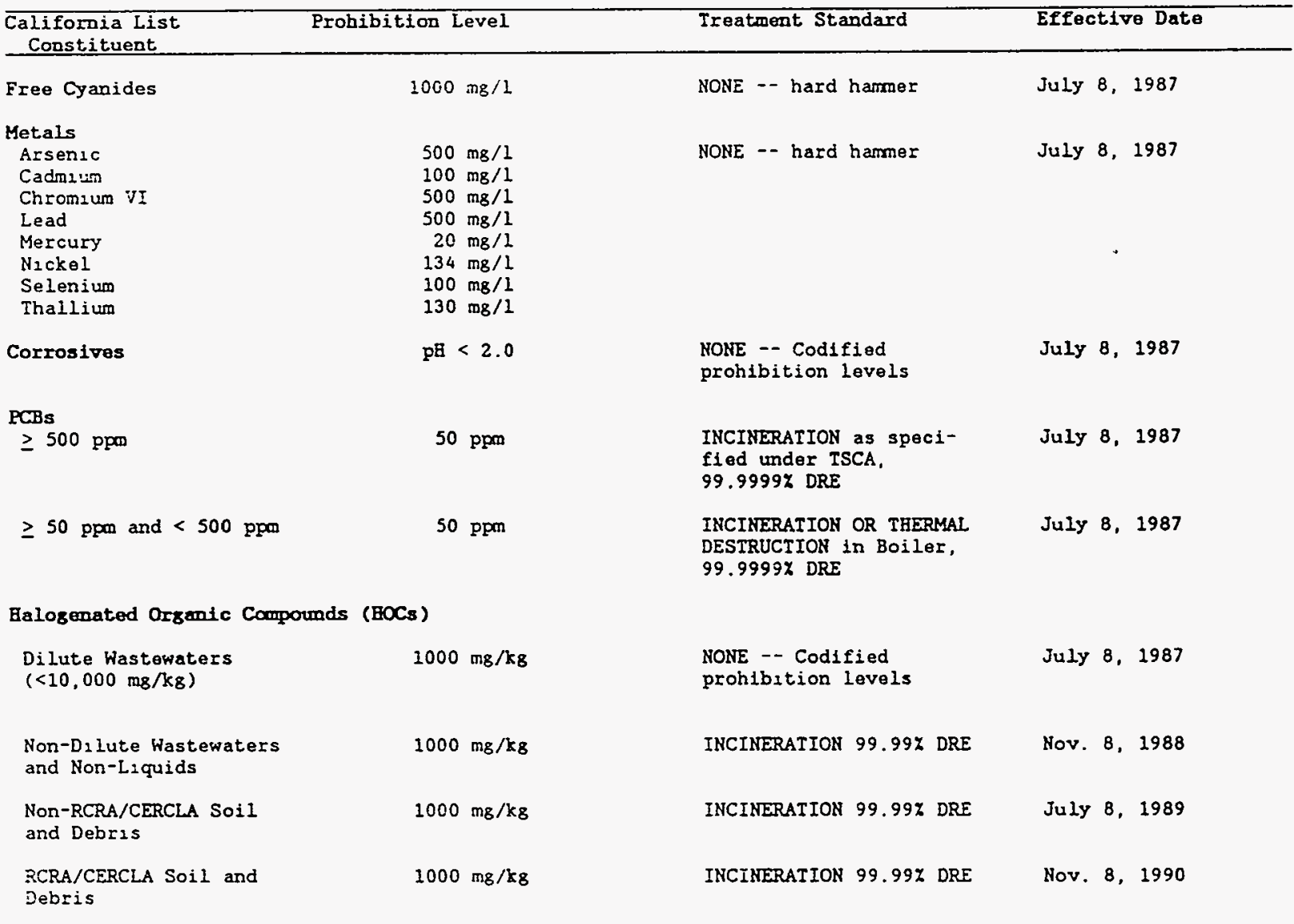




\section{SECTION C}

Superfund LDR Guide \#3,

Treatment Standards and

Minimum Technology Requirements under LDRs 


\section{United States \\ Treatment Standards and Minimum Technology Requirements Under Land Disposal Restrictions (LDRs)}

CERCLA section 121(d)(2) requires that Superfund response actions comply with other environmental laws that are applicable or relevant and appropriate requirements (ARARs). A potential ARAR for CERCLA responses is the Resource Conservation and Recovery Act (RCRA) land disposal restrictions (LDRs) established under the Hazardous and Solid Waste Amendments (HSWA). The LDRs prohibit the land disposal of restricted RCRA hazardous wastes unless these wastes meet treatment standards specified in 40 CFR Part 268, meet the minimum technology requirements during a national treatment capacity extension, or satisfy the requirements of one of the other available compliance options (i.e., Treatability Variance, Equivalent Treatment Method Petition, No Migration Petition, or Delisting). This guide summarizes the types and effective dates of treatment standards and outlines how to comply with the treatment standards and the minimum technology requirements set during national capacity extensions. More detailed guidance on Superfund compliance with the LDRs is being prepared by the Office of Solid Waste and Emergency Response (OSWER).

\section{TYPES OF TREATMENT STANDARDS}

EPA has established treatment standards under the LDRs on the basis of the best demonstrated available technology (BDAT) rather than risk-based or health-based standards. "Best" is defined as that technology which offers the greatest reduction (based on a statistical analysis) of toxicity, mobility, or volume of the waste. To be "demonstrated," a treatment technology must be demonstrated to work at a fullscale level (i.e., technologies available only on a pilotor bench-scale are not considered demonstrated). To be "available," a treatment technology must be commercially available.

Within this framework, the Agency has established three types of LDR treatment standards:

- Concentration levels -- which must be attained before the wastes or treatment residuals may be land disposed;

- Specified technologies -- which must be applied to the waste before the residuals may be land disposed; and

- No land disposal -- which prohibits land disposal of certain restricted hazardous wastes.

\section{Concentration Levels}

The majority of the LDR treatment standards promulgated to date are concentration levels. For wastes with treatment standards expressed as concentrations, any technology that can achieve the required levels may be used unless the technology is otherwise prohibited (i.e., the BDAT used by EPA to set the standards need not be used).

To establish a concentration level(s) for a specific waste code (e.g., K062), the Agency selects a subset of the hazardous constituents found. in the waste (known as "BDAT constituents") and sets treatment standards for each of these constiments. Although these wastes may contain additional constituents, only the treatment standards for the "BDAT constituents" must be met before the wastes can be land disposed. The residues from treatment of an originally listed waste (e.g., ash, scrubber water) are also listed RCRA hazardous wastes (because of the "derived from" rule), and therefore, also are prohibited from land disposal unless they meet treatment standards for the waste code(s) of the original listed waste(s) from which they derive.

EPA has promulgated separate standards for wastewaters and nonwastewaters for treatment standards expressed as concentration levels. For LDRs, wastewaters normally are defined as wastes containing less than one percent total organic carbon (TOC) and lisis than one percent total suspended solids. All other materials (including soil and debris) are classified as nonwastewaters, except for F001-F005 wastes, for which only the TOC is used to define wastewaters.

Concentrations of BDAT constituents in solid residues from treatment must not exceed the 
nonwastewater concentrations. Similarly, the concentration of BDAT constituents in wastewaters from treatment (e.g. incineration scrubber water) must not exceed the wastewater concentrations. Highlight 1 provides an example of standards expressed as concentration levels for K062 waste.

\begin{tabular}{|c|c|c|}
\hline \multicolumn{3}{|c|}{$\begin{array}{l}\text { Highlight } 1 \text { - TREATMENT } \\
\text { STANDARDS FOR K062 WASTE }\end{array}$} \\
\hline Constituent & $\begin{array}{l}\text { Treatment } \\
\text { Total Waste } \\
(\mathrm{mg} / \mathrm{kg})\end{array}$ & $\begin{array}{r}\text { Standard } \\
\text { TCLP } \\
(\mathrm{mg} / 1) \\
\end{array}$ \\
\hline $\begin{array}{l}\text { Nonwastewater } \\
\text { Total chromium } \\
\text { Lead }\end{array}$ & $\begin{array}{l}\stackrel{.}{A} \\
\therefore A\end{array}$ & $\begin{array}{l}0.094 \\
0.37\end{array}$ \\
\hline $\begin{array}{l}\text { Wastewater } \\
\text { Total chromium } \\
\text { Nickel } \\
\text { Lead }\end{array}$ & $\begin{array}{l}0.32 \\
0.44 \\
0.04\end{array}$ & $\begin{array}{l}\mathrm{NA} \\
\mathrm{NA}\end{array}$ \\
\hline $\begin{array}{l}\text { * K062 waste is spe } \\
\text { the steel finishing } \\
\text { within the iron a }\end{array}$ & $\begin{array}{l}\text { ickle liquor } \\
\text { rations of fa } \\
\text { eel industry. }\end{array}$ & $\begin{array}{l}\text { generated b } \\
\text { acilities }\end{array}$ \\
\hline
\end{tabular}

\section{Specified Technologies}

If a treatment standard is promulgated as a specified technology, that technology must be used to treat the waste unless an Equivalent Treatment Method Petition is approved by the Administrator. To be granted, such a petition must demonstrate that the alternative technology achieves an equivalent measure of performance. For example, the Agency has set the treatment standard for California list PCB wastes containing greater than $500 \mathrm{ppm}$ PCBs as thermal destruction. These wastes must be incinerated to 99.9999 percent destruction and removal efficiency (DRE) under the LDRs before the ash from treatment may be land disposed unless a Petition allowing an equivalent treatment method is granted.

\section{No Land Disposal}

EPA sets a standard of no land disposal when, after examining available data, the Agency has determined that: the waste can be totally recycled (e.g., on-site, closed loop recycling); the waste is not currently being land disposed; the waste is no longer generated; or no residuals are anticipated from the use of the BDAT.

Although certain wastes may no longer be generated or land disposed, these wastes may still be found at Superfund sites. EPA has amended most of these waste codes, however, to apply only to wastes generated from the process described in the listing description and disposed of after the effective date of the prohibition (see 54 FR 18836, May 2, 1989). Therefore, CERCLA wastes ordinarily would not be subject to these standards.

\section{COMPLYING WTH LDR TREATMENT STANDARDS}

There are two types of tests for evaluating compliance that may be required, depending on how the treatment standards are promulgated: the Total Waste Analysis (TWA) measures the total concentration levels of the hazardous constituents in the waste or treatment residuals; and the Toxicity Characteristic Leaching Procedure (TCLP) measures concentration levels in the waste extract as a result of the TCLP test.

The TWA test generally is used for organic constituents when a removal or destruction technology is the BDAT. The TCLP generally is used for inorganics when an immobilization BDAT is the basis for the standard. However, the TCLP is also used for the solvent- and dioxin-containing waste LDR treatment standards and TWA is used for metals when BDAT is based on metals recovery. Site managers (OSCs and RPMs for on-site treatment and disposal actions) or treatment facilities (for off-site disposal actions) must test wastes after treatment and before land disposal to determine if the LDR treatment standards are met.

\section{TREATMENT STANDARDS IN EFFECT FOR RCRA HAZARDOUS WASTES}

Once a determination that the LDRs are ARARs has been made (see Superfund LDR guide \#5), site managers must determine which of the specific LDR restrictions are in effect for their waste(s) of concern. If the Agency has promulgated a treatment standard for a restricted RCRA hazardous waste, either the LDR treatment standards or the minimum technology requirements will be in effect. If EPA has not set a treatment standard for a restricted RCRA hazardous waste, either the soft or hard hammer provisions will be in effect (see Superfund LDR Guide \#4). The Agency has promulgated treatment standards for the following wastes:

\section{Solvent-Containing RCRA Hazardous Wastes}

For solvent-containing RCRA hazardous wastes (F001-F005), EPA has promulgated treatment standards expressed as concentration levels. Unlike most of the treatment standards for wastes containing organic constituents, the standards for the F001-F005 wastes are expressed as TCLP concentrations (40 CFR 268.41). 


\section{Dioxin-Containing RCRA Hazardous Wastes}

Dioxin-containing wastes (F020-F023 and F026FO28); include chlorinated dibenzo-p-dioxins (CDDs), chlorinated dibenzofurans (CDFs), and chlorophenols. The treatment standards expressed as concentration levels are based on incineration of contaminated soil. Because current analytical methods cannot measure the concentration levels attainable by the BDAT, EPA set the treatment standards at the practical detection limits (i.e., $1 \mathrm{ppb}$ ) for most wastes. These standards are also based on a TCLP analysis (40 CFR 268.41).

Although the LDR treatment standards for dioxincontaining wastes are concentration levels. the dioxinlisting rule (50 FR 1978) requires special management standards for certain types of units:

- Incineration in accordance with 40 CFR 264.343 and 40 CFR 265.352;

- Thermal treatment to 99.9999 percent DRE in accordance with 40 CFR 265.383; or

- Tank treatment, in accordance with 40 CFR 264.200 .

Highlight 2 describes the LDR restrictions in effect for solvent- and dioxin-containing RCRA hazardous wastes.

\section{California List Hazardous Wastes}

The California list rule established specified technologies as the treatment standards for certain California list wastes. Specifically, California list PCB and halogenated organic compound (HOC) wastes (except dilute HOC wastewaters) must be incinerated or burned in high-efficiency boilers or industrial furnaces. Highlight 3 provides the LDR restrictions in effect for California list wastes.

\section{First Third Wastes}

The First Third scheduled wastes include those listed wastes that are intrinsically hazardous or are high-volume wastes. EPA promulgated treatment standards expressed as concentration levels and no land disposal based on TWA and TCLP for certain First Third wastes on August 17, 1988. First Third wastes that do not have promulgated treatment standards are restricted under the "soft hammer" provisions. Highlight 4 describes the LDR restrictions in effect for certain First Third wastes for which the Agency has set treatment standards.

\section{MINLMUM TECHNOLOGY REQUIREMIENTS THAT APPLY DURING A NATIONAL CAPACITY EXTENSION}

If during the promulgation of treatment standards the Agency determines that insufficient treatment capacity exists, the Agency may grant a national capacity extension for a period of up to two years. During the extension period, if wastes are to be land disposed in surface impoundments or landfills, the units must comply with the RCRA Subtitle $C$ minimum technology requirements (i.e., double liner, leachate collection system, and ground-water monitoring) under RCRA $3005(j)(2)$ or (j)(4) or the receiving units must have a retrofitting waiver under RCRA 3004(o)(2) or $3005(j)$ to be considered equivalent to the minimum technology requirements.

\section{Highlight 2 - EFFECTIVE DATES AND LDR RESTRICTIONS FOR SOLIENTS AND DIOXINS}

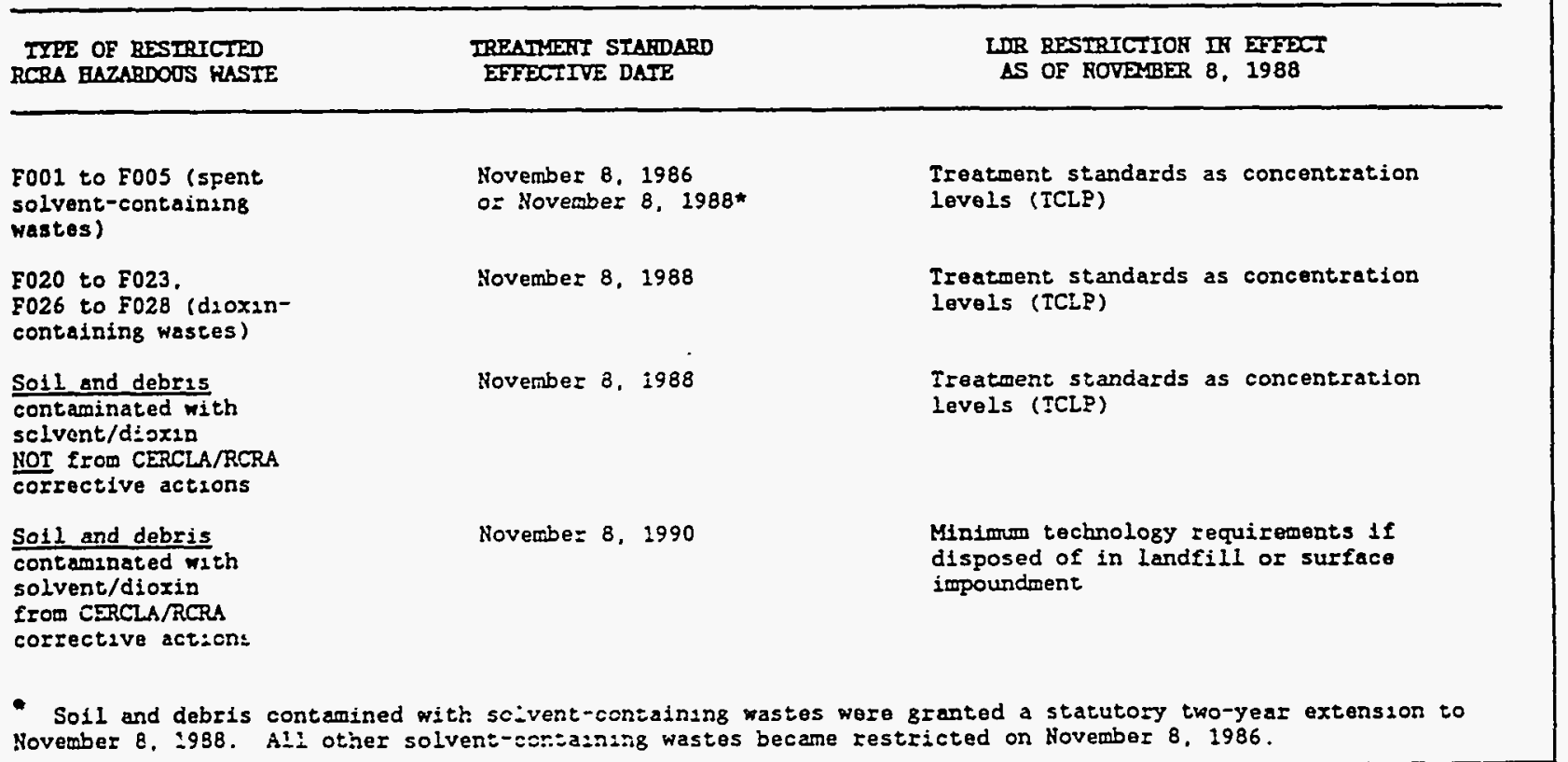


Highlight 3 - EFFECTIVE DATES AND LDR RESTRICTIONS FOR CALIFORNIA LIST WASTES ${ }^{a /}$

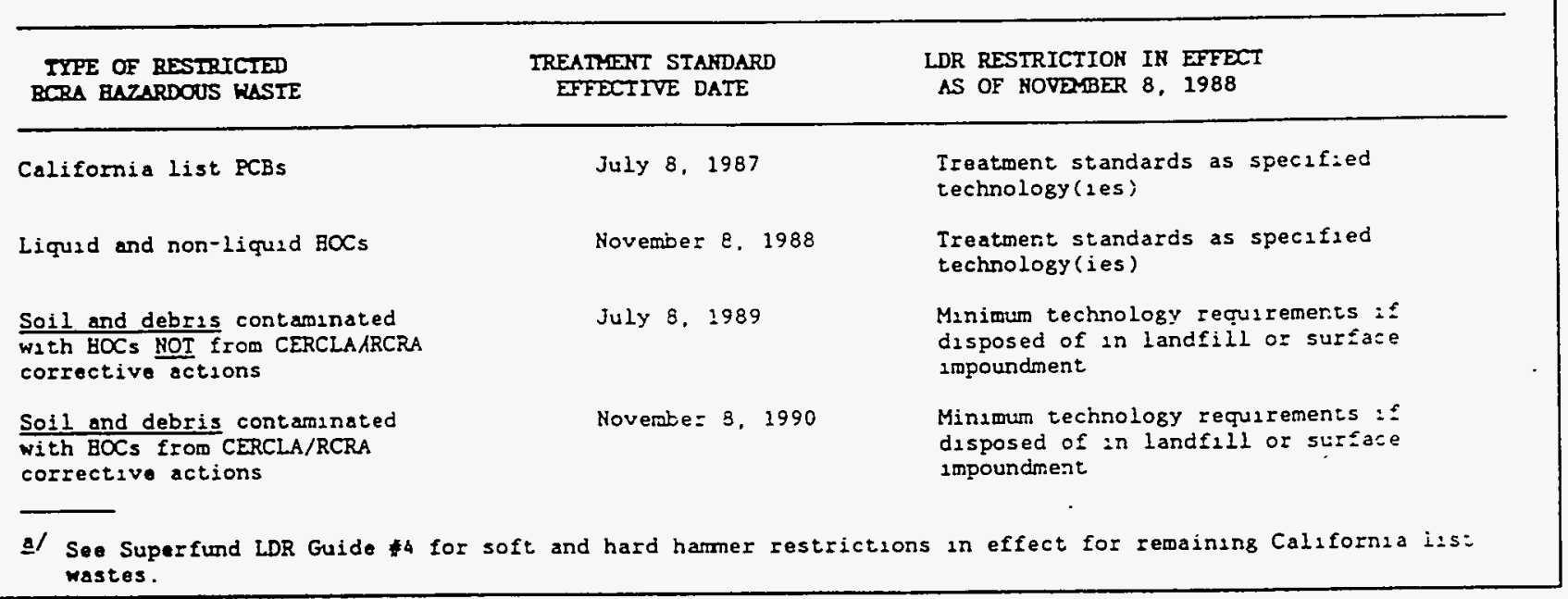

National capacity extensions for several types of wastes currently are in effect under the LDRs. For example, soil and debris from CERCLA and RCRA corrective actions that are contaminated with solvent, dioxin, and California list wastes have received an extension until November 8,1990. All soil and debris contaminated with First Third wastes for which the
BDAT is based on solids incineration have received an extension until August 8, 1990 . Land disposal of wastes subject to national capacity extensions in units other than surface impoundments and landfills (e.g., waste piles, land treatment units) is not subject to the minimum technology requirements during such an extension.

\section{WASTES $^{\mathrm{a} / \mathrm{C}}$ \\ Highlight 4 - EFFECTIVE DATES AND LDR RESTRICTIONS FOR CERTAIN FIRST THIRD}

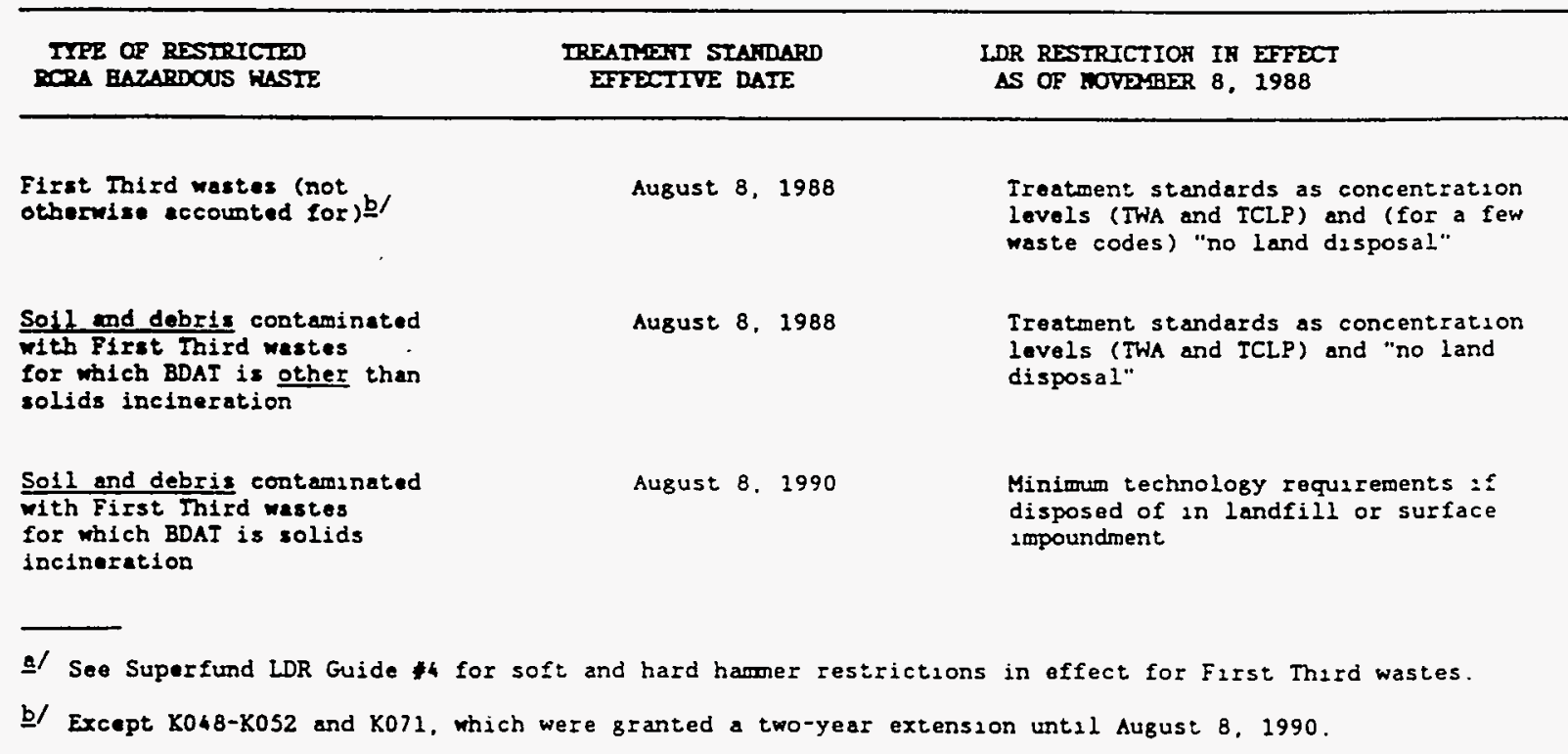




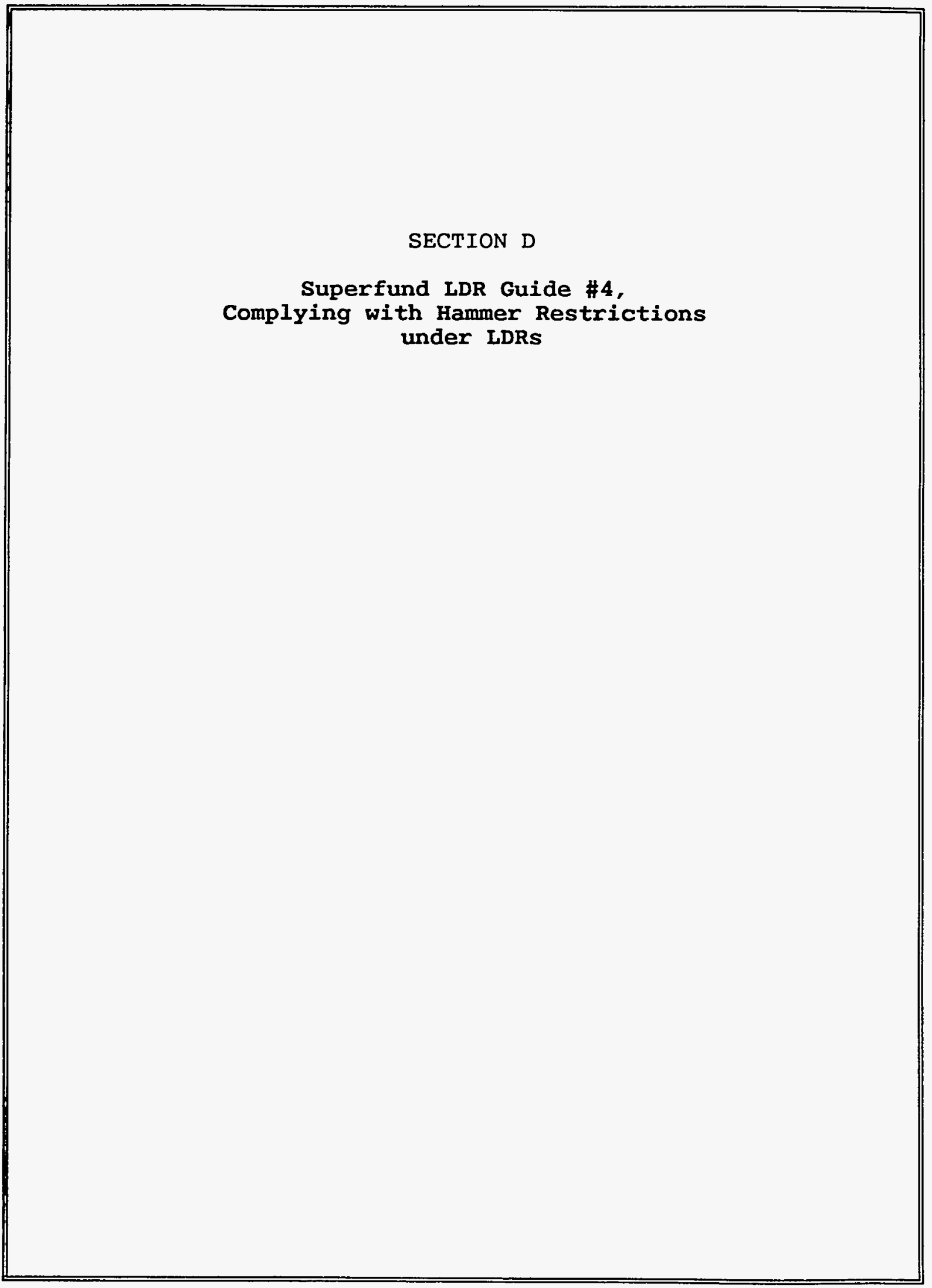




\section{United States \\ Environmental Protection \\ Orice of Agency \\ Solid Waste and \\ 9347.3-O4FS \\ Emergency Response \\ July 1989 \\ Superfund LDR Guide \#4 \\ Complying With the Hammer Restrictions Under Land Disposal Restrictions (LDRs)}

Supertund Publication:

CERCLA response actions must comply with the Resource Conservation and Recovery Act (RCRA) Land Disposal Restrictions (LDRs) when they are determined to be applicable or relevant and appropriate requirements (ARARs). Compliance with the LDRs will involve meeting the LDR treatment standards, minimum technology requirements during a national capacity extension, the soft or hard hammer restrictions, or satisfying the requirements of one of the other LDR compliance options (i.e., Treatability Variance, Equivalent Treatment Method Petition, No Migration Petition or Delisting). This guide discusses complying with LDR soft hammer and hard hammer provisions, which are restrictions on the disposal of hazardous wastes if EPA does not promulgate standards by the statutory deadlines. More detailed guidance on Superfund compliance with the LDRs is being prepared by the Office of Solid Waste and Emergency Response (OSWER).

\section{SOFT HAMMER WASTES}

If the Agency fails to set treatment standards for First or Second Third wastes by their specified statutory deadline (August 8, 1988, and June 8, 1989, respectively), the wastes become restricted under the soft hammer provisions until EPA sets a treatment standard for them, or until May 8,1990, when the "hard hammer" provisions will fall. The soft hammer provisions specify certain restrictions that may have to be met before the wastes can be land disposed. The hard hammer provisions prohibit all land disposal of the wastes. Highlight 1 lists $\mathrm{F}$ - and $\mathrm{K}$-wastes that are soft hammer wastes (as of June 8, 1989).

\section{Soft Hammer Restrictions}

The LDR soft hammer provisions prohibit the disposal of wastes in surface impoundment or landfill units unless:

(1) The receiving unit meets the RCRA minimum technology requirements (i.e., the unit must have two or more liners, a leachate collection system, and a ground-water monitoring system) or have an equivalent RCRA retrofitting "waiver. These waivers are described in RCRA $\$ 3005(j)(2)$, which requires that a unit be at least one-quarter of a mile from an underground drinking source, and

Highlight 1 - F and $\mathrm{K}$ SOFT HAMMER WASTES (as of June 8, 1989)

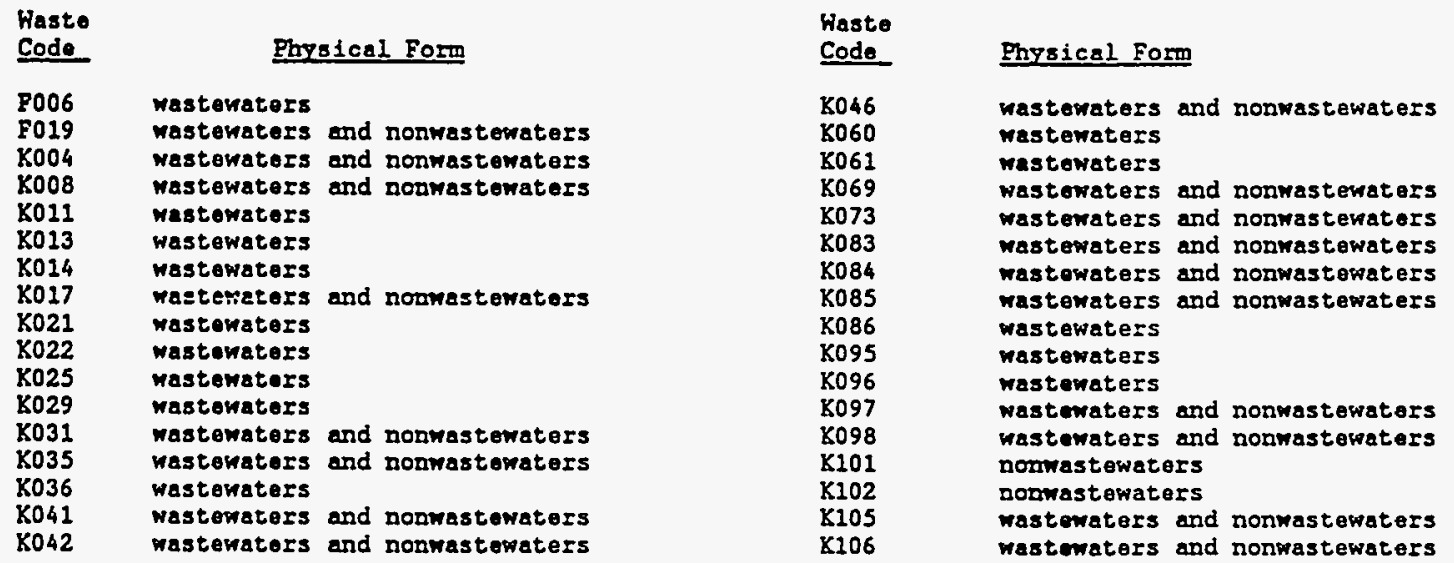

\footnotetext{
* For a complete listing of soft bemer waste restrictions, including all $P$ and $U$ wastes thet are restricted. consult with EPA Eeadquarters.
} 
RCRA $\$ 3005(j)(4)$, which requires that the unit be designed and operated such that there will be no migration of hazardous constituents into ground or surface water.

Waivers granted to units utilizing aggressive biological treatment (RCRA $\$ 3005(j)(3)$ ) or undergoing corrective action (RCRA \$3005(j)(13)) are not automatically considered equivalent to units in compliance with the minimum technology requirements. However, they may satisfy the $\$ 3004(0)$ (2) equivalency standard on a unit-by-unit basis.

(2) Site managers (OSCs, RPMs) certify that they have made a good faith effort to locate and to contract with treatment and recovery facilities for treatment that is "practically available." If such treatment is "practically available," the manager must use the best, practically available treatment (see Highlight 2 ) to treat the wastes before they are land disposed. If there is no "practically available" treatment, the soft hammer wastes may be disposed of without treatment in units meeting the requirements listed in (1).

Highlight 2 - GUIDE TO "PRACTICALLY AVAILABLE" AND "BEST" TREATMENT

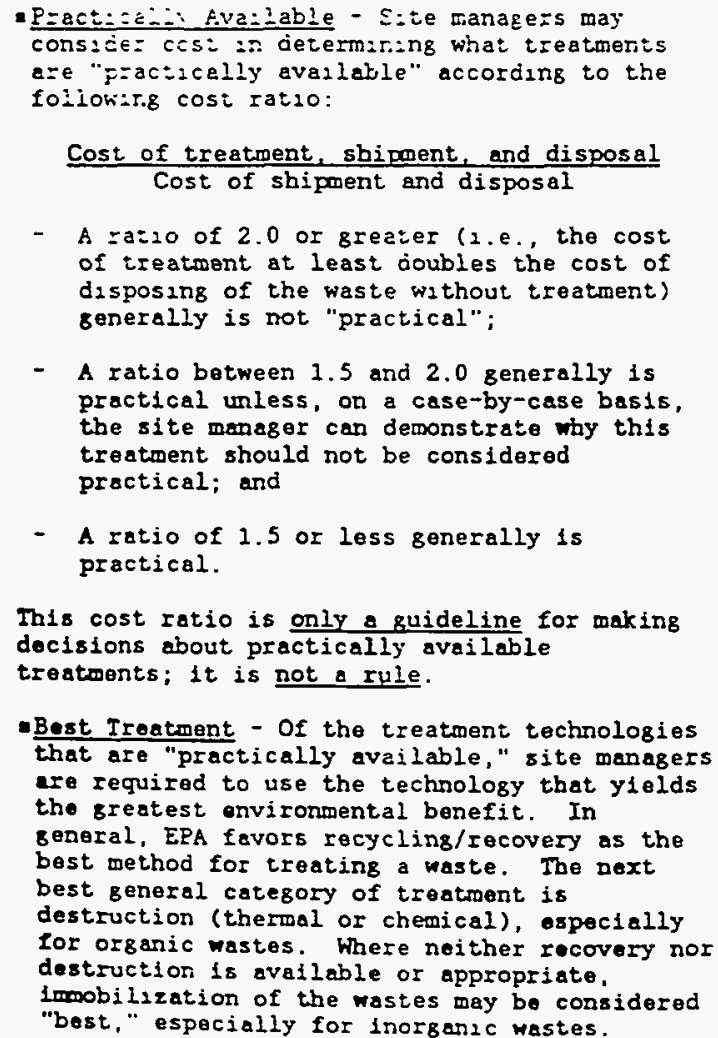

- A ratio between 1.5 and 2.0 generally is practical unless, on a case-by-case basis, the site manager can demonstrate why this treatment should not be considered proctical; and

- A ratio of 1.5 or less senerally is practical.

This cost ratio is only a guideline for making docisions bout practically available

treatoents; it is not a rule.

Best Ireatment - of the treatment technologies that are "practically available," site managers are required to use the technology that yields the greatest environmental benefit. In general. EPA fevors recycling/recovery as the best wethod for treating a waste. The pext

best general catesory of treatment is

destruction (thermal or chemical), especially for organic wastes. Where neither recovery nor destruction is available or appropriate. imobilization of the wastes may bo considered

"best." especially for inorgarlc rastes.

Soft hammer wastes disposed of in units other than surface impoundments or landfills do not have to meet the soft hammer restrictions before land disposal. However, these wastes must comply with the LDR notification requirements and other LDR restrictions, such as storage prohibition. (The storage prohibition restricts the storage of soft hammer wastes unless it is solely for the purpose of accumulating sufficient quantities to facilitate proper treatment, recovery, or disposal.)

\section{Soft Hammer Requirements for Notifications, Certifications, and Demonstrations}

When soft hammer wastes are land disposed or treated off-site, site managers must comply with the LDR notification, certification, and demonstration requirements. When treatment and land disposal occur on-site, site managers must only meet the demonstration requirements. (The notification and certification requirements are administrative requirements and do not have to be met for on-site actions.) The specific notification requirements, including to whom and when they must be sent and the required language from 40 CFR Part 268, are shown in Highlight 3 for each of these categories.

\section{California List and Soft Hammer Overlap}

Certain sof hammer wastes also may be California list wastes. in which case they may be subject either to the California list or soft hammer requirements. If a waste is restricted by soft hammer and California list restrictions, site managers should meet the more stringent standard for the waste.

- If treatment standards have been promulgated for a California list waste that is also a soft hammer, the California list treatment standard must be met for the waste before it is land disposed of into any type of unit. In this case, the soft hammer restrictions and notification, certification, and demonstration requirements do not apply.

a If treatment standards have not been promulgated for a California list waste that is also a soft hammer, and the waste is to be land disposed in a surface impoundment or landfill, one of two situations may arise:

(1) If treatment is "practically available," a site manager must use the "best" treatment to meet the soft hammer requirements.

(2) If treatment is not "practically available," the waste still must, at a minimum, be treated to below the California list prohibition levels before being land disposed to satisfy the California list restrictions. 


\section{Highlight 3 - SOFT HAMMER NOTIFICATION, CERTIFICATION, AND DEMONSTRATION REQUIREMENTS}

\begin{tabular}{|c|c|c|c|}
\hline REQUIPRPDITI & SETIT TO & Hater & REQOIRED IRFOMAIIOA \\
\hline $\begin{array}{l}\text { NOTIFICATION } \\
\text { (off-site only) }\end{array}$ & $\begin{array}{l}\text { Treatment or } \\
\text { disposal } \\
\text { facility } \\
\text { receiving } \\
\text { waste }\end{array}$ & $\begin{array}{l}\text { With each } \\
\text { waste } \\
\text { shipoent }\end{array}$ & $\begin{array}{l}\text { Notification that the waste is a soft hamor } \\
\text { waste. Specific information includes: } \\
\text { - EPA hazardous waste number; } \\
\text { - Any applicable prohibitions (e.g., soft } \\
\text { hamer provision); } \\
\text { - Manifest number associated with shipment of } \\
\text { waste; and }\end{array}$ \\
\hline
\end{tabular}

$\begin{array}{lll}\text { CERIFICA:ICN - } & \text { EPA Regioral } & \text { At ime of } \\ \text { If treatment is } & \text { Adninistrator } & \text { first waste } \\ \text { not practically } & \text { and } & \text { shipwent and } \\ \text { available } & \text { Disposal } & \text { copy with } \\ \text { (off-site only) } & \text { Eaility } & \text { each waste } \\ & \text { receiving } & \text { shipment } \\ & \text { waste } & \end{array}$

Certlfication should appear as follows:

"EPA certifies under penalty of law that the requirements of 40 CFR 268.8 (a)(1) have beer. Tet and that disposal in a landfill or surface impoundment is the only practical alternat: $\because e$ : 0 treatment currently available. EPA beizeves isat the information submitted is true, accusate and complete, EPA is aware that there are $\$ i g::=:$ cant penaities for submitting false informatior. including the possibility of fine and imprisonment.

$\begin{array}{lll}\text { CERTIFICAIION - } & \text { EPA Regional } & \text { At time of } \\ \text { If treatment is } & \text { Administrator } & \text { first waste } \\ \text { practically } & \text { and } & \text { shipment and } \\ \text { available } & \text { Ireatment } & \text { copy with } \\ \text { (off-site only) } & \text { facility } & \text { each waste } \\ & \text { receiving } & \text { shipment } \\ & \text { waste } & \end{array}$

Certification should appear as follows:

"EPA certifies under penalty of law that the requizements of 40 CFR 268.8(a)(1) have been met and that the agency has contracted so treat its waste (or will otherwise provide treatmen:) by the practically available technology which yields the greatest environmental benefit, as indicated in its demonstration. EPA belleves that the information submitted is true, accurate, and complete. EPA is aware that there are significant penalties for submitting false information. includins the possibility of fine and imprisonment."

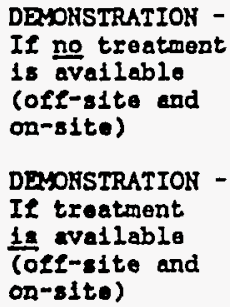

\section{EPA Regional Administrator \\ At time of first waste shipoent}

EPA Regional Administrator

At time of first raste shipoent
List of facilities and factlity officials contacted, addresses, telephone numbers, and contact dates. Also, aritten discussion of when treatment or recovery is not practical for the waste.

List of facilities and facility officials contacted, addresses, telephone numbers, and contact dates. Provide information on the chosen treatment technology selected because it provides the greatest emvironmental benefit
In both cases, site managers must meet the appropriate soft hammer notification, certification, and demonstration requirements.

If the waste will be land disposed in a unit other than a surface impoundment or landfill (e.g., waste pile), the waste must, at a minimum, be treated below the California list prohibition level before being land disposed. The soft hammer restrictions do not apply, and a site manager does not have to meet the soft hammer notification, certification, and demonstration requirements.

More information on California list wastes and their overlap with soft hammer wastes is found in LDR Guide \#2. A step-by-step process to comply with the soft hammer restrictions is shown in Highlight 4 . 


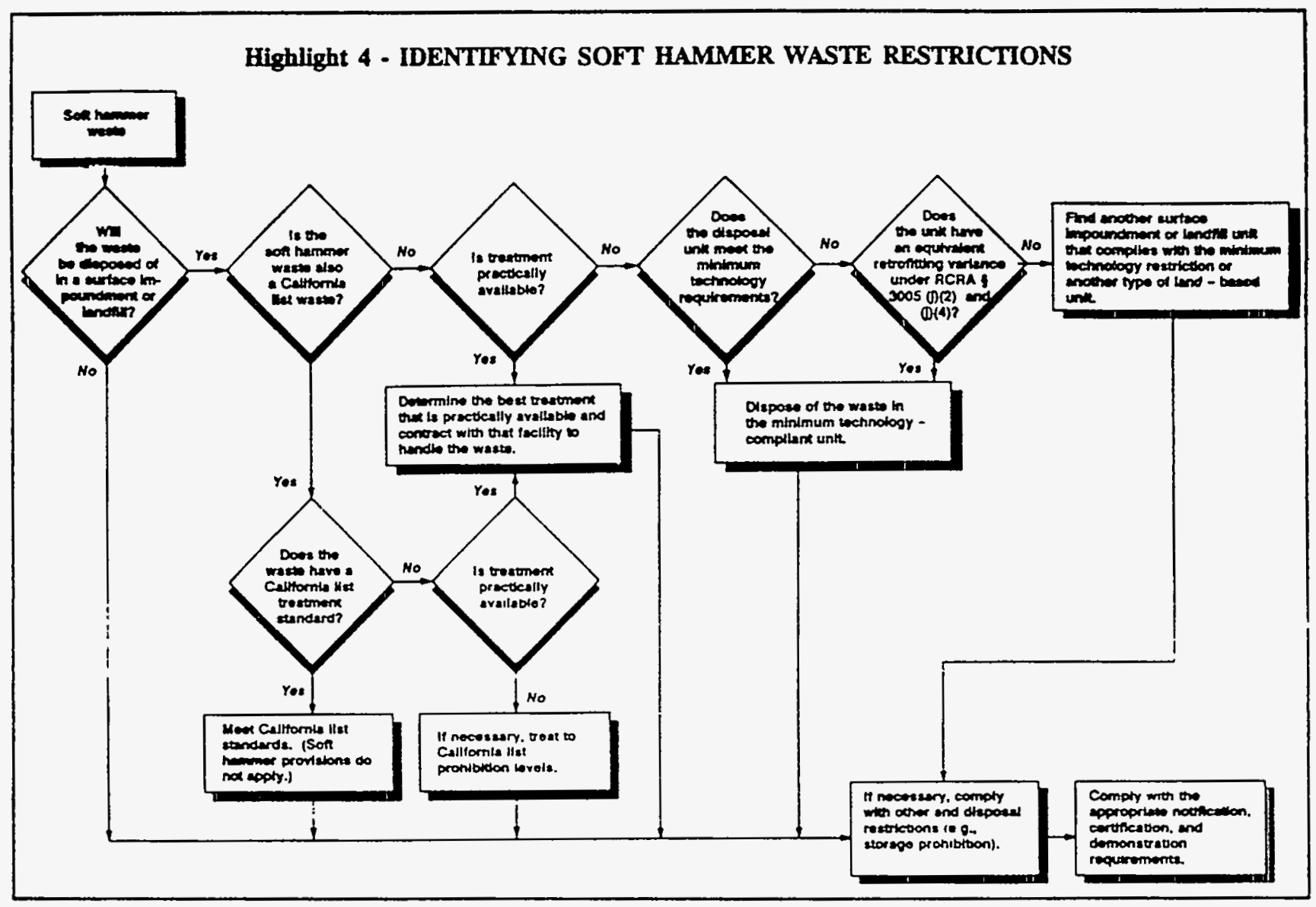

\section{HARD HAMMER WASTES}

The hard hammer provisions prohibit land disposal of restricted wastes if EPA fails to promulgate treatment standards by the statutory deadlines for solvent- and dioxin-containing and California list wastes and by May 8, 1990, for all of the scheduled wastes. The deadlines for these wastes are shown in Highlight 5. At present, the hard hammer provisions have only fallen for California list cyanides and metals. EPA has also codified statutory prohibition levels for California list corrosive wastes and dilute HOC wastewaters. Codification of the prohibition levels has the same effect as letting the hard hammer fall: land disposal of these wastes is prohibited when wastes are found in concentrations above the prohibition levels.

There are only two exceptions to the prohibition on land disposal of the hard hammer wastes: delisting and a No-Migration Petition. Delisting is a general option for demonstrating that a listed waste is no longer hazardous that is available under RCRA $\$ 260.20$ and $\$ 260.22$. The process to obtain No-Migration Petitions is specified in RCRA \$268.6. To obtain a Petition, disposal facilities demonstrate that there will be no migration of hazardous constituents from the disposal unit or injection zone for as long as the waste remains hazardous. This is a rulemaking petition and is expected to require extensive documentation.
Highlight 5: HARD HAMMER DEADLINES

Waste $\quad \begin{gathered}\text { Hard Hammer } \\ \text { Deadline }\end{gathered}$

Solvent \&

November 8, 1986

dioxin wastes

California

July 8, 1987

list wastes

CERCLA/RCRA

November 8, 1988

corrective action

soil and debris

contaminated with

solvent and dioxin

and California

list wastes

Scheduled wastes

(1st Third, 2nd

May 8, 1990

Third, and 3rd

Third wastes) 


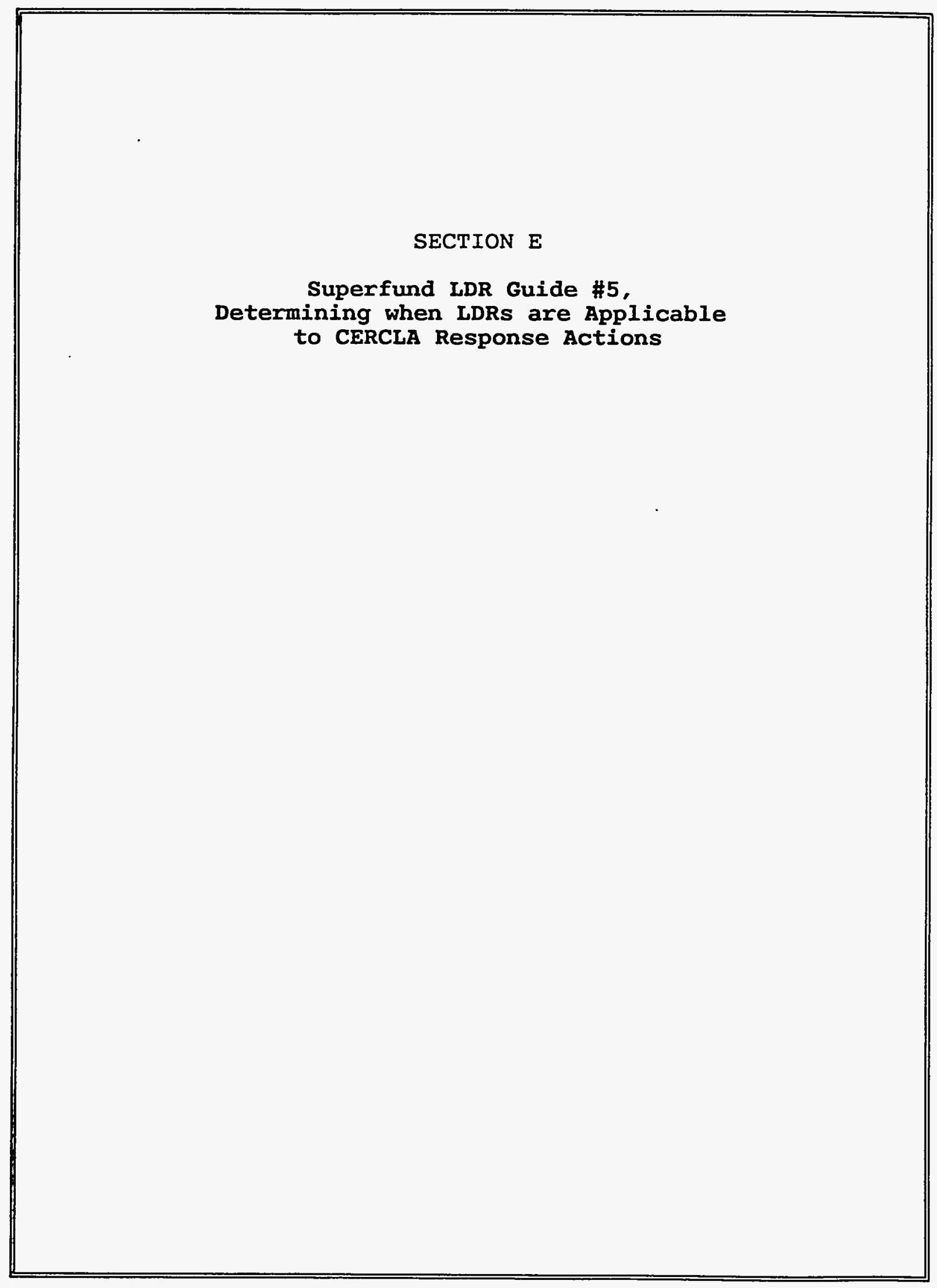




\section{Determining When Land Disposal Restrictions (LDRs) Are Applicable to CERCLA Response Actions}

CERCLA Section 121(d)(2) specifies that on-site Superfund remedial actions shall attain "other Federal standards, requirements, criteria, limitations, or more stringent State requirements that are determined to be legally applicable or relevant and appropriate (ARAR) to the specified circumstances at the site." In addition, the National Contingency Plan (NCP) requires that on-site removal actions attain ARARs to the extent practicable. Qff-site removal and remedial actions must comply with legally applicable requirements. This guide outilines the process used to determine whether the Resource Conservation and Recovery Act (RCRA) land disposal restrictions (LDRs) established under the Hazardous and Solid Waste Amendments (HSWA) are "applicable" to a CERCLA response action. More detailed guidance on Superfund compliance with the LDRs is being prepared by the Office of Solid Waste and Emergency Response (OSWER).

For the LDRs to be applicable to a CERCLA response, the action must constitute placement of a restricted RCRA hazardous waste. Therefore, site managers (OSCs, RPMs) must answer three separate questions to determine if the LDRs are applicable:

(1) Does the response action constitute placement?

(2) Is the CERCLA substance being placed also a RCRA hazardous waste? and if so

(3) Is the RCRA waste restricted under the LDRs?

Site managers also must determine if the CERCLA substances are California list wastes, which are a distinct category of RCRA hazardous wastes restricted under the LDRs (see Superfund LDR Guide \#2).

\section{(1) DOES THE RESPONSE CONSTITUTE PLACEMENT?}

The LDRs place specific restrictions (e.g., treatment of waste to concentration levels) on RCRA hazardous wastes prior to their placement in land disposal units. Therefore, a key a $\quad$ a is whether the response action will constitute placement of wastes into a land disposal unit. As defined by RCRA, land disposal units include landfills, surface impoundments, waste piles, injection wells, land treatment facilities, salt dome formations, underground mines or caves, and concrete bunkers or vaults. If a CERCLA response includes disposal of wastes in any of these types of off-site land disposal units, placement will occur. However, uncontrolled hazardous waste sites often have widespread and dispersed contamination, making the concept of a RCRA unit less useful for actions involving on-site disposal of wastes. Therefore, to assist in defining when "placement" does and does not occur for CERCLA actions involving on-site disposal of wastes, EPA uses the concept of "areas of contamination" (AOCs), which may be viewed as equivalent to RCRA units, for the purposes of LDR applicability determinations.

An AOC is delineated by the areal extent (or boundary) of contiguous contamination. Such contamination must be continuous, but may contain varying types and concentrations of hazardous substances. Depending on site characteristics, one or more AOCs may be delineated. Highlight 1 provides some examples of AOCs.

\section{Highlight 1: EXAMPLES OF AREAS OF CONTAMINATION (AOCs)}

- A waste source (e.g., waste pit, landfill, waste pile) and the surrounding contaminated soil.

- A waste source, and the sediments in a stream contaminated by the source, where the contamination is continuous from the source to the sediments. ${ }^{*}$

- Several lagoons separated only by dikes, where the dikes are contaminated and the lagoons share a common liner.

- The $A O C$ does not include any contaminated surface or ground water that may be associated with the landbased waste source. 
For on-site disposal, placement occurs when wastes are moved from one AOC (or unit) into another AOC (or unit). Placement does not occur when wastes are left in place, or moved within a single AOC. Highlight 2 provides scenarios of when placement does and does not occur, as defined in the proposed NCP. The Agency is current reevaluating the definition of placement prior to the promulgation of the final NCP, and therefore, these scenarios are subject to change.

\section{Highlight 2: PLACEMENT}

Placement does occur when wastes are:

- Consolidated from different $A O C$ s into a single $A O C$;

- Moved outside of an AOC (for treatment or storage, for example) and returned to the same or a different $A O C$; or

- Excavated from an $A O C$, placed in a separate unit, such as an incinerator or tank that is within the $A O C$, and redeposited into the same AOC.

Placement does not occur when wastes are:

- Treated in situ;

- Capped in place;

- Consolidated within the AOC; or

- Processed within the AOC (but not in a separate unit, such as a tank) to improve its structural stability (e.g., for capping or to support heavy machinery).

In summary, if placement on-site or off-site does not occur, the LDRs are not applicable to the Superfund action.

\section{(2) IS THE CERCLA SUBSTANCE A RCRA HAZARDOUS WASTE?}

Because a CERCLA response must constitute placement of a restricted RCRA hazardous waste for the LDRs to be applicable, site managers must evaluate whether the contaminants at the CERCLA site are RCRA bazardous wastes. Highlight 3 briefly describes the two types of RCRA hazardous wastes -listed and characteristic wastes.

\section{Highlight 3: RCRA HAZARDOUS WASTES}

A RCRA solid waste is hazardous if it is listed or exhibits a hazardous characteristic.

\section{Listed RCRA Hazardous Wastes}

Any waste listed in Subpart D of 40 CFR 261, including:

- F waste codes (Part 261.31)

- $\quad \mathrm{K}$ waste codes (Part 261.32)

- P waste codes (Part 261.33(e))

- U waste codes (Part 261.33(f))

Characteristic RCRA Hazardous Wastes

Any waste exhibiting one of the following characteristics, as defined in 40 CFR 261:

- Ignitability

- Corrosivity

- Reactivity

- Extraction Procedure (EP) Toxicity

\footnotetext{
- A solid waste is any material that is discarded or disposed of (i.e., abandoned, recycled in certain ways, or considered inherently waste-like). The waste may be solid, semi-solid, liquid, or a contained gaseous material. Exclusions from the definition (c.g, domestic sewage sludge) appear in 40 CFR 261.4(a). Exemptions (e.g., household wastes) are found in 40 CFR 261.4(b).
}

Site managers are not required to presume that a CERCLA hazardous substance is a RCRA bazardous waste unless there is affirmative evidence to support such a finding. Site managers, therefore, should use "reasonable efforts" to determine whether a substance is a RCRA listed or characteristic waste. (Current data collection efforts during CERCLA removal and 
remedial site investigations should be sufficient for this purpose.) For listed hazardous wastes, if manifests or labels are not available, this evaluation likely will require fairly specific information about the waste (e.g., source, prior use, process type) that is "reasonably ascertainable" within the scope of a Superfund investigation. Such information may be obtained from facility business records or from an examination of the processes used at the facility. For characteristic wastes, site managers may rely on the results of the tests described in 40 CFR 261.21 - 261.24 for each characteristic or on knowledge of the properties of the substance. Site managers should work with Regional RCRA staff, Regional Counsel, State RCRA staff, and Superfund enforcement personnel. as appropriate, in making these determinations.

In addition to understanding the two categories of RCRA hazardous wastes, site managers will also need to understand the derived-from rule, the mixture rule, - and the contained-in interpretation to identify correctly whether a CERCLA substance is a RCRA hazardous waste. These three principles, as well as an introduction to the RCRA delisting process, are described below.

\section{Derived-from Rule (40 CFR 261.3(c)(2))}

The derived-from rule states that any soiid waste derived from the treatment, storage, or disposal of a listed RCRA hazardous waste is itself a listed hazardous waste (regardless of the concentration of hazardous constituents). For example, ash and scrubber water from the incineration of a listed waste are hazardous wastes on the basis of the derived-from rule. Solid wastes derived from a characteristic hazardous waste are hazardous wastes only if they exhibit a characteristic.

\section{Mixture Rule (40 CFR 261.3(a)(2))}

Under the mixture rule, when any solid waste and a listed hazardous waste are mixed, the entire mixture is a listed hazardous waste. For example, if a generator mixes a drum of listed F006 electroplating waste with a non-hazardous wastewater (wastewaters are solid wastes - see Highlight 3), the entire mixture of the F006 and wastewater is a listed hazardous waste.
Mixtures of solid.wastes and characteristic hazardous wastes are hazardous only if the mixture exhibits a characteristic.

\section{Contained-in Interpretation (OSW Memorandum dated} November 13, 1986)

The contained-in interpretation states that any mixture of a non-solid waste and a RCRA listed hazardous waste must be managed as a hazardous waste as long as the material contains (i.e., is above health-based levels) the listed hazardous waste. For example, if soil or ground water (i.e., both non-solid wastes) contain an F001 spent solvent. that soil or ground water must be managed as a RCR th hazardous waste, as long as it "contains" the FOOI spent soisent.

Delisting (40 CFR 260.20 and 22)

To be exempted from the RCRA hazar wus waste "system," a listed hazardous waste, a mixtur: of a listed and solid waste, or a derived-from waste must be delisted (according to 40 CFR 260.20 and .22). Characteristic hazardous wastes never need to be delisted, but can be treated to no longer exhibit the characteristic. A contained-in waste also does not have to be delisted; it only has to "no longer contain" the hazardous waste.

If site managers determine that the hazardous substance(s) at the site is a RCRA hazardous waste(s), they should also determine whether that RCRA waste is a California list waste. California list wastes are a distinct category of RCRA wastes restricted under the LDRs (see Superfund LDR Guide \#2).

\section{IS THE RCRA WASTE RESTRICTED UNDER THE LDRs?}

If a site manager determines that a CERCLA waste is a RCRA hazardous waste, this waste also must be restricted for the LDRs to be an applicable requirement. A RCRA hazardous waste becomes a restricted waste on its HSWA statutory deadline or sooner if the Agency promulgates a standard before the deadline. Because the LDRs are being phased in over a period of time (see Highlight 4), site managers may need to determine what type of restriction is in 
remedial site investigations should be sufficient for this purpose.) For listed bazardous wastes, if manifests or labels are not available, this evaluation likely will require fairly specific information about the waste (e.g., source, prior use, process type) that is "reasonably ascertainable" within the scope of a Superfund investigation. Such information may be obtained from facility business records or from an examination of the processes used at the facility. For characteristic wastes, site managers may rely on the results of the tests described in 40 CFR 261.21 - 261.24 for each characteristic or on knowledge of the properties of the substance. Site managers should work with Regional RCRA staff, Regional Counsel. State RCRA staff, and Superfund enforcement personnel, as appropriate, in making these determinations.

In addition to understanding the two categories of RCRA hazardous wastes, stte managers will also need to understand the derived-from rule, the mixture rule, and the contained-in interpretation to identify correctly whether a CERCLA substance is a RCRA hazardous waste. These three principles, as well as an introduction to the RCRA delisting process, are described below.

\section{Derived-from Rule (40 CFR 261.3(c)(2))}

The a.redi-from rule states that any solid waste deriv in irom the treatment. storage, or disposal of a listed RCRA bazardous waste is itself a listed hazardous waste (regardless of the concentration of hazardius constituents). For example, ash and scrubber water from the incineration of a listed waste are hazardous wastes on the basis of the derived-from rule. Solid wastes derived from a characteristic bazardous waste are hazardous wastes only if they exhibit a characteristic.

\section{Mixture Rule (40 CFR 261.3(a)(2))}

Under the mixture rule, when any solid waste and a listed hazardous waste are mixed, the entire mixture is a listed hazardous waste. For example, if a generator mixes a drum of listed F006 electroplating waste with a non-hazardous wastewater (wastewaters are solid wastes - see Highlight 3 ), the entire mixture of the F006 and wastewater is a listed hazardous waste.
Mixtures of solid wastes and characteristic hazardous wastes are hazardous only if the mixture exhibits a characteristic.

\section{Contained-in Interpretation (OSW Memorandum dated November 13, 1986)}

The contained-in interpretation states that any mixture of a non-solid waste and a RCRA listed hazardous waste must be managed as a hazardous waste as long as the material contains (i.e., is above health-based levels) the listed hazardous waste. For example, if soil or ground water (i.e., both non-solid wastes) contain an F001 spent solvent, that soil or ground water must be managed as a RCRA hazardous waste, as long as it "contains" the F001 spent solvent.

\section{Delisting (40 CFR 260.20 and 22)}

To be exempted from the RCRA hazardous waste "system," a listed hazardous waste, a mixture of a listed and solid waste. or a derived-from waste must be delisted (according to 40 CFR 260.20 and .22). Characteristic hazardous wastes never need to be delisted, but can be treated to no longer exhibit the characteristic. A contained-in waste also does not have to be delisted: it only has to "no longer contain" the hazardous waste.

If site managers determine that the hazardous substance(s) at the site is a RCRA hazardous waste(s), they should also determine whether that RCRA waste is a California hist waste. California list wastes are a distinct category of RCRA wastes restricted under the LDRs (see Superfund LDR Guide \#2).

\section{(3) IS THE RCRA WASTE RESTRICTED UNDER THE LDRs?}

If a site manager determines that a CERCLA waste is a RCRA hazardous waste, this waste also must be restricted for the LDRs to be an applicable requirement. A RCRA hazardous waste becomes a restricted waste on its HSWA statutory deadline or sooner if the Agency promulgates a standard before the deadline. Because the LDRs are being phased in over a period of time (see Highlight 4), site managers may need to determine what type of restriction is in 


\section{Highlight 4: LDR STATUTORY DEADLINES}

\begin{tabular}{|c|c|}
\hline Waste & Statutory Deadline \\
\hline $\begin{array}{l}\text { Spent Solvent and Dioxin- } \\
\text { Containing Wastes }\end{array}$ & November 8,1986 \\
\hline California List Wastes & July 8,1987 \\
\hline First Third Wastes & August 8, 1988 \\
\hline $\begin{array}{l}\text { Spent Solvent. Dioxin- } \\
\text { Containing, and California } \\
\text { List Soil and Debris From } \\
\text { CERCLA/RCRA Corrective } \\
\text { Actions }\end{array}$ & Vovember \&. 1988 \\
\hline Second Third Wastes & June 8. 1989 \\
\hline Third Third Wastes & May 8, 1990 \\
\hline $\begin{array}{l}\text { Vewly Identified } \\
\text { Wastes }\end{array}$ & $\begin{array}{l}\text { Within } 6 \text { months of } \\
\text { identification as a } \\
\text { hazardous waste }\end{array}$ \\
\hline
\end{tabular}

effect at the time placement is to occur. For example, if the RCRA hazardous wastes at a site are currently under a national capacity extension when the CERCLA decision document is signed, site managers should evaluate whether the response action will be completed before the extension expires. If these wastes are disposed of in surface impoundments or landfills prior to the expiration of the extension, the receiving unit would have to meet minimum technology requirements, but the wastes would not have to be treated to meet the LDR treatment standards.

\section{APPLICABILITY DETERMINATIONS}

If the site manager determines that the LDRs are applicable to the CERCLA response based on the previous three questions, the site manager must: (1) comply with the LDR restriction in effect, (2) comply with the LDRs by choosing one of the LDR compliance options (e.g., Treatability Variance, No Migration Petition), or (3) invoke an ARAR waiver (available only for on-site actions). If the LDRs are determined not to be applicable, then, for on-site actions only, the site manager should determine if the LDRs are relevant and appropriate. The process for determining whether the LDRs are applicable to a CERCLA action is summarized in Highlight 5.

\section{Highlight 5 - DETERMINING WHEN LDRS ARE APPLICABLE REQUIREMENTS}

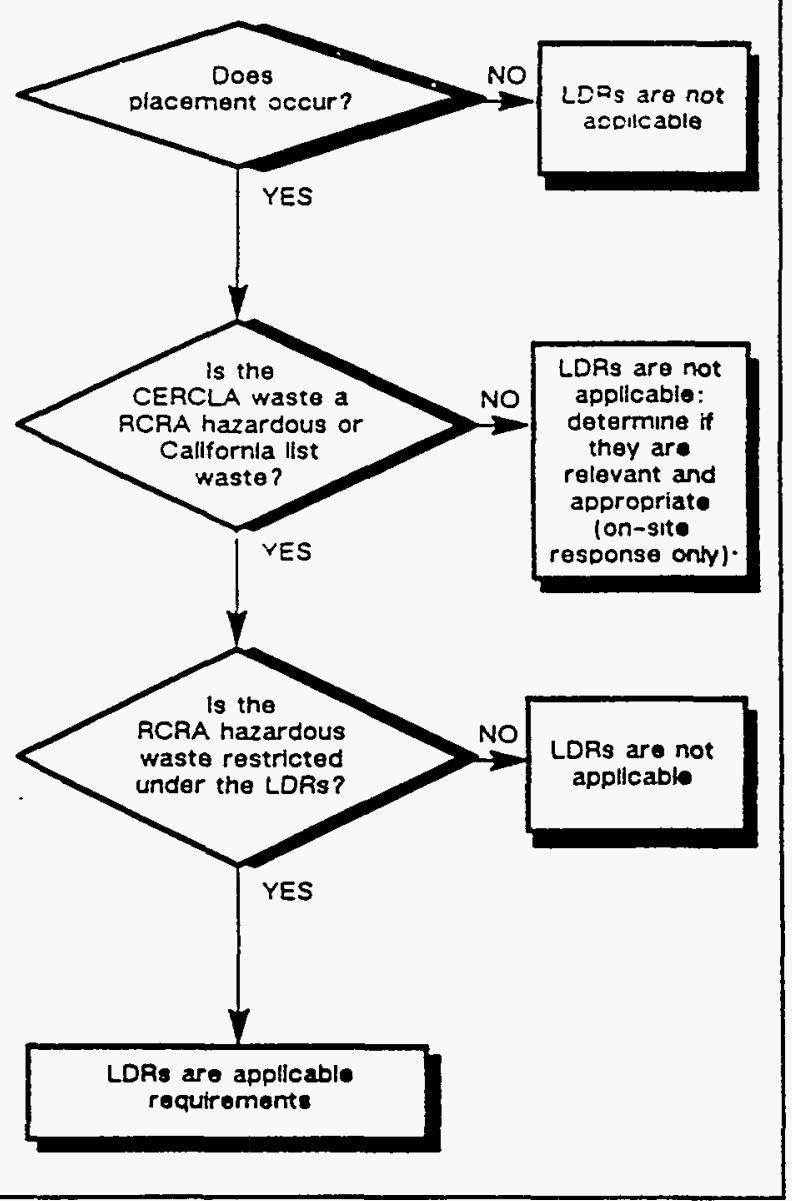




\section{SECTION F}

Superfund IDR Guide \#6A,

Obtaining a Soil and Debris Treatability

Variance for Remedial Actions 


\section{Obtaining a Soil and Debris Treatability Variance for Remedial Actions}

CERCLA response actions must comply with the RCRA Land Disposal Restrictions (LDRs) when they are determined to be applicable or relevant and appropriate requirements (ARARs). (The Agency has decided, however, that the LDRs are not relevant and appropriate for soil and debris wastes at this time.) For the LDRs to be applicable, the CERCLA response action must constitute placement of a restricted RCRA hazardous waste (see LDR Guide \#5). Compliance with the LDRs will involve either meeting the LDR treatment standards, other LDR restrictions (e.g., soft hammers), or satisfying the requirements of one of the other alternate LDR compliance options (e.g., Treatability Variance, Equivalent Treatment Method Petition). This guide outlines the process for obtaining and complying with a Treatability Variance for soil and debris that are contaminated with RCRA hazardous wastes for which the Agency has set treatment standards. More detailed guidance on Superfund compliance with the LDRs is being prepared by the Office of Solid Waste and Emergency Response (OSWER).

\section{BASIS FOR A TREATABILITY VARIANCE}

When promulgating the LDR treatment standards, the Agency recognized that treatment of wastes to the LDR vatment standards would not always be possible or .propriate. In addition, the Agency recognized the importance of ensuring that the LDRs do not unnecessarily restrict the development and use of alternative and innovative treatment technologies for remediating hazardous waste sites. Therefore, a Treatability Variance process ( 40 CFR \$268.44) is available to comply with the LDRs when a Superfund waste differs significantly from the waste used to set the LDR treatment standard such that:

- The LDR standard cannot be met; or

- The best demonstrated available technology (BDAT) used to set the standard is inappropriate for the waste.

Superfund site managers (OSCs, RPMs) may need to seek a Treatability Variance to comply with the LDRs when managing restricted soil and debris wastes (see Highlight 1) because the LDR treatment standards are based on treating less complex matrices of industrial process wastes (except for the dioxin standards, which are based on treating contaminated soil). A Treatability Variance does not remove the requirement to treat restricted soil and debris wastes. Rather, under a Treatability Variance, alternate treatment levels are established based on data from actual treatment of soil, or best management practices for debris.

Although the specific justification required to obtain a Treatability Variance may differ from site-to-site, site unagers generally will make this justification on the basis

(1) Available information on the performance capabilities of the technology(ies) being considered; (2) Site-specific conditions that may affect the implementation or effectiveness of those technologies; and (3) The remediation goals of the CERCLA response action.
At many sites, data from treatability studies conducted during the RI/FS will suffice as justification for obtaining a Treatability Variance. For example, if data from treatability studies indicate that the full-scale operation of a specific treatment technology cannot consistently meet the LDR treatment standards for all soil and debris (including the most contaminated waste areas of the site), site managers may use those data as justification to obtain a Treatability Variance for those contaminated soils and debris that cannot be treated to the standard.

When site-specific treatability study data are not available, surrogate data from the application of technologies to wastes of similar types may be used to assess the effectiveness of treating soil and debris and help site managers determine whether a Treatability Variance is warranted. Potential surrogate data sources include: (1) Treatability data bases, such as the one developed by EPA's Risk Reduction Engineering Laboratory; (2) Results from

\section{Highlight 1: SOIL AND DEBRIS}

Soil. Soil is defined as materials that are primarily of geologic origin such as sand, silt, loam, or clay, that are indigenous to the natural geologic environment at or near the CERCLA site. (In many cases, soil is mixed with liquids, sludges, and/or debris.)

Debris. Debris is defined as materials that are primarily non-geologic in origin, such as grass, trees, stumps, and man-made materials such as concrete, clothing, partially buried whole or empty drums, capacitors, and other synthetic manufactured materials, such as liners. (It does not include synthetic organic chemicals, but may include materials contaminated with these chemicals). 
treatability studies and from remedial actions conducted at other sites; and (3) Existing literature that describes the effectiveness/limitations of specific treatment technologies. Unless the surrogate data show that a technology operated at full scale can consistently meet the LDR treatment standards for all soil and debris that it will be called upon to treat, site managers should seek a Treatability Variance.

In some cases (especially when treatability studies are not conducted as part of the RI/FS), data that indicate whether a treatment technology or process can attain the LDR treatment standards may not be available. This situation may arise when an innovative technology is being considered, or when a "demonstrated" technology is being applied to wastes for which performance data do not exist. Under such circumstances, site managers may select a particular technology as the preferred alternative, if there are technically sound reasons to believe that it will perform effectively. The specific selection criteria (e.g., long- and short-term effectiveness, implementability) upon which the rationale would be based should be included when profiling the alternative in the Detailed Analysis chapter of the FS report. When there are no actual performance data available that indicate the LDR treatment standards can be met consistently for all soil and debris, site managers should seek a Treatability Variance. Site specific conditions need to be considered and documented at sites where a Treatability Variance is sought.

\section{HOW TO OBTAIN A TREATABLITY VARIANCE FOR SOIL AND DEBRIS WASTES}

Once it is determined that a CERCLA waste is a sol or debris, and that a Treatability Variance will be necessary (i.e., the LDRs are applicable for the response action addressing soil or debris wastes and there is a reasonable doubt that the standards can be met consistently for all the soil and debris wastes requiring treatment), site managers should initiate the process of obtaining a Variance. For remedial actions, the need for a Treatability Variance should be evident during the RI/FS as information on waste types is collected, potential waste management strategies are evaluated, and the determination of whether the LDRs are applicable is made.

\section{Obtaining a Treatability Variance}

Obtaining a Treatability Variance for remedial actions will involve: (1) documenting the rationale and justification for the Treatability Variance in the FS Report; (2) announcing the intent to seek a Treatabiiity Variance in the Proposed Plan; and (3) granting of the Treatability Variance by the Regional Administrator or the Assistant Administrator/OSWER when the ROD is signed.

Bighlight 2 - IFFORMATION TO BE INCLUDED IN THE DOCTRENTATTON OF A SOII AFD DEBRIS

IREATABILITY VARIANCE IN AN RI/FS REPORT FOR ON-SITE AKD OFF-SITE CERCIA RESPONSE ACTIONS

\section{OR-SIIE}

Description of the Proposed Action (e.8., "Applying for an LDR Treatability Variance under 40 CFR \$268.44);

- A statement of need and justification for the proposed action (e.B., "data do not indicate that full scale treatment can consistently attain the LDR treatment standards for all waste areas, including the most contaminated areas, at the site.")

A description of the soil or debris waste $(e .8$. information on the physical and chemical characteristics of the waste, including waste analysis data) and description of the source of the contamination;

If the soil and debris waste has been treated (e.8., treatability study), or surrogate data are available, a description of the treatment system (e.8., process design, operating conditions) and explanation of why the LDR treatment standard cannot be achieved using the treatment system or why the BDAT technology is inappropriate for the waste;

- If the soil and debris waste has not been treated, an explanation of why the BDAT treatment technology is inappropriate or why treatment of the waste will not be able to achieve the LDR treatment standards;

- A description of the methodologies and equipment used to obtain representative samples, a description of the sanple handling and preparation techniques, and a description of the QA/QC measures for waste analysis and treatment.

A description of any alternative treatment methods examined by the petitioner a description of the treatment method that the petitioner believes is appropriate to treat waste and an identification of the interim "treatment levels" developed by the lead agency for the waste constituents or best management practices; and

- For each alternative for which a Treatability Variance is required, the specific treatment level range to be achieved to comply with the LDRs through a Ireatability Variance (see Eighlight 5 to determine these treatment levels).

\section{OFF-SIIE}

For off-site Treatability Variances, the documentation requirements above should be extracted from the RI/FS report and combined with the following information in a separate document:

- Petitioner's name and address and identification of an authorized contact person (if different);

- Statement of petitioner's interest in obtaining a Treatability Variance; and

This document

prior to the first shipment of wastes (or treatment residuals) to the receiving treatment or disposal facility. 


\section{FS Report}

The FS Report should contain the necessary information see Highlight 2) to justify a Treatability Variance using, where appropriate, data and findings from the RI Report. In the Detailed Analysis of Alternatives chapter of the FS Report, a general discussion of why a Treatability Variance is necessary should be included in the description of each alternative for which a variance is required. This description also should specify the treatment level range(s) that the treatment technology would attain for each waste constituent restricted under the LDRs and the primary contaminants of concern identified during the Superfund baseline risk assessment. (The more specific and detailed information, such as relevant waste analysis data from sampling, should be placed in an appendix to the report.) In addition, under the Comparative Analysis of Alternatives section, when discussing the "Compliance with ARARs Criteria," site managers should indicate which alternatives will require a Treatability Variance to comply with the LDRs.

\section{Highlight 3 - SAMPLE LANGUAGE FOR THE PROPOSED PLAN}

\section{Description of Alternatives section}

This altemative will comply with the LDRs through a Treatability Variance under 40 CFR 268.44. This Variance will result in the use of [specify technologv] to attain the Agency's interim "treatment levels/ranges" for the contaminated soil at the site (see Detailed Analysis of Altematives Chapter of the FS Report for the specific treatment levels for each constituent).

Evaluation of Alternatives section, under "Compliance with ARARs"

The LDRs are ARARs for [Enter number] of [Enter total number of altematives] remedial alternatives being considered. [Enter number] of the [Enter total number of altematives] altematives would comply with the LDRs through a Treatability Variance.

\section{Community's Role in the Selection Process section}

This Proposed Plan also seeks comment on the use of a Treatability Variance to comply with LDRs for each of the altematives for which one is required.

\section{Proposed Plan}

The intent to seek a Treatability Variance for a Frticular alternative should be clearly stated in the escription of Alternatives section of the Proposed Plan.
Because the Proposed Plan solicits public comment on all of the alternatives and not just the preferred option, the intent to obtain a Treatability Variance should be identified for every alternative for which a Variance is required. This opportunity for public comment on the Proposed Plan fulfills the requirements for public notice and comment (off-site actions only) on the Treatability Variance as required in RCRA \$268.44. Sample language for the Proposed Plan is provided in Highlight 3.

\section{$\underline{\text { Record of Decision }}$}

A Treatability Variance is granted and becomes effective when the Record of Decision (ROD) is signed by the Regional Administrator or Assistant Administrator/ OSWER. The documentation provided in the ROD for a Treatability Variance should be a concise synopsis of the information provided in the FS Report. In the Description of Alternatives section, as part of the discussion of major applicable requirements associated with each remedial option, site managers should include a statement (as was done in the FS report) that explains why a Treatability Variance is justified and should list the treatment level range(s) that the selected technology will attain for each constituent. Sample language for the ROD is provided in Highlight 4.

\section{Highlight 4: SAMPLE LANGUAGE FOR A RECORD OF DECISION}

Description of Alternatives section:

Because existing and available data do not demonstrate that the full-scale operation of this treatment technology can attain the LDR treatment standards consistently for all soil and debris wastes to be addressed by this action, this alternative will comply with the LDRs through a Treatability Variance for the wastes that cannot be treated to meet the standard. The treatment level range established through a Treatability Variance that [Enter technology] will attain for each constituent as determined by the indicated analyses are:
Barium
Mercury
Vanadium
TCE
Cresols
$0.1-40 \mathrm{ppm}(T C L P)$
$0.0002-0.008 \mathrm{ppm}(T C L P)$
$0.2-22 \mathrm{ppm}(T C L P)$
95-99.9\% reduction (TWA)
90-99.9\% reduction (TWA)

In the Comparative Analysis section, under "Compliance with ARARs," site managers should indicate which of the alternatives will comply with the LDRs through a Treatability Variance. Under the Statutory Determination section (Compliance with ARARs), site managers should identify the LDRs as an ARAR and indicate that a Treatability Variance is being used to comply. 
HOW TO COMPLY WITH A TREATABILITY VARIANCE, FOR SOIL AND DEBRIS WASTES

\section{Soil Wastes}

Once site managers have identified the RCRA waste codes present at the site, the next step is to identify the BDAT constituents of those RCRA waste codes found at the site, and to divide these constituents into one of the structural/functional groups shown in column 1 of Highlight 5. After dividing the BDAT constituents into their respective structural/functional groups, the next step is to compare the concentration of each constituent with the threshold concentration (see column 3 of Highlight 5) and to select the appropriate concentration level or percent reduction range. If the concentration of the restricted constituent is less than the threshold concentration, the waste should be treated to within the concentration range. If the waste concentration is above the threshold, the waste should be treated to reduce the concentration of the waste to withis the specified percent reduction range. Once the appropriate treatment range is selected, the third step is to identify and select a specific technology that can achieve the necessary concentration or percent reduction. Column 5 of Highlight 5 lists technologies that (based on existing performance data) can attain the alternative Treatability Variance levels.

During the implementation of the selected treatment technology, periodic analysis using the appropriate testing procedure (i.e., total waste analysis for organics and TCLP for inorganics) will be required to ensure the alternate treatment levels for the BDAT constituents requiring control are being attained and thus can be land disposed without further treatment.

Highlight 5. ALTERNATE TREATABILTYY VARIANCE LEVELS AND TECHNOLOGIES FOR STRUCTURAL/FUNCTIONAL GROUPS

\begin{tabular}{|c|c|c|c|c|}
\hline $\begin{array}{l}\text { Structural } \\
\text { Functional } \\
\text { Groups }\end{array}$ & $\begin{array}{l}\text { Concentration } \\
\text { Range } \\
\text { (ppm) }\end{array}$ & $\begin{array}{l}\text { Threshold } \\
\text { Concentration } \\
\text { (ppm) }\end{array}$ & $\begin{array}{l}\text { Percent } \\
\text { Reduction } \\
\text { Range }\end{array}$ & $\begin{array}{l}\text { Technologles that actileved } \\
\text { recommended oftuluent } \\
\text { concentration guldance** }\end{array}$ \\
\hline 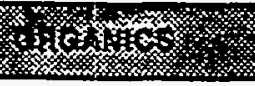 & His & 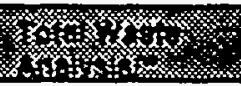 & +4 & \\
\hline $\begin{array}{l}\text { Halogenatod } \\
\text { Non-Polar } \\
\text { Aromatics } \\
\end{array}$ & $0.5-10$ & 100 & $90-99.9$ & $\begin{array}{l}\text { Blological Traatment, Low Tomp. Stripping. } \\
\text { Soll Westing. Thermal Destruction }\end{array}$ \\
\hline Dioxins & $0.00001-0.05$ & 0.5 & $90-99.9$ & Dechlorination. Soll Washing, Thermal Destuction \\
\hline PCBs & $0.1-10$ & 100 & $90-99.9$ & $\begin{array}{l}\text { Biobogical Trastment, Decthorination. Soll Weathing. } \\
\text { Thermal Destruction }\end{array}$ \\
\hline Herbicides & $0.002-0.02$ & 0.2 & $90-99.9$ & Thermal Dectruction \\
\hline $\begin{array}{l}\text { Halogenatod } \\
\text { Phonols }\end{array}$ & $0.5-40$ & 400 & $\infty 0-\infty$ & 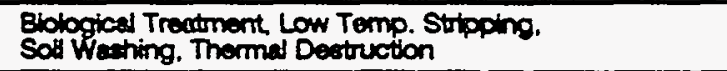 \\
\hline $\begin{array}{l}\text { Halogenatad } \\
\text { Aliphatics }\end{array}$ & $0.5-2$ & 40 & $85-89.8$ & $\begin{array}{l}\text { Blological Treatiment, Low Temp. Stripping. Soll Westing. } \\
\text { Thermal Destruetion }\end{array}$ \\
\hline $\begin{array}{l}\text { Halogenated } \\
\text { Cyclics }\end{array}$ & $0.5-20$ & 200 & $90-99.9$ & Thermal Destruction \\
\hline $\begin{array}{l}\text { Nitratod } \\
\text { Aromatcs }\end{array}$ & $2.5-10.0$ & 10.000 & $99-99.98$ & $\begin{array}{l}\text { Blological Trantment, Soll Washing } \\
\text { Thermal Destruction }\end{array}$ \\
\hline Heterocyclics & $0.5-20$ & 200 & $90-99.9$ & $\begin{array}{l}\text { Biological Treaturent, Low Temp. Stripping. Soll Washing. } \\
\text { Thermel Destruction }\end{array}$ \\
\hline $\begin{array}{l}\text { Polynuclear } \\
\text { Aromatics }\end{array}$ & $0.5-20$ & 400 & $95-99.9$ & $\begin{array}{l}\text { Biological Treatment, Low Temp. Stripping. Soll Westhing. } \\
\text { Thermel Destruction }\end{array}$ \\
\hline $\begin{array}{l}\text { Other Polar } \\
\text { Organics }\end{array}$ & $0.5-10$ & 100 & $90-\$ 9.8$ & 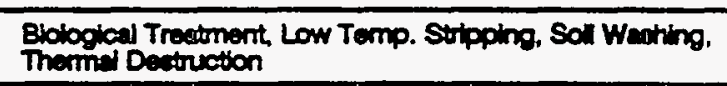 \\
\hline 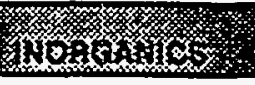 & $\Leftrightarrow$ & 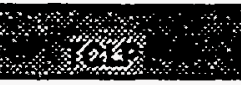 & & 1 \\
\hline Antimony & $0.1-0.2$ & 2 & $90-99$ & Immobitization \\
\hline Arsenic & $0.27-1$ & 10 & $90-99.9$ & Immobitization. Soll Washing \\
\hline Barium & $0.1-40$ & 400 & $90-99$ & Irrmotication \\
\hline Chromium & $0.5-6$ & 120 & $95-99.9$ & Immobilzation. Soil Washing \\
\hline Nicket & $0.5-1$ & 20 & $95-99.9$ & Immob'lleation, Soll Washing \\
\hline Selenium & 0.005 & 0.08 & $90-99$ & Immobitization \\
\hline Venadium & $0.2-22$ & 200 & $90-99$ & Immotittzation \\
\hline Cadmium & $0.2-2$ & 40 & $95-99.9$ & Immobitization. Soll Weshing \\
\hline Lead & $01-3$ & 300 & $99-99.9$ & Immobillzation, Soll Westhing \\
\hline Mercury & $0.0002-0.008$ & 0.06 & $90-99$ & immoblication \\
\hline
\end{tabular}

- TCLP also may be used when evaluating wase with relatively low levels of arganics that have been reated though an imanobitimation process.

- Other lecthrologies may be used if treatability sudies or other infomation indicates that they can actieve the mecescary concentruion or percent-reduction mange 
Because of the variable and uncertain characteristics associated with unercavated wastes, from which only sampling data are available, treatment systems generally

zuld be designed to achieve the more stringent end of the

atment range (e.g, 0.5 for chromium, see column 2 of raighlight 5) to ensure that the treatment residuals from the most contaminated portions of the waste fall below the "no exceedance" levels (c.g., $6.0 \mathrm{ppm}$ for chromium). Should data indicate that the treatment levels set through the Treatability Variance are not being attained (i.e., treatment residuals are greater than the "no exceedance" level), site managers should consult with Headquarters.

Under some circumstances, the need to obtain a Treatability Variance may not be evident until after a ROD is signed. This situation may arise when: (1) initial assumptions made during the RI/FS that the LDR treatment standards would be met are proven to be incorrect during the remedial design/action (RD/RA) phase; or (2) previously undiscovered evidence is obtained during $R D / R A$ that the CERCLA waste contains a RCRA restricted waste and the LDRs are then determined to be applicable but cannot be met. In such situations, a site manager would need to prepare an explanation of significant differences (ESD) from the ROD and make it available to the public to explain the need for a Treatability Variance. In addition, unlike other ESDs that do not require public comment under CERCLA section 117(c), if the ESD involves granting a Treatability Variance, an opportunity for public comment would be required to fulfill the public -ntice and comment requirements for a Treatability iance under 40 CFR $\$ 268.44$.

\section{Debris Wastes}

Site managers should use the same process for obtaining a Treatability Variance described above for types of debris that are able to be treated to the alternate treatment levels (c.g., paper, plastic). However, for most types of debris (e.g., concrete, steel pipes), which generally cannot be treated, site managers should use best management practices. Depending on the specific characteristies of the debris, these practices may include decontamination (c.8. triple rinsing) or destruction.

\section{LDRS IN SUPERFUND ACTIONS}

Because of the important role the LDRs may play in Superfund cleanups, site managers need to incorporate early in the $R I / F S$ the neccesary investigative and analytical procedures to determine if the LDRs are applicable for remedial alternatives that involve the "placement" of wastes. When the LDRs are applicable, site managers should determine if the treatment processes associated with the alternatives can attain either the LDR treatment standards or the alternate levels that would be established under a Treatability Variance.

Site managers must first evaluate whether restricted RCRA waste codes are present at the site, identify the BDAT constituents requiring control, and compare the BDAT constituents with the Superfund primary constiruents of concern from the baseline risk assessment. This process identifies all of the constituents for which remediation may be required. Once the viable alternatives are identified in the FS, site managers should evaluate those involving the treatment and placement of restricted RCRA hazardous wastes to ensure their respective technology process(es) will attain the appropriate treatment levels (i.e., either LDR treatment standard or Treatability Variance alternate treatment levels for restricted RCRA hazardous wastes) and, in accordance with Superfund goals, reductions of 90 percent or greater for Superfund primary contaminants of concern. The results of these evaluations are documented in the Proposed Plan and ROD. An illustration of the integration of LDRs and Superfund is shown in Highlight 6. An example of the process for complying with a Treatability Variance for contaminated soil and debris is presented in Highlight 7.

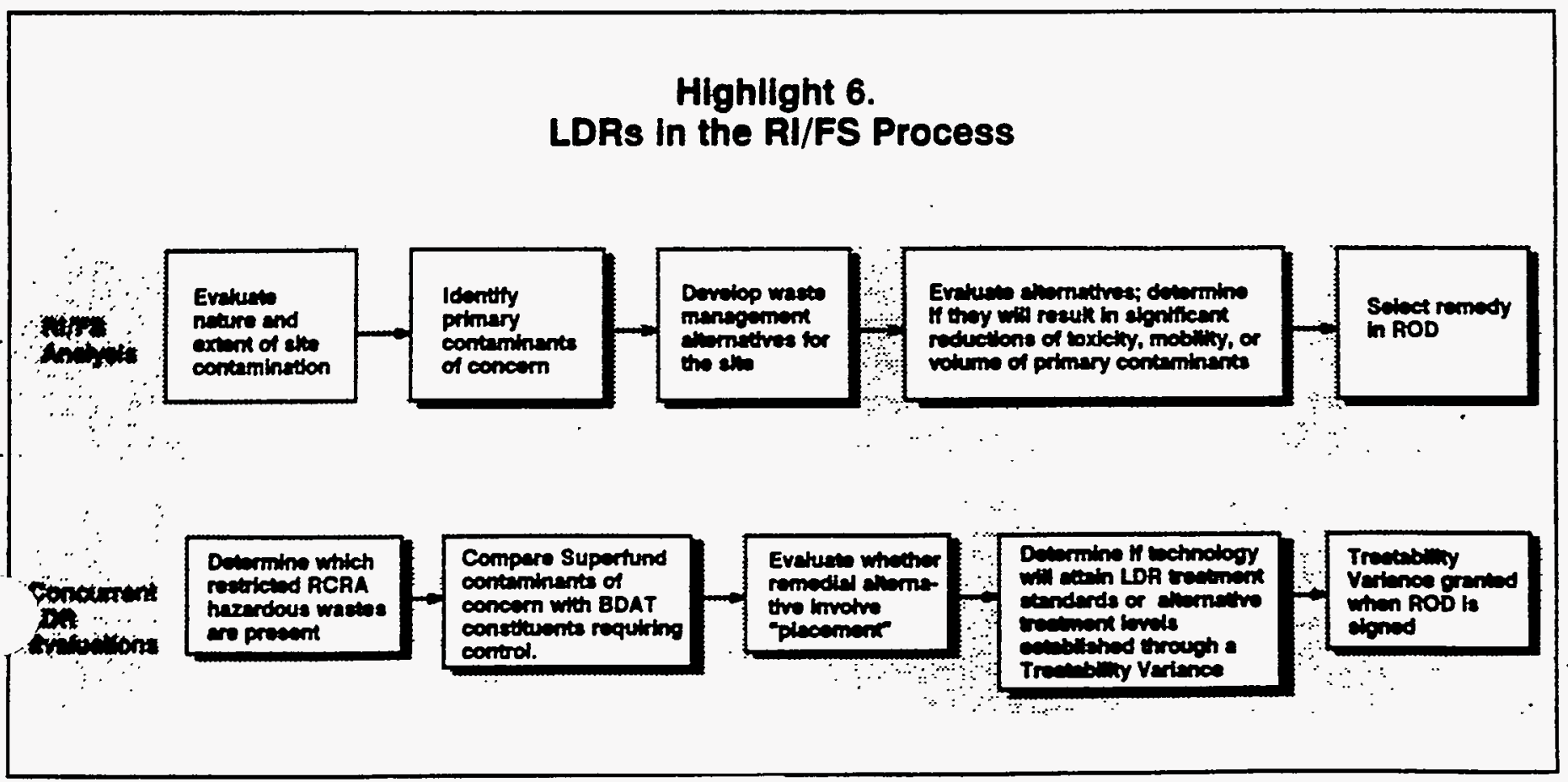




\section{Highlight 7: IDENTIFICATION OF TREATMENT LEVELS FOR A TREATABILITY VARIANCE}

As part of the RI, it has been determined that soils in one location at a site contain Foo6 wastes and cresols (phich site records indicate were an FOO4 waste). Arsenic also was found in soils at a separate location. The baseline risk assessment identified cadmium, chromium, lead, and assenic as primary contaminants of concem. The concentration range of all of the constituents found at the site included:

\begin{tabular}{|c|c|c|c|c|c|}
\hline Constituent & $\begin{array}{c}\text { Total Concentration } \\
(\mathrm{mg} / \mathrm{kg})\end{array}$ & $\begin{array}{l}\text { TCLP } \\
(\mathrm{mg} / \mathrm{l})\end{array}$ & Constituent & $\begin{array}{c}\text { Total Concentration } \\
\text { (mg/kg) }\end{array}$ & $\begin{array}{l}\text { TCIP } \\
(\mathrm{mg} / 1)\end{array}$ \\
\hline $\begin{array}{l}\text { Cadmium } \\
\text { Chromium } \\
\text { Cyanides } \\
\text { Lead }\end{array}$ & $\begin{array}{rr}2,270-16,200 \\
3,160-4,390 \\
80-\quad 150 \\
500-\quad 625\end{array}$ & $\begin{array}{c}120-146 \\
30-56 \\
1-16 \\
2-12.5\end{array}$ & $\begin{array}{l}\text { Nickel } \\
\text { Silver } \\
\text { Cresols } \\
\text { Arsenic }\end{array}$ & $\begin{array}{r}100-140 \\
1-3 \\
50-600 \\
800-1,900\end{array}$ & $\begin{array}{l}1-6.5 \\
- \\
25-4 \\
3-9\end{array}$ \\
\hline
\end{tabular}

Four remedial alternatives are being considered: (1) Low temperature thermal stripping of soil contaminated with cresols followed by stabilization of the ash; (2) Stabilization of the soil in a mobile unit; (3) In-situ stabilization; and (4) Capping of wastes. Each of these alternatives must be evaluated to determine if they will result in significant reduction of the toxicity, mobility, or volume of the waste; whether "placement" occurs; and, if "placement" occurs, whether the treatment will attain LDR treatment standards or alternative treatment levels established through a Treatability Variance for the BDAT constituents requiring control.

\section{STEP 1: DENIUFY THE RESTRICTED CONSITIUENTS}

- Because F006 and F004 wastes have been identified at the site, the Superfund site manager must meet the treatment standards or alternate treatment levels established through a Treatability Variance for the BDAT constituents. These constituents are: Cadmium, Chromium, Lead, Nickel, Silver, and Cyanide for FO06 and Cresols for F004.

AND DIVIDE THE CONSTTTUENIS INTO THEIR STRUCTURAL/FUNCTIONAL GROUPS (see Highight 4):

- All of the FOO6 constituents are in the Inorganics structural/functional group.

- Cresols are in the Other Polar Organic Compounds structural/functional group.

- In accordance with program goals. the preferred remedy also should result in the effective reduction (i.e., at least 90 percent) of all primary constituents of concern (1.e.. Cadmium, Chromium, Lead, and Arsenic).

STEP 2: COMPARE THE CONCENTRATION THRESHOLD FOUND IN HIGHLIGHT 5 TO THE CONCENTRATIONS FOUND AT THE SITE AND CHOOSE EITHER THE CONCENTRATION LEVEX RANGE OR PERCENT REDUCIION RANGE FOR EACH RESTRICTED CONSTTTUENT.

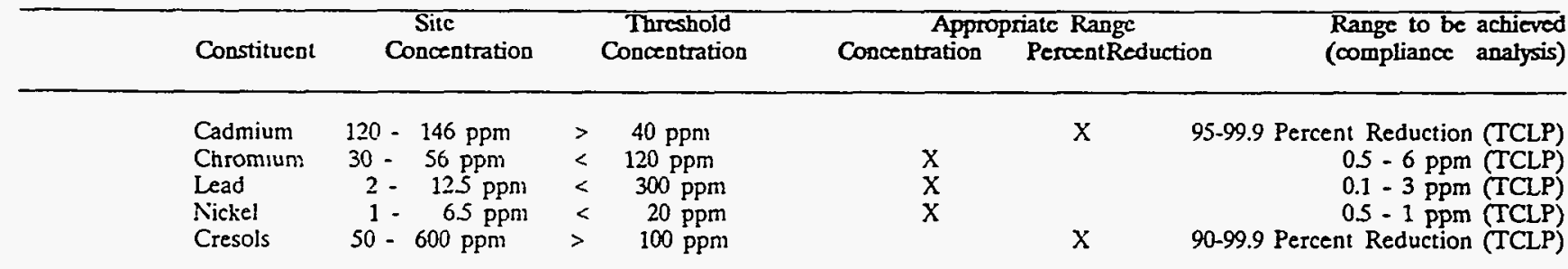

\section{STEP 3: DENIIFY TREATMENT TECHNOLOGIES THAT MEET THE TREATMENT RANGES.}

- Highlight 5 lists the technologies that achieved the alternate treatment levels for each siructural/functional group.

- Because cresols are present in relatively low concentrations (assumed for the purposes of this example), a TCLP may be used to determine if immobilization results in a sufficient reduction of mobility of this restricted RCRA hazardous waste. (Measures to address any volatization of organics during immobilization processes rill be necessary.)

- Immobilization also will result in the effective reduction in leachability (i.e., at least 90 percent) of arsenic, a Superfund primary contaminant of concern.

\begin{tabular}{|c|c|c|c|c|}
\hline Altemative & $\begin{array}{l}\text { Effective Reduction } \\
\text { of Toxicity, Mobility, Volume? }\end{array}$ & 'Placement?" & $\begin{array}{l}\text { Meet LDR Treatment } \\
\text { Standards for BDAT Constituents }\end{array}$ & $\begin{array}{l}\text { Meet Treatability Variance } \\
\text { Aiternate Levels? }\end{array}$ \\
\hline $\begin{array}{l}\text { 1. Lot temperature stripping/ } \\
\text { Stabilization } \\
\text { 2. Stabilization in mobile unit } \\
\text { 3. In-situ stabilization } \\
\text { 4. Capping in Place }\end{array}$ & $\begin{array}{l}\text { Yes } \\
\text { Yes } \\
\text { Yes (Mobility) } \\
\text { No }\end{array}$ & $\begin{array}{l}\text { Yes } \\
\text { Yes } \\
\text { No (LDR } \\
\text { No (LDR }\end{array}$ & $\begin{array}{ll}\text { No (not for cresols) } \\
\text { No (not for cresols) }\end{array}$ & $\begin{array}{l}\text { Yes } \\
\text { Yes } \\
-\end{array}$ \\
\hline
\end{tabular}

\footnotetext{
* Treatability studies conducted during RI/FS indicated the standard could not be met consistently for all soils contaminated with cresols.
}

a After balancing the tradeoffs among alternatives with respect to the nine evaluation criteria, the Agency determined that stabilization of wastes in a mobile unit is the preferred alternative. The next step is to seek and obtain a Treatability Variance for the preferred altemative in the Proposed Plan and ROD. 


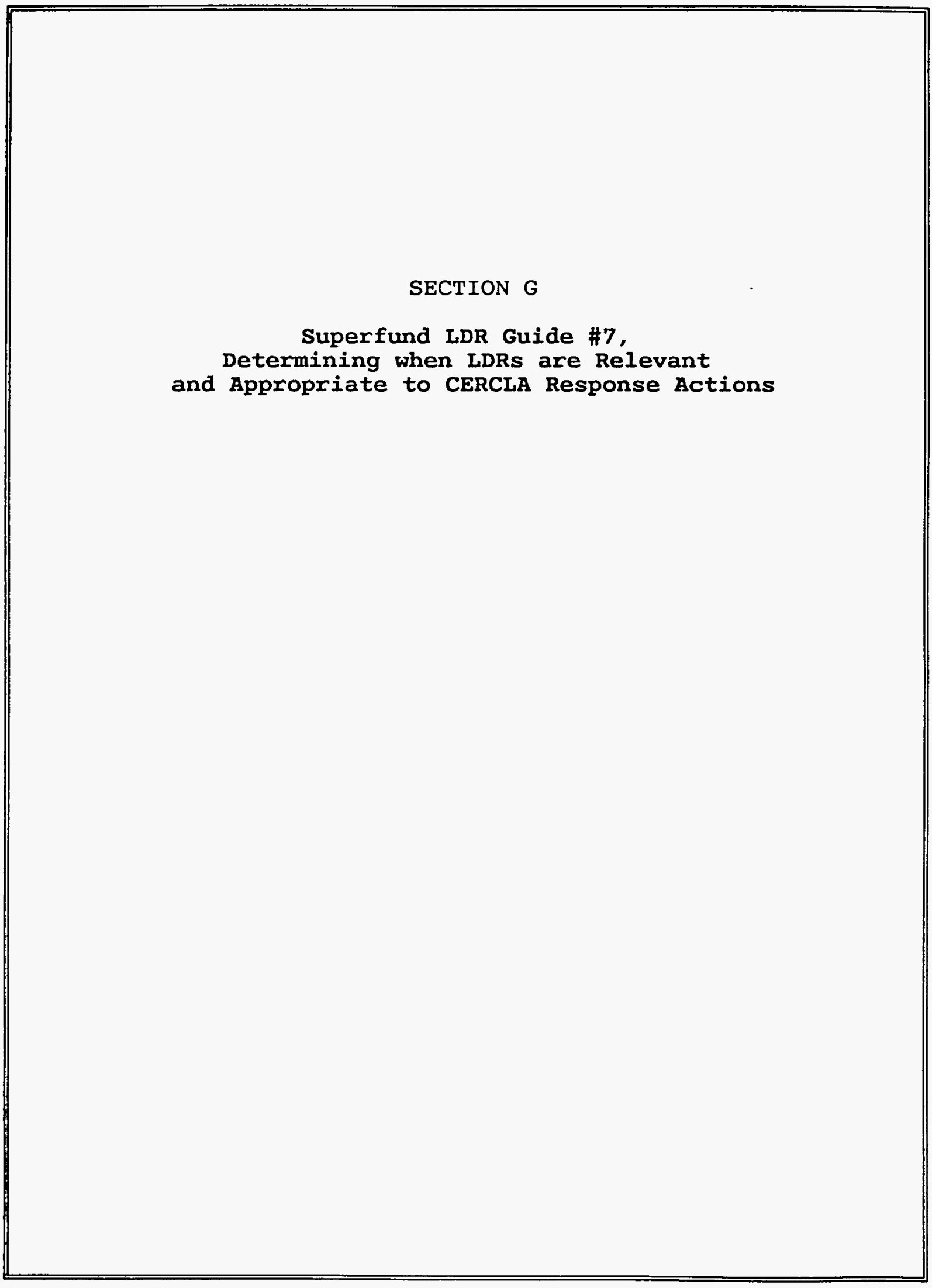




\section{United States \\ Environmental Protection Solid Waste and \\ Agency Emergency Response \\ Supertund Publication: \\ 9347.3-OBFS \\ December 1989 \\ Superfund LDR Guide \#7 \\ Determining When Land Disposal Restrictions (LDRs) Are Relevant and Appropriate to CERCLA Response Actions}

CERCLA Section 121(d)(2) specifies that on-site Superfund remedial actions shall attain "other Federal standards, requirements, criteria, limitations, or more stringent State requirements that are determined to be legally applicable or relevant and appropriate (ARAR) to the specified circumstances at the site." In addition, the National Contingency Plan (NCP) requires that on-site removal actions attain ARARs to the extent practicable. Off-site removal and remedial actions must comply with legally applicable requirements. This guide outlines the process ased to determine whether the Resource Conservation and Recovery Act (RCRA) land disposal restrictions (LDRs) established under the Hazardous and Solid Waste Amendments (HSWA) are "relevant and appropriate" to an on-site CERCLA response action. (See Superfund LDR Guide $\# 5$ for determining when LDRs are applicable to CERCLA response actions.) The guide also provides examples of when the LDRs are likely to be relevant and appropriate and when they are not. With respect to contaminated soil and debris. EPA is undertaking a rulemaking to establish specific LDRs; until this rulemaking is completed, EPA generally will not consider the LDRs to be relevant and appropriate for soil and debris contaminated with hazardous substances that are not RCRA restricted wastes. More detailed guidance on Superfund compliance with the LDRs is being prepared by the Office of Solid Waste and Emergency Response (OSWER).

\section{LDR RELEVANT AND APPROPRIATE DETERMINATIONS}

For on-site CERCLA responses that constitute placement, and for which the LDRs have been determined not to be applicable (i.e., the wastes being placed are not prohibited or restricted RCRA wastes), site managers should evaluate whether the LDRs are relevant and appropriate. As discussed in the CERCLA Compliance with Other Laws Manual (EPA, August 8, 1988), relevant and appropriate decisions require best professional judgment of site-specific factors to determine whether a requirement addresses problems or situations sufficiently similar to the circumstances of the release, or remedial action contemplated, and is well-suited to the site, and therefore, is both relevant and appropriate.

Section $300.400(\mathrm{~g})(2)$ of the proposed NCP [53 FR at 51436 (December 21, 1988)] outlines a number of factors pertaining to CERCLA situations and potential ARARs which should be compared to determine whether a requirement is both relevant and appropriate. The four pertinent factors to compare when evaluating the potential relevance and appropriateness of the LDRs are: (1) the action or activities regulated by the requirement (e.g., placement on the land) and the remedial action contemplated; (2) the purpose of the requirement and the purpose of the
CERCLA action; (3) the substances regulated by the requirement and the substances found at the CERCLA site; and (4) the medium regulated or affected by the requirement and the medium contaminated or affected at the CERCLA site. These factors are evaluated to determine whether the circumstances of the release and remedial action contemplated are such that use of the LDR requirements is well-suited to CERCLA response objectives.

The evaluation of the circumstances of a release is conducted as part of the remedial investigation, during which information is collected on contaminant sources, potential routes of migration, and potential human and environmental receptors of concern. The results of this effort (which is ultimately documented in the site characterization and baseline risk assessment chapters of the RI/FS report) are used to establish remedial action objectives for the areas or media contaminated at the site that pose a threat to human health and the environment. The site-specific CERCLA response objectives of the remedial action contemplated should be compared with the purpose or objectives of the LDRs as a first step in determining the potential relevance and appropriateness of the LDRs [proposed NCP factors (a) and (e)].

The objective of the LDRs is to achieve reductions in the toxicity and/or mobility of a 
hazardous waste, based on application of the best demonstrated available technology (BDAT), prior to its land disposal. While this objective will often be compatible with remedial alternatives designed to destroy highly concentrated, toxic, and mobile materials such as liquids, other remedial alternatives involving treatment of the principal threats of a site may have different objectives to which the LDRs are not wellsuited.

Once a decision is made that achieving BDAT reductions in the toxicity and/or mobility of a waste source is compatible with CERCLA response objectives for the site, site managers should utilize information on waste constituents and matrices collected as part of the site characterization to evaluate whether a CERCLA waste is "sufficiently similar" to a listed RCRA waste code or family of waste codes (e.g., K048-K052, petroleum refining wastes) such that the LDR standard for that waste code is appropriate for the CERCLA waste.

In determining whether a CERCLAt waste is sufficiently similar, site managers should consider whether the BDAT used to set the LDR standard would be effective for the CERCLAt waste. 'Technologies other than those used to set the BDAT itandards may be considered, although they must be :egarded as capable of meeting the promulgated zoncentration requirements.) Although a constituentjy-constituent analysis is not necessary for relevant ind appropriate determinations, a general comparison of the waste constituents and matrices is useful for dentifying waste codes to which a CERCLA waste may se similar, and therefore, helpful in the identification of technologies that may be appropriate for :onsideration.

If a CERCLA waste that consists of a complex nixture of several different wastes occurs in a different nedium (e.g., soil) or matrix (BDAT standards may be :stablished for specified matrices, such as wastewaters, 10nwastewaters, or both) from what is specified for a rarticular restricted waste code or contains ncompatible waste constituents, use of BDAT may not ie appropriate for that waste, and therefore, the LDRs

NOTE: If the LDRs are determined to be relevant and appropriate requirements for a CERCLA action (i.e., there is a close match between the CERCLA and LDR objectives, and a close match between the constituents/matrix of the CERCLA waste and the constituents/matrix of the relevant RCRA waste code), but the treatment process involved in the remedy does not achieve BDAT levels in the field as anticipated, a Treatability Variance establishing alternate treatment levels should be sought. would not be relevant and appropriate [proposed NCP factor (b)]. It has been the experience of the Superfund program that Treatability Variances are frequently necessary for soil and debris contaminated with a restricted RCRA waste (see Superfund LDR Guide \#6A), because the promulgated LDR standards are based on treating less complex matrices of industrial process wastes. As a logical corollary to this finding, the Agency believes that LDRs generally would not be "relevant and appropriate" requirements for soil and debris contaminated with non-RCRA restricted wastes. However, the Agency plans to undertake a rulemaking that will prescribe applicable standards for the treatment of soil and debris contaminated with RCRA-restricted wastes. In the future, these standards may be relevant and appropriate to the treatment of soil and debris contaminated with non-restricted wastes.

Examples illustrating the relevant and appropriate determination process follow:

- A number of drums contairing hazardous wastes are discovered during a site investigation. Although no written documentation or specific knowledge of the source is availabic to identify with certainty the origins of the wastes, the laboratory analyses indicate that they contain very high concentrations of a predominantly liquid waste indicative of industrial waste streams. Therefore, maximum destruction of the drum contents is established as the remedial action objective. Due to the general similarity of the bulk liquids to the spent solvents listed in the F001-F005 waste codes, the CERCLA site manager determines that use of incineration (one of the BDAT identified in the solvent and dioxin rule for that family of waste codes) would be technically suitable. Therefore, the LDRs would be relevant and appropriate for an alternative involving the treatment and placement of the drummed waste.

- A CERCLA waste mixture from an unknown source is found to consist of wastes similar to F021 dioxin-containing wastes (i.e., they contain constituents found in dioxin-containing wastes) and mercury. Because use of incineration -- the BDAT for dioxin-containing wastes -- would not be compatible with a waste also containing mercury, application of the LDR treatment standards to this waste mixture would not be appropriate. Therefore, the LDRs would not be relevant and appropriate to a CERCLA response involving the placement of this waste mixture. (Alternate methods of treating the waste might still be necessary to satisfy both the CERCLA statutory requirement to utilize treatment to the maximum extent practicable and the program expectations that are outlined in the proposed NCP.) 


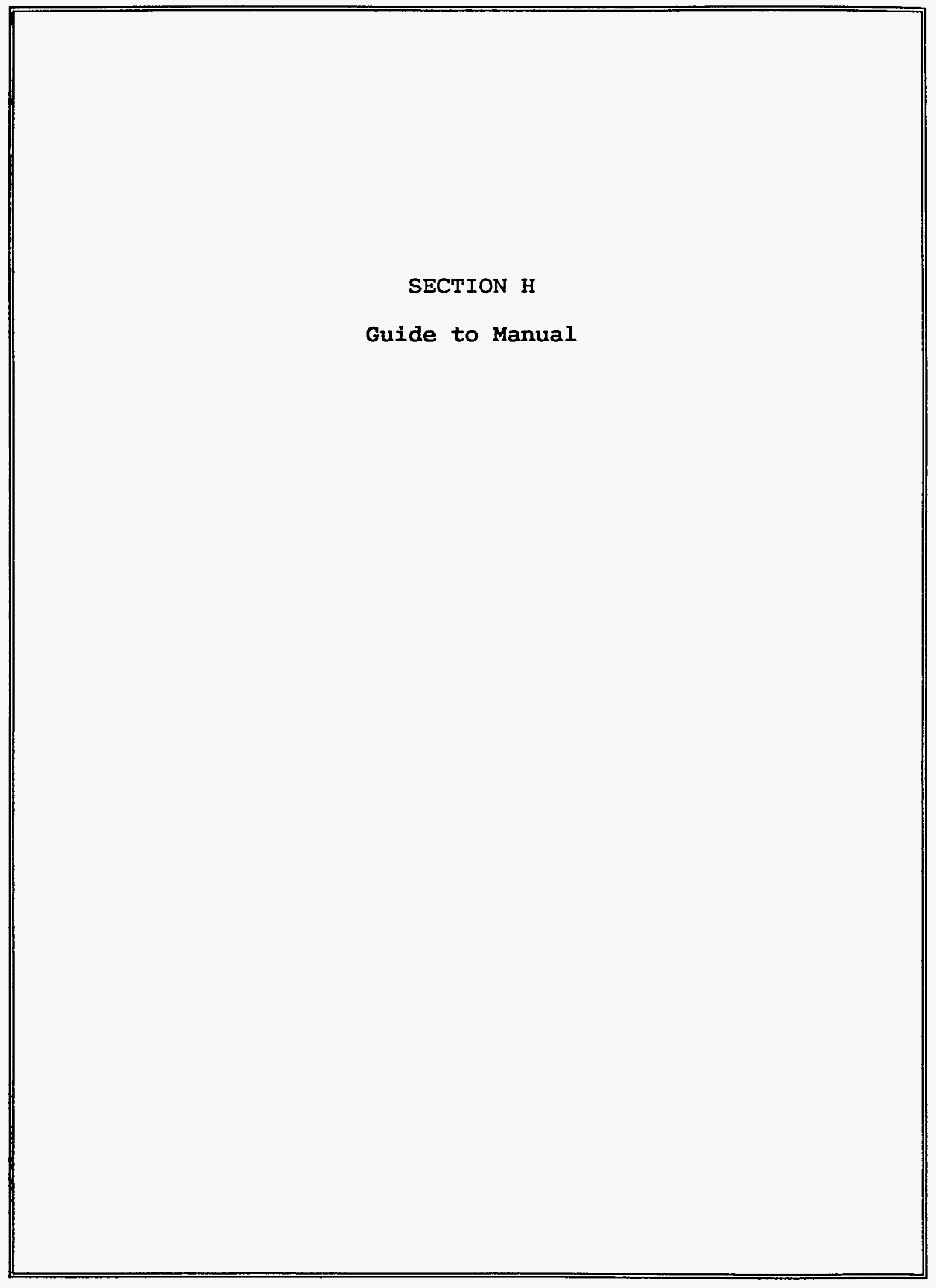




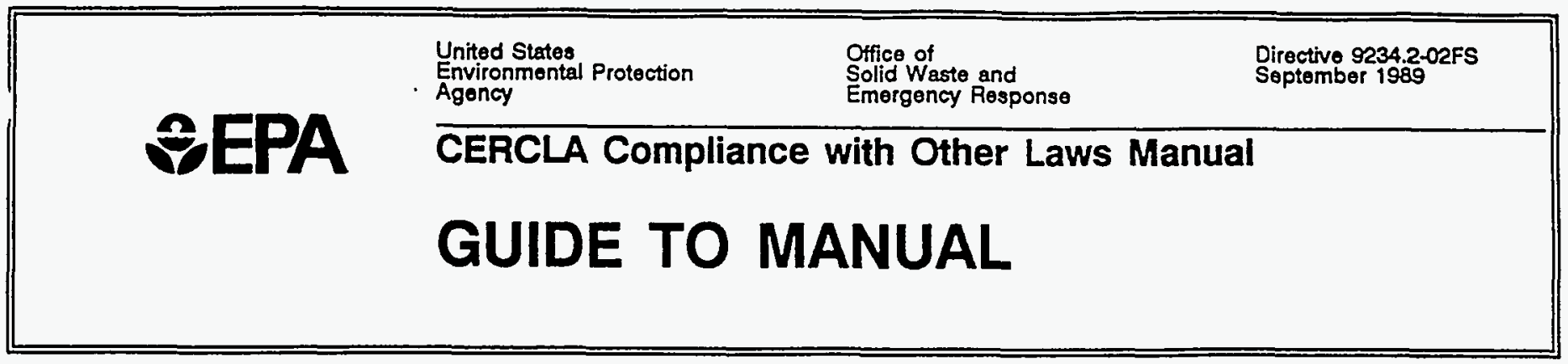

The 1986 Superfund Amendments and Reauthorization Act (SARA) adopts and expands a provision in the 1985 National Contingency Plan (NCP) that remedial actions must at least attain applicable or relevant and appropriate requirements (ARARs). Section 121(d) of CERCLA, as amended by SARA, requires attainment of Federal ARARs and of State ARARs in State environmental or facility siting laws when the State requirements are promulgated, more stringent than Federal laws, and identified by the State in a timely manner. Under EPA regulation and policy, removal actions must comply with ARARs to the extent practicable.

To implement the ARARs provision, EPA has developed guidance, CERCLA Compliance with Other Laws Manual: Parts I and II (OSWER Directives 9234.1-01 and 9234.1-02, respectively). EPA is preparing a series of short fact sheets that summarize the guidance document (OSWER Directives 9234.2 series). This Fact Sheet provides a guide to the compliance manual. The compliance manual is based on policies set forth in the proposed December 21, 1988 revisions to the NCP. The final NCP may adopt policies different from those covered here and should, when promulgated, be considered the authoritative source.

\section{PURPOSE OF MANUAL}

The CERCLA Compliance with Other Laws Manual is intended to assist in the identification and evaluation of ARARs for removal and remedial actions. The manual provides guidance to Remedial Project Managers, On-Scene Coordinators, State personnel, and others responsible for or assisting in response actions under sections 104, 106, and 122 of CERCLA The manual is also intended to assist in the selection of onsite remedial actions that meet the ARARs of the Resource Conservation and Recovery Act (RCRA), the Clean Water Act (CWA), the Safe Drinking Water Act (SDWA), the Clean Air Act (CAA), the Toxic Substances Control Act (TSCA), the Federal Insecticide, Fungicide, and Rodenticide Act (FIFRA), and other Federal and State environmental laws, as required by CERCLA section 121. In general, different ARARs for a site and its remedial action will be identified at various points in the remedy selection process.

\section{DEFINITIONS OF ARARS}

A requirement under other environmental laws may be either "applicable" or "relevant and appropriate," but not both. Identification of ARARs must be done on a site-specific basis and involves a two-part analysis: first, a determination of whether a given requirement is applicable; then, if it is not applicable, a determination of whether it is nevertheless both relevant and appropriate.

\section{DEFINTTIONS:}

- Applicable requirements are those cleanup standards, standards of control, and other substantive environmental protection requirements, criteria, or limitations promulgated under Federal or State law that specifically address a hazardous substance, pollutant, contaminant, remedial action, location, or other circumstance at a CERCLA site.

- Relevant and appropriate requirements are those same standards mentioned above that while not "applicable" at the CERCLA site, address problems or situations sufficiently similar to those encountered at the site that their use is well suited to the particular site.

On-site actions are required to comply with ARARs, but must comply only with the substantive parts of an applicable or relevant and appropriate requirement. Off-site actions must comply only with legally applicable requirements, but must comply fully with both substantive and administrative requirements. 


\section{CONTENTS OF MANUAL}

Part I describes general procedures for identifying ARARs and complying with ARARs in RCRA, CWA, SDWA, and ground-water policies. Part I is organized as follows:

- Chapter 1, General Procedures for CERCLA Compliance with Other Statutes - defines the terms "applicable" and "relevant and appropriate," describes general procedures for identifying and analyzing requirements, identifies waivers from ARARs, and provides matrices listing types of potential ARARs from RCRA, CWA, and SDWA

- Chapter 2, Guidance for CERCLA Compliance with RCRA - discusses RCRA hazardous waste requirements and policies for determining when RCRA requirements are ARARs for CERCLA actions, including what actions at a CERCLA site constitute "disposal," as defined by RCRA.

- Chapter 3, Guidance for Compliance with Clean Water Act Requirements - provides guidance for compliance with CWA substantive requirements for direct discharges, indirect discharges, and dredge-and-fill activities.

- Chapter 4, Guidance for Compliance with Requirements of the Safe Drinking Water Act provides guidance for compliance with SDWA requirements that may be ARARs, including drinking water standards and the requirements for underground injection control, sole-source aquifers, and the wellhead protection program.

- Chapter 5, Ground Water Protection Policies discusses ground-water classification, provides guidance on consistency with policies for groundwater protection, and includes a hypothetical scenario for illustrating how ARARs are identified and used.

- Appendix A provides an overview of the major environmental statutes and regulations covered in Part I.

Part II of the manual describes general procedures for complying with ARARs in CAA, TSCA, FIFRA, other resource protection statutes, mining waste statutes, and State ARARS. Part II is organized as follows:

- Chapter 1, Introduction and Overview - provides an introduction and overview of Part II of the guidance manual and includes matrices of potential ARARs covered in Part II.
- Chapter 2, Clean Air Act Requirements and Related RCRA and State Requirements - provides guidance for compliance with CAA requirements (including the National Ambient Air Quality Standards, the National Emissions Standards for Hazardous Air Pollutants, and the New Source Performance Standards) and related RCRA and State requirements for air emissions.

- Chapter 3, Standards for Toxics and Pesticides provides guidance for compliance with statutes (i.e., TSCA and FIFRA) that address toxic substances (particularly PCBs) and pesticides.

- Chapter 4, Other Resource Protection Statutes provides guidance for compliance with other resource protection statutes, including the National Historic Preservation Act, the Archeological and Historic Preservation Act, the Endangered Species Act, the Wild and Scenic Rivers Act, the Fish and Wildlife Coordination Act, the Coastal Zone Management Act, and the Wilderness Act.

- Chapter 5, Standards, Advisories, and Guidance for the Management of Radioactive Waste discusses potential ARARs and potentially useful guidance for cleaning up radioactively contaminated sites and buildings. Major acts discussed include the Uranium Mill Tailings Radiation Control Act, the Atomic Energy Act, the Nuclear Waste Policy Act, CAA, and CWA.

- Chapter 6, Potential ARARs For CERCLA Actions at Mining, Milling, or Smelting Sites provides guidance for compliance with statutes incorporating standards for mining, milling, or smelting sites, including the Surface Mining Control and Reclamation Act and RCRA.

- Chapter 7, CERCLA Compliance with State Requirements discusses eligibility requirements for State programs, specific types of State laws (e.g., siting requirements), and procedures for communicating State ARARs.

- Appendix A provides guidance for compliance with CAA Part $C$ requirements under the Prevention of Significant Deterioration program.

- Appendix B describes Federal/State relationships under major Federal environmental statutes, including whether the statute allows for State authorization of the program and whether the State provisions are identical or more stringent than the Federal requirements. 


\section{SECTION I \\ CERCLA Compliance with State Requirements}




\section{United States Environmental Protection

The 1986 Superfund Amendments and Reauthorization Act (SARA) adopts and expands a provision in the 1985 National Contingency Plan (NCP) that remedial actions must at least attain applicable or relevant and appropriate requirements (ARARs). Section 121(d) of CERCLA, as amended by SARA, requires attainment of Federal ARARs and of State ARARs in State environmental or facility siting laws when the State requirements are promulgated, more stringent than Federal laws, and identified by the State in a timely manner.

To implement the ARARs provision, EPA has developed guidance, CERCLA Compliance With Other Laws Manual: Parts I and II (Publications 9234.1-01 and 9234.1-02). EPA is preparing a series of short fact sheets that summarize these guidance documents. This fact sheet provides a guide to Chapter 6 of Part II, which addresses CERCLA compliance with State requirements. The material covered here is based on SARA and on policies in the proposed revisions to the NCP. The final NCP may adopt policies different from those covered here and should, when promulgated, be considered the authoritative source.

\section{INTRODUCTYON TO STATE ARARs}

Prior to SARA, the NCP classified all State requirements as criteria that EPA should consider when selecting a remedy. The amendments elevated to the level of potential ARARs any "promulgated" State requirements that are "more stringent" than Federal requirements (see Highlight 1 for specific criteria).

\section{Highlight 1: CRITERIA FOR A STATE REQUIREMENT TO QUALIFY AS AN ARAR}

In order to qualify as a State ARAR, a State requirement should be:

\section{- A State law;}

An environmental or facility siting law;

Promulgated;

More stringent than the Federal requirement;

- Identified in a timely manner; and

Consistently applied.
State requirements, like Federal requirements, must also be substantive in nature to qualify as ARARs. Administrative or procedural State requirements are not ARARs. Elements of State ARARs are discussed below.

Generally, laws and regulations adopted at the State level, as distinguished from the regional, county, or local level, are considered to be State ARARs. Local laws in themselves are not ARARs. However, requirements that are developed by a local or regional body and are both adopted and legally enforceable by the State may be potential State ARARs. Potential State ARARs may also be found where local or regional boards have established standards that become part of a legally enforceable State "plan."

\section{STATE ENVIRONMENTAL OR FACILITY SITING LAWS AS ARARS}

Several common types of State statutes that may provide State ARARs are described below. Guidance on compliance with these requirements is provided.

\section{A. State Siting Requirements (Location Standards)}

State siting requirements may restrict the location of existing and expanding or new hazardous waste treatment, storage, and disposal (TSD) facilities (Highlight 2 provides the triggers for State siting 
requirements). Siting restrictions have generally been left to the States to implement. However, the Resource Conservation and Recovery Act (RCRA) contains limited siting provisions that restrict locations in fault zones, 100 year floodplains, salt dome and salt bed formations, and underground caves. As of 1987, 33 States had promulgated siting requirements that were more stringent than Federal requirements. ${ }^{1}$

\section{Highlight 2: TRIGGERS FOR STATE SITING REQUIREMENTS}

State siting requirements may be triggered as potential ARARs when:

- An existing hazardous waste site is in a restricted location, and a corresponding action is required (such as a removal, remediation, design, or modified care);

- A new hazardous waste unit is to be created in a restricted location; or

- A non-land-based unit is brought on-site.

The application of a State siting law to a Superfund action also depends upon the State's definition of a "new" or "existing" site. Because Superfund sites generally represent pre-existing (and unplanned) situations, State restrictions for new or operating facilities may not apply to Superfund sites.

State siting requirements are commonly found in State laws that address environmentally sensitive areas such as wetlands, endangered species habitats, gamelands, parks, preserves, and underground mining/subsidence areas. States also protect ground water and surface water through a variety of location standards such as: (1) prohibitions of facilities in certain locations; (2) quantitative setback distances from water supplies or other water bodies; (3) quantitative thickness or hydraulic conductivity in soil barriers; and (4) designation of acceptable soil or rock type for facility siting. Finally, buffer zones may also contain location standards ranging from specific setback distances to general statements that preclude interference with population areas.

\section{B. Discharge of Toxic Pollutants to Surface Waters}

The Clean Water Act (CWA) requires States to identify water bodies that may be adversely affected by toxic pollutants and to develop criteria to protect these areas. State toxic pollutant regulations are generally pre-

\footnotetext{
$T$ Temple, Barker, and Sloane, Inc., Review of State Hazardous Waste Facilitv Criteria. Revised Draft Final Report. U.S. EPA, Washington, DC, 1987
}

sented in the form of narrative goais rather than numc. criteria. For example, State narrative requirements may be expressed in terms predicated upon specific toxicity testing procedures or in terms of whole effluent toxicity limits. All substantive aspects of these narrative requirements may be ARARs for CERCLA discharges. In addition, general prohibitions on toxic pollutant discharges of known carcinogens may be State ARARs for on-site CERCLA discharges. All such State requirements should be examined for any exemptions of Federal activities.

\section{Antidegradation Requirements for Surface Water}

The CWA requires all States to adopt statutes or regulations that prevent the degradation of high-quality waters. In addition, States may have promulgated other antidegradation requirements for surface waters (see Highlight 3 for typical State antidegradation requirements).

\section{Highlight 3: TYPICAL STATE ANTIDEGRADATION REQUIREMENTS}

Typical State antidegradation requirements will mandate the:

- Maintenance of existing in-stream designated beneficial uses;

- Maintenance of high-quality waters unless the State decides to allow limited degradation where economically or socially justifiable;

- Maintenance of the quality of Outstanding National Resource Waters (ONRW); and

- Use of best available technology for treatment of new or increased pollution into high-quality waters.

If a CERCLA remedial action involves a point-source discharge of treated effluent to high-quality surface waters, these various State antidegradation requirements may be ARARs for the discharge.

\section{Antidegradation Requirements for Ground Water}

Like antidegradation requirements for surface water, antidegradation requirements for ground water are generally prospective in nature and are designed to prevent further degradation of water quality. If a Str has developed antidegradation requirements for grou water, CERCLA remedial actions involving injection $\omega_{1}$ partially treated water into a pristine aquifer may be affected. These State requirements would not, however, require cleanup to the aquifer's original quality prior to contamination. However, there may be a State cleanup 
law that specifically requires cleanup to background, which would constitute an ARAR for the remediation.

\section{III. "PROMULGATED" LAWS AS ARARs}

A State requirement must be promulgated to qualify as an ARAR. A State requirement is promulgated if it is: (1) legally enforceable; and (2) of general applicability (see Highlight 4).

\section{Highlight 4: "PROMULGATED STATE LAWS}

- Legal Enforceability: State requirements may be legally enforceable in several ways. State statutes or regulations may either: (1) have their own specific enforcement provisions written into them; or (2) be enforced through the State's general legal authority.

- General Applicability: State requirements must apply to a broader universe than Superfund sites. For example, a State requirement having general applicability ("of general applicability") would apply to all hazardous waste sites in the State that meet the jurisdictional prerequisites of the requirement, not just to CERCLA sites.

Promulgated requirements are found in State statutes and regulations that have been adopted by authorized State agencies. Statute numbers, enactment dates, and effective dates may indicate whether the requirements have been promulgated. Such promulgated requirements may be either numerical or narrative in form.

\section{A. Criteria That Are "To Be Considered" (TBCs)}

Although they are not ARARs, State advisories, guidance and policies, etc., may help EPA define and develop protective remedies and interpret State laws. These State policies and guidance, known as "to be considered" (TBCs), are not potential ARARs because they are neither promulgated nor enforceable. It may be necessary to consult TBCs to interpret ARARs or to determine preliminary remediation goals when ARARs do not exist for particular contaminants. States should identify or communicate to EPA TBCs that they consider to be pertinent to the remedy.

\section{B. Narrative Standards}

Occasionally, a State may submit as an ARAR a narrative State statute. While narrative State statutes may be ARARs, unpromulgated methodologies that are designed to implement narrative statutes are not. EPA has discretion to determine whether numbers obtained from unpromulgated methodology should be met, or whether they constitute TBCs. It is important to note, however, that numbers derived from State narrative statutes may be
ARARs if the narrative statute is an ARAR, and has implementing regulations that are also ARARs.

\section{IV. "MORE STRINGENT" LAWS AS ARARS}

CERCLA requires remedies to comply with State requirements that are more stringent than Federal requirements (see Highlight 5 for a definition of "more stringent").

\section{Highlight 5: 'CRITERIA FOR "MORE STRINGENT"}

- State requirements are more stringent than Federal requirements if the State program has Federal authorization and the State requirements are "at least" as stringent.

- State programs that do not have a Federal counterpart are generally more stringent because they add new requirements.

- Stringency comparisons may be necessary if a State program is not Federally authorized but has a Federal counterpart.

It is important to note that EPA believes that if a State is authorized to implement a program in lieu of a Federal agency, State laws arising out of that program constitute the ARARs instead of the Federal authorizing legislation. A stringency comparison is unnecessary because State regulations under Federally authorized programs are considered to be Federal requirements.

\section{IDENTIFYING AND COMMUNICATING STATE ARARS IN A TIMELY MANNER}

CERCLA requires States to identify ARARs in a timely manner. As a result, EPA and a State may enter into a Superfund Memorandum of Agreement (SMOA) which, among other things, establishes a schedule for communicating ARARs. In the absence of a SMOA, States must identify ARARs within certain timeframes (identified below) in order for that identification to be considered "timely". EPA is not legally required to consider potential State ARARs that are not identified within these timeframes. The responsibilities of a State to communicate ARARs will vary depending upon its role at the site (see Highlight 6 for State roles and responsibilities).

\section{A. Critical Points for Identifying State ARARs}

There are particular points in the preremedial and remedial processes during which the lead and support agencies must communicate with each other. SMOAs may identify timeframes for communicating potential ARARs. Highlight 7 presents the critical points in the 


\section{Highlight 6: STATE ROLES AND RESPONSIBILITIES}

As the support agency, the State is responsible for:

- Receiving and reviewing information about proposed Federal ARARs and TBCs, as early as site characterization;

- Coordinating State input on ARARs from all State agencies;

- Identifying State ARARs during the RIFS;

- Justifying proposed State ARARs; and

- Reviewing ARARs identified in the proposed plan and ROD.

As the lead agency, the State is responsible for:

- Requesting EPA's identification of Federal ARARs;

- Identifying State ARARs during the RI/FS;

- Identifying ARARs and waivers in the proposed plan; and

- Documenting compliance with ARARs in the draft ROD.

pre-remedial and remedial processes if no SMOA exists, or if the SMOA fails to address such timeframes. It is important to note that regardless of their role, EPA and the States each have an unvarying responsibility. States are alwavs responsible for identifying State ARARs and communicating them to EPA in a timely manner. EPA is always responsible for making the final determination on ARARs as part of remedy selection, regardless of who conducts the RI/FS (i.e., EPA, the State, or PRP), or who recommends the remedy (i.e., EPA or the State), except for State-lead non-Fund-financed sites.

\section{B. EPA Responsibilities for Communicating Waivers}

If EPA intends to waive any State-identified ARARs in its proposed plan, or does not agree with the State that a certain State standard is an ARAR, it must formally notify the State either: (1) when the Agency submits the RI/FS for State review; or (2) when the Agency responds to the State's submission of the RI/FS. In addition, EPA must respond to State comments on waivers from, or disagreements about, State ARARs after making the RI/FS and proposed plan available for public comment.
Highlight 7: CRITICAL POINTS FOR IDENTIFYING ARARS

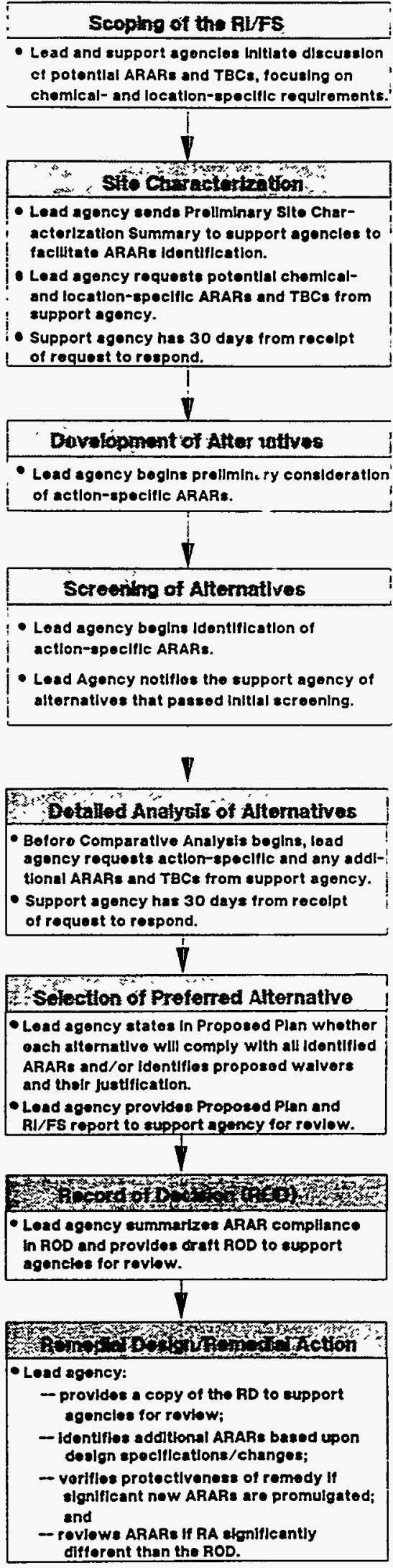


C. State Responsibilities for Documenting State ARARs

To demonstrate that the State requirement is an ARAR, States are required by the NCP to provide citations to the statute or regulation number. In addition, States should provide the requirement's effective date and description of scope, where appropriate. Furthermore, States should provide evidence that the requirement is more stringent than the Federal requirement. 'Finally, States should also describe in writing the relationship between the State requirement and the site or action, to show that the State requirement is applicable or relevant and appropriate to that particular site or action.

\section{STATE STANDARD WATVERS}

\section{A. Statutory Waivers}

Of the six ARAR waivers set forth in CERCLA, one applies exclusively to State ARARs: inconsistent application of the State standard by the State. This waiver may be invoked when evidence exists that a State standard has not been or will not be consistently applied to both non-NPL and NPL sites within the State. The waiver may be used, for example, for a State standard that was promulgated but never applied, or for a standard that has been variably applied or enforced. A State standard is presumed to have been consistently applied unless there is evidence to the contrary.

\section{B. State Waivers}

In addition to the waivers provided by CERCLA, many State regulations have their own waivers or exceptions to their requirements. When a State requirement has a waiver that is applicable, the State requirement does not have to be met. EPA makes the final determination as part of the selection of remedy.

State waivers are common components of State siting requirements. Usually only temporary or emergency situations qualify for waivers of State siting requirements. Remedial actions at Superfund sites may qualify for State waivers depending upon their design and the particular waiver requirements. To determine if a remedial action qualifies for a State waiver, the State waiver provision should be examined for its duration, circumstances that justify its use, and any renewal provisions.

\section{State-Wide Bans}

Under CERCLA section 121(d), a State-wide ban prohibiting land disposal of hazardous substances is not an ARAR unless the following three criteria are met:

- The State requirement is of general applicability and was adopted by formal means;

- The State requirement was idopted on the basis of hydrologic, geologic, or other relevant considerations and was not adopted for the purpose of precluding on-site remedial actions or other land disposal for reasons unrelated to protection of human health and the environment; and

- The State arranges for, and assures payment of the incremental costs of, utilizing a facility for hazardous waste disposal. 


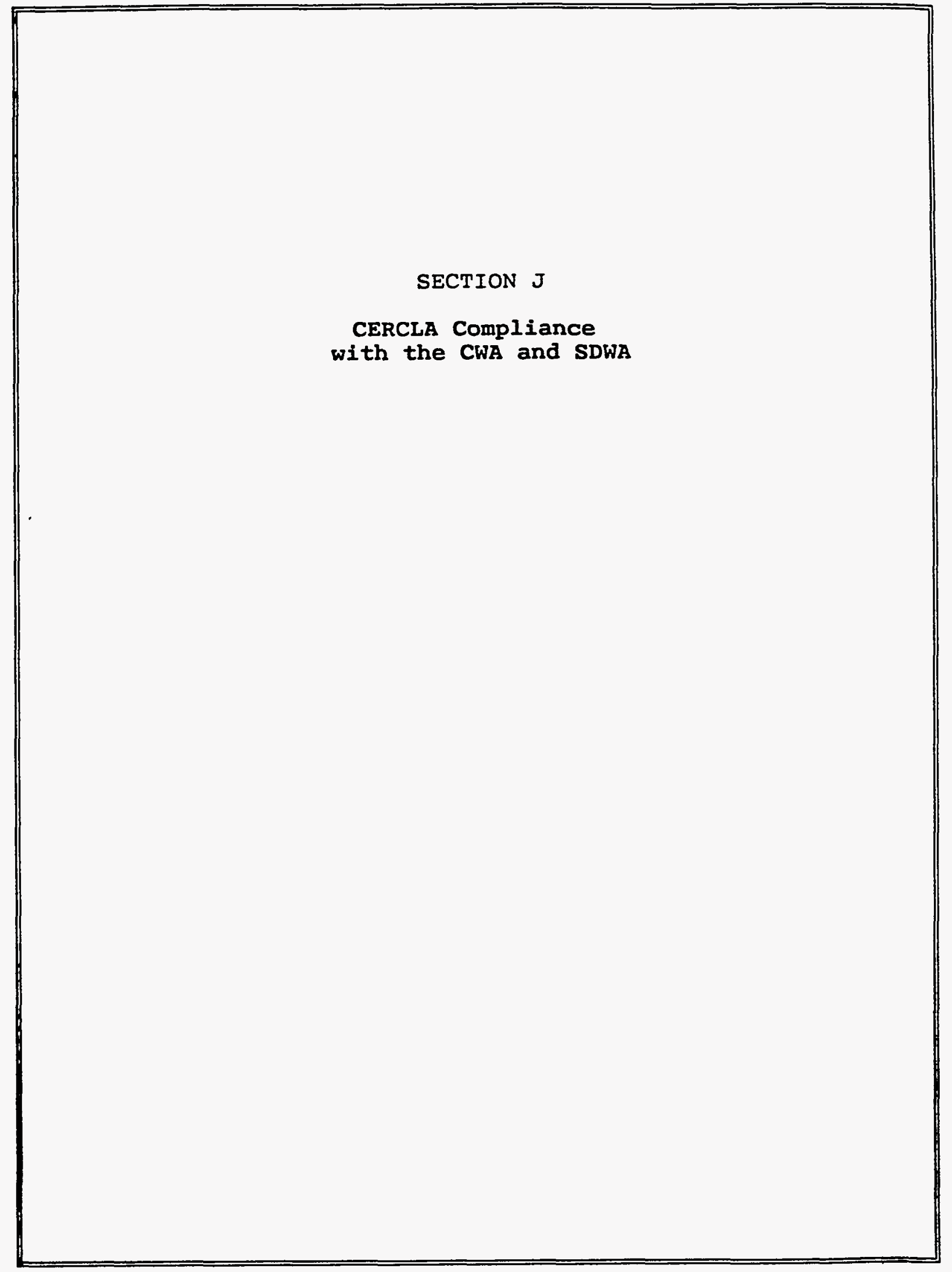




\section{United States \\ Environmental Protection \\ Office of \\ Solid Waste and \\ Emergency Response \\ Publication 9234.2-06/FS \\ February 1990 \\ CERCLA Compliance With Other Laws Manual \\ SEPA \\ CERCLA Compliance \\ with the CWA and SDWA}

Office of Emergency and Remedial Response

Office of Program Management OS-240

Quick Reference Fact Sheet

The 1986 Superfund Amendments and Reauthorization Act (SARA) adopts and expands a provision in the 1985 National Contingency Plan (NCP) that remedial actions must at least attain applicable or relevant and appropriate requirements (ARARs). Section 121(d) of CERCLA, as amended by SARA, requires attainment of Federal ARARs and of State ARARs in State environmental or facility siting laws when the State requirements are promulgated, more stringent than Federal laws, and identified by the State in a timely manner.

To implement the ARARs provision, EPA has developed guidance, CERCLA Compliance With Other Laws Manual: Parts I and II (Publications 9234.1-01 and 9234.1-02). EPA is preparing a series of short fact sheets that summarize these guidance documents. This Fact Sheet focuses on CERCLA compliance with the Clean Water Act and the Safe Drinking Water Act (Chapters 3 and 4, respectively, in Part I). In addition, it discusses other statutes with provisions relevant to surface water or drinking water, such as dredge-and-fill requirements. The material covered here is based on SARA and on policies in the final revised NCP.

\section{Compliance With The Clean Water Act}

A primary purpose of the Clean Water Act (CWA), also known as the Federal Water Pollution Control Act, is to restore and maintain the quality of surface waters. The CWA regulations that are most likely to be ARARs for Superfund actions are the requirements for: (1) surface-water quality; (2) direct discharges to surface waters; (3) indirect discharges to publicly-owned treatment works (POTWs); or (4) discharges of dredge-and-fill materials into surface waters (including wetlands). Pollutants are regulated under the CWA according to their category (see Highlight 1 ).

\section{A. CWA DIRECT DISCHARGE REQUIREMENTS (NPDES)}

The CWA controls the direct discharge of pollutants to surface waters through the National Pollutant Discharge Elimination System (NPDES) program. NPDES requires permits for direct discharges to surface waters. The permits contain limits based upon either effluent (discharge) standards, or, if they are more stringent, ambient (overall water quality) standards. NPDES permits are issued, monitored, and enforced by $E P A$, or by a State agency authorized by EPA to administer an equivalent State program.

\section{Highlight 1: CATEGORIES OF POLLUTANTS}

- Toxic pollutants -- the 126 individual priority toxic pollutants contained in 65 toxic componnds or classes of compounds (including organic pollutants and metals) adopted by EPA pursuant to the CWA section 307(a)(1);

Conventional pollutants -the poliutants classified as bioctemical oxygen demand (BOD), total suspended solids (ISS), fecal colform, oil and grease, and $\mathrm{gH}$ pursuant to he CWA section $304(a)(4)$ and

- Nonconventional pollutants - any pollutant not ideritified as either conventional or toxic in accordance with 40 CFR section $122.21(1)(2)$.

An on-site discharge from a CERCLA site to surface waters must meet the substantive NPDES requirements, but need not obtain an NPDES permit nor comply with the administrative requirements of the permitting process, consistent with CERCLA section 
121(e)(1). On the other hand, an off-site discharge from a CERCLA site to surface waters is required to obtain an NPDES permit and to meet both the substantive and the administrative NPDES requirements. (See Highlight 2 for CERCLA activities considered to be direct discharges.) Occasionally, more than one CWA direct discharge requirement may potentially apply to a surface-water cleanup (see Section III for resolution of this issue).

\section{Highlight 2: CERCLA ACTIVTTIES CONSIDERED TO BE DIRECT DISCHARGES}

\section{From a Point Source:}

- On-site Waste Treatment: wastewater is discharged from a treatment plant directly into, or in very close proximity to, a surface-water body through a discernible conveyance such as a pipe, ditch, channel, tunnel, or well.

- Off-site Treatment: wastewater from the site is piped or otherwise discharged through a discernible conveyance to an off-site surfacewater body.

- Any Remedial Action: site runoff is channeled directly to a surface-water body through a ditch, culvert, storm sewer, or other means.

\section{From a Nonpoint Source:}

- Unchanneled runoff from a site into surface water.

\section{Substantive Requirements}

\section{a. Ambient Water Quality Standards}

Federal Water Quality Criteria (WOC) - Federal WQC are non-enforceable guidelines that set concentrations of pollutants which, when published, were considered adequate to protect surface waters. The WQC may be relevant and appropriate 'to CERCLA cleanups based upon an evaluation of four criteria set forth in CERCLA section 121(d): (1) uses of the receiving water body; (2) media affected; (3) purposes of the criteria; and (4) current information. Under CWA section 304, EPA has developed WQC for: (1) protection of human health; and (2) protection of aquatic life.

State Antidegradation Requirements/Use Classifications - Under the CWA, every State is required to classify all of the waters within its boundaries according to its intended use. EPA regulation requires States or establish antidegradation requirements. As a rest discharges that result from CERCLA response actions in high-quality receiving waters could be prohibited or limited, unless an ARAR waiver (such as inconsistent application by the State) is available. State antidegradation requirements may be applicable to both point and nonpoint source discharges. (A point source is a discernible conveyance such as a pipe, ditch, channel, tunnel or well from which pollutants may be discharged.)

\section{b. Effluent Standards}

Technology-Based Limitations - CWA section 301(b) requires that, at a minimum, all direct discharges meet technology-based limits. Technology-based requirements for conventional pollutant discharges include application of the best conventional pollutant control technology (BCT). For toxic and nonconventional pollutants, technology-based requirements include the best available technology economically achievable (BAT). Because there are no national effluent limitations regulations for releases from CERCLA sites, technology-based treatment requirements are determined on a case-by-case basis using best professional judgment (BPJ) to determine BCT/BAT equivalent discharge requirements. Technology-based limits for water discharges are often expressed as co' centration levels. Technology-based limits are applical to direct discharges from a point source.

State Water Quality Standards (WOS) - Under CWA section 303, States must develop water quality standards. State WQS may be numeric or narrative. Where State WQS are narrative, either the whole-effluent or the chemical-specific approach is generally used as the standard of control. State WQS may be applicable to both point and nonpoint source discharges.

\section{Administrative Requirements}

An off-site direct discharge from a CERCLA response action to surface waters requires an NPDES permit. The requirements for obtaining a permit include:

- Certification Requirements: the applicant for an NPDES permit must receive certification from the State that the discharge will be in compliance with CWA sections $301,302,303,306$, and 307 ;

- Permit Application Requirements: an application for an NPDES permit for a new discharge must be made 180 days prior to the actual discharge; pollution control equipment must be install before the new discharge begins; and compliar must be achieved within the shortest feasible time, not to exceed 90 days; 
- Reporting Requirements: the NPDES permit requires a discharger to maintain records and to report periodically on the amount and nature of pollutants in the discharged wastewaters; and

- Public Participation Requirements: the NPDES discharge limitations and requirements developed for a CERCLA site are subject to public participation requirements, including public notice and public comment.

\section{B. CWA INDIRECT DISCHARGE REQUIREMENTS} (Pretreatment Program for Nondomestic Users of POTWs)

Under CWA, all discharges by nondomestic users into POTWs must meet pretreatment standards. The purpose of pretreatment standards is to avoid the introduction of pollutants into municipal wastewater treatment plants that pass through, interfere with, or are otherwise incompatible with, such treatment works. The pretreatment standards are found in the national pretreatment program and in all State and local pretreatment regulations. There are three types of pretreatment standards (see Highlight 3).

Any discharge from a CERCLA site to a POTW is considered an off-site activity. It is, therefore, subject to both the substantive and administrative requirements of the national pretreatment program, and to all applicable State and local pretreatment regulations.

\section{Highlight 3 TYPES OF PRETREATMLAT} STANGTODS

Prohibited discharge standards apply to all nondomestic discharges ond profíbit polintants that cause fire or explosions, corrosion, obstructions high temperatures at TOTWs problems with workér heallif ano safety, or interference.

Caterorical phetreatrient, stanifintas are national, technology based effuetit limitations lese toper by EPA for certinin industrial ategories Currently tro ha fional standards estist or. CERO $\mathrm{A}$ dischanges.

Local linits are de edoped by quatifyng POOWs ana are designed to ensure conplatance on specific environmental standards and criterna at the local level

\section{Discharge of CERCLA Wastewater to a POTW}

Wastewater from a CERCLA site may be sent to a POTW that either has or does not have an EPAapproved pretreatment program. A POTW with an approved pretreatment program already has the mechanisms necessary to ensure that discharges, including those from a CERCLA site, comply with applicable pretreatment standards and requirements. Remedial Project Managers (RPMs) must evaluate a POTW without an approved pretreatment program to determine whether it has sufficient mechanisms for meeting the requirements of the national pretreatment program when accepting CERCLA wastewater.

The determination of whether the POTW can accept CERCLA wastewater should be made during the RI/FS stage of the remedial action. Factors for determining a POTW's ability to accept CERCLA wastewater include:

- The quantity and quality of the CERCLA wastewater and its compatibility with the POTW;

- The impacts of a CERCLA discharge on the POTW's treatment system and on its continued compliance with its NPDES permit;

- The POTW's record of compliance with its NPDES permit and pretreatment program requirements to determine if the POTW is a suitable disposal site for the CERCLA wastewater;

- The potential for volatilization of the wastewater constituents at the CERCLA site, while moving through the sewer system, or at the POTW, and its potential impact on air quality;

- The potential for ground-water contamination from the transport of the CERCLA wastewater or impoundment at the POTW, and the need for ground-water monitoring;

- The potential effect of the CERCLA wastewater upon the POTW's. discharge as evaluated by maintenance of water quality standards in the POTW's receiving waters;

- The POTW's knowledge of and compliance with any RCRA requirements or requirements of other environmental statutes; and

- The various costs of managing the CERCLA wastewater, including all risks, liabilities, permit fees, etc.

In addition to these factors, off-site discharges of CERCLA wastewaters may only be made to facilities (generally POTWs) in compliance with the CERCLA offsite policy (OSWER Directive 9834.11, November 1987, 
at p. 11; see also $40 \mathrm{CFR} 300.440$ (proposed), 53 FR 48218 , November 29, 1988).

2. Applicable POTW Control Mechanisms (Permits or Orders)

It is likely that RPMs will have to obtain from POTWs permits or orders for CERCLA remedies involving indirect discharges to such POTWs. POTWs have the authority to limit or reject wastewater discharges and to require dischargers to comply with control mechanisms such as permits or orders. These permits or orders contain applicable pretreatment standards including local discharge prohibitions and numerical discharge limits. In addition to incorporating pretreatment limitations and requirements, the control mechanisms may also include: (1) monitoring and reporting requirements to ensure continued compliance with applicable pretreatment standards; (2) spill prevention programs to prevent the accidental discharge of pollutants to POTWs (e.g., spill notification requirements); and (3) other requirements.

\section{DREDGE-AND-FILL REQUIREMENTS}

Any discharge of dredge-and-fill material into the navigable waters of the United States, including wetlands, is subject to the requirements of certain regulatory authorities (see Highlight 4). These requirements ensure that impacts on aquatic ecosystems are evaluated. CERCLA activities that may be considered dredge-andfill activities include, but are not limited to, the following:

- Dredging of contaminated lake, river, or marine sediments;

- Disposal of contaminated soil, waste material, welldrilling materials, or dredged material in surface water, including most wetlands;

- Capping of a site containing wetlands;

- Construction of berms and levees to contain wastes;

- Stream channelization; and

- Excavation to contain effluent.

\section{COORDINATION BETWEEN SUPERFUND AND WATER OFFICES}

RPMs are required to identify potential CWA ARARs when considering a discharge to surface waters, a discharge to a POTW, or dredging of surface-water sediments. In order to identify and communicate ARARs in a timely manner, each EPA Region should establish procedures between the Regional Superfund and Water offices. The Superfund and the Water offices should coordinate their activities at the following stages of the remedy selection process:

\section{Highlight 4: DREDGE-AND-FILL AUTHORITIES}

Dredge-and-fill activities are regulated under the following authorities:

- Section 10 of the Rivers and Harbors Act prohibits the unauthorized obstruction or alteration of any navigable water of the United States.

- Section 404 of the Clean Water Act regulates the discharge of dredged or fill material to waters of the United States. It applies to all discharges of dredged or fill material to U.S. waters, regardless of the condition of the wetland. While section 404 , when applicable, requires consideration of any practicable alternatives, there is no duty to mitigate adverse effects from previous dischargers. However, it may be appropriate in some circumstances to protect the environmental values of the site.

- Section 103 of the Marine Protection Research and Sanctuaries Act regulates ocean discharges of materials dredged from waters of the United States.

- 40 CFR Part 6, Appendix A contains EPA's regulations for implementing Executive Order 11990, Protection of Wetlands, and Executive Order 11988, Floodplain Management, which require Federal agencies, wherever possible, to avoid or minimize adverse impacts of Federal actions upon wetlands and floodplains (including dredge-and-fill activities). The proposed plan and selected remedial action should be evaluated in light of these requirements and the alternative modified, if necessary, to avoid or minimize adverse impacts.

- Preliminary Assessment/Site Investigation. For planning purposes, copies of pertinent documents may be sent to the Water offices (Regional and State, if appropriate) to promptly notify them of possible remedial actions involving discharges to surface waters.

- Remedial Investigation/ Feasibility Study. To provide and obtain additional information regardir the site and the potential contamination of 1 surface water, copies of the RI/FS Workplan (dral، and final), the RI/FS Report, and the Proposed Plan may be sent to the Water offices. In addition, close coordination should occur Juring the initial and detailed screening of alternatives. 
- Selection of Remedy/Record of Decision. To ensure that the selected remedy attains all CWA ARARs (or other health- or risk-based levels when ARARs are waived or do not exist) and is adequately documented, the Water offices should be contacted for additional information.
- Remedial Design/Remedial Action. To help ensure that the selected remedy will attain all ARARs, the Water offices should be consulted during the RD/RA

\section{Compliance With The Safe Drinking Water Act}

The Safe Drinking Water Act of 1974 (SDWA), as most recently amended in 1986, requires EPA to establish regulations to protect human health from contaminants in drinking water. To achieve this, EPA has developed: (1) drinking water standards; (2) a permit program for the underground injection of wastes (the Underground Injection Control (UIC) Permit Program); and (3) groundwater protection programs (the Sole Source Aquifer Program and the Wellhead Protection Program).

\section{A. DRINKING WATER STANDARDS}

\section{National Primary Drinking Water Regulations}

The drinking water regulations are applicable to public water systems (defined as systems) having at least 15 service connections or serving at least 25 year-round residents. National primary drinking water regulations consist of contaminant-specific standards known as Maximum Contaminant Levels (MCLs), which are set as close as feasible to Maximum Contaminant Level Goals (MCLGs) (see Highlight 5). "Feasibility" is based upon best technology and it takes cost into consideration.

\section{Highlight 5: DEFINITIONS OF MCLs AND MCLGS}

Maximum Contaminant Levels are enforceable standards that apply to specified contaminants which EPA has determined have an adverse effect on human health above certain levels.

Maximum Contaminant Level Goals are nonenforceable health-based goals that are established at levels at which no known or anticipated adverse effects on the health of persons occur and which will allow an adequate margin of safety,

V CERCLA section 121(d)(2)(A)(i) requires on-site 1 CERCLA remedies to attain standards or levels of control established under the SDWA (i.e., MCLs, where they are applicable or relevant and appropriate). CERCLA section
121(d)(2)(A) also requires on-site remedies to attain MCLGs where relevant and appropriate under the circumstances of the release. EPA believes that MCLGs set at levels above zero should be attained where relevant and appropriate as cleanup levels for ground or surface waters that are current or potential sources of drinking water. If the MCLG is equal to zero, the Agency believes it is not appropriate for setting cleanup levels, and the corresponding $\mathrm{MCL}$ will be the potentially relevant and appropriate requirement. (In some instances, MCLs will also be applicable if the water is delivered through a public water supply system having the requisite number of service connections and year-round customers mentioned above.)

\section{Secondary Drinking Water Regulations}

Secondary drinking water regulations consist primarily of Secondary Maximum Contaminant Levels (SMCLs) for specific contaminants or water characteristics that may affect the aesthetic qualities of drinking water (i.e., color, odor, and taste). SMCLs are nonenforceable limits intended as guidelines for use by States in regulating water supplies. SMCLs are guides for public water systems and are typically measured at the tap of the user of the system. However, SMCLs are potential relevant and appropriate requirements in States that have adopted SMCLs as additional drinking-water standards.

\section{B. UNDERGROUND INJECTION CONTROL PROGRAM (UIC)}

Under the UIC program, owners and operators of certain classes of underground injection wells are required to obtain and adhere to the requirements of operating permits. The permit applicant must prove to the State or Federal permitting authority that operation of the underground injection will not endanger drinking-water sources. For regulatory and reporting purposes, underground injection wells are divided into five categories. Class I, Class IV, and Class V wells are most likely to be associated with CERCLA response actions (see Highlight 6). 


\section{Highlight 6: DESCRIPTION OF CLASS I, IV, AND Y WELIS}

- Class I wells are used to inject industrial, hazardous, and municipal wastes beneath the lower most formation containing, within onequarter mile (1/4) of the well bore, an underground drinking-water source.

- Class IV wells are used to inject hazardous or radioactive waste into or above a formation containing, within one-quarter mile $(1 / 4)$ of the well bore, an underground drinking-water source.

- Class $V$ wells include all wells not incorporated in Classes I through IV, and are typically recharge wells, septic system wells, and shallow industrial (non-hazardous) disposal wells.

An abandoned or failed Class I and Class IV injection well facility could be a site of a CERCLA action, or the CERCLA response action may include the reinjection of treated ground water. In addition, a CERCLA cleanup could involve the reinjection of nonhazardous waste water to a Class $V$ well. In each case, requirements under the UIC program may be potential ARARs.

\section{Substantive Requirements}

\section{a. The SDWA UIC Provisions}

The injection of hazardous wastes from CERCLA sites into wells constructed both on-site or off-site must meet the substantive requirements of the UIC program. In general, no owner or operator may construct, operate, or maintain an injection well in a manner that results in the contamination of an underground source of drinking water at levels that violate MCLs or otherwise affect the health of persons. While the UIC regulations expressiy refer to MCLs (40 CFR Parts 142, 144), non-zero MCLGs will generally be potential relevant and appropriate requirements for CERCLA cleanups involving an on-site injection well containing ground water potentially used for drinking water. In addition, all owners and operators of underground injection wells are subject to UIC closure requirements. Finally, injection of hazardous wastes into a Class I well requires compliance with additional UIC construction, operating, and monitoring requirements.

b. The Resource and Conservation and Recovery I Act (RCRA)

Under section 3020 of RCRA, the injection of hazardous wastes into Class IV injection wells is banned unless: (1) the injection is a CERCLA response action or a RCRA corrective action; (2) the contaminated ground water is treated to substantially reduce hazardous constituents prior to each injection; and (3) the response action or corrective action is sufficient to protect human health and the environment upon completion. Th requirements are potential ARARs for the reinjectic hazardous waste into Class IV wells in a pump-and-treat remediation system.

Because reinjection of treated contaminated ground water at CERCLA sites is specifically addressed in RCRA section 3020, RCRA land disposal restrictions (sections $3004(\mathrm{f})$, (g) and (m)) are not applicable to eachreinjection or to the conclusion of a pump-and-treat remediation. EPA also expects that generally they will not be found to be relevant or appropriate requirements. Therefore, the best demonstrated available technology (BDAT) generally will not have to be met for each reinjection or at the conclusion of a pump-and-treat remediation involving a Class IV well. (See the Don Clay, AA (OSWER), Memorandum on the "Applicability of Land Disposal Restrictions to RCRA and CERCLA Groundwater Treatment Reinjection," December 27, 1989, OSWER Directive 9234.1-06).

RCRA also requires the owner or operator of a Class I UIC well to comply with RCRA corrective action, for releases from solid waste management units, if the permit was issued after November 8, 1984 (see 40 CFR 270.60).

\section{Administrative Requirements}

Off-site CERCLA actions must comply with the following administrative requirements of the UIC Program:

- Application requirements. All existing and new underground injection wells must apply for a permit unless an existing well is authorized by rule for the life of the well;

- Inventory and Other Information Requirements. Existing underground injection wells that are authorized by rule are required to submit inventory information to EPA or an approved State. Other information may be required to determine whether injection will endanger an underground source of drinking water, and

- Reporting Requirements. Owners and operators of Class I wells are required to maintain records and report quarterly on the characteristics of injection fluids and ground-water monitoring wells and various operating parameters (e.g., pressure, flow rate, etc.). 
NOTE: Off-site CERCLA actions must also comply with , CERCLA requirements for off-site transfers of waste. (OSWER Directive 9834.11, November 1987; 53 FR 48218 , November 29,1988 ).

\section{SOLE SOURCE AQUIFER (SSA) PROGRAM}

The SDWA permits EPA to designate as "sole source aquifers" any aquifer that is the sole source or principal drinking-water source for an area and which, if contaminated, would present a significant hazard to human health. Under the SSA program, Federal financial assistance (from any Federal Agency) may not be committed for any project that may contaminate a sole source aquifer so as to create a significant public health hazard. Generally, CERCLA activities would not in and of themselves increase pre-existing contamination of sole source aquifers. Therefore, it is unlikely that CERCLA activities would be subject to restrictions on Federal fin- ancial assistance. Nonetheless, a review of any potential problems associated with sole source aquifers should be part of the RI/FS process.

\section{WELLHEAD PROTECTION PROGRAM}

The 1986 amendments to the SDWA direct States to develop and implement programs to protect wells and recharge areas that supply public drinking-water systems from contaminants that flow into the well from the surface and subsurface. Because the Wellhead Protection program is designed to be run by the States, the program will not involve Federal ARAR provisions. Nonetheless, State Wellhead Protection programs may impose requirements that may be ARARs for CERCLA response actions. RPMs should be aware of State Wellhead Protection program requirements and should coordinate with the appropriate Regional drinking-water program personnel assigned to the Wellhead Protection program.

\section{RESOLUTION OF POTENTIALLY CONFLICTING ARARS}

For relevant and appropriate requirements, the very availability of a certain requirement often suggests that other requirements, which are less well suited to the circumstances, are not relevant and appropriate. Several conceivable conflicts among potential relevant and appropriate requirements concerning surface water may be resolved as follows:

- Where surface water serves as actual or potential drinking-water source and there are no impacts to aquatic organisms, the following requirements should

- be attained where relevant and appropriate:

(1) State WQS that are designated for drinkingwater use, and are more stringent than Federal standards, or specific to the uses of that water body; or, if none

(2) Non-zero MCLGs; or, if none
(3) MCLs; or, if none

(4) Federal WQC adjusted for drinking-water use.

- For non-drinking surface water and there are no impacts to aquatic organisms, attain where relevant and appropriate, the stricter of:
(1) State WQS; or
(2) Technology Based Limitations.

- For non-drinking surface water and there are impacts to aquatic organisms, attain, where relevant and appropriate:

(1) State WQS; or, if none

(2) Federal WQC. 


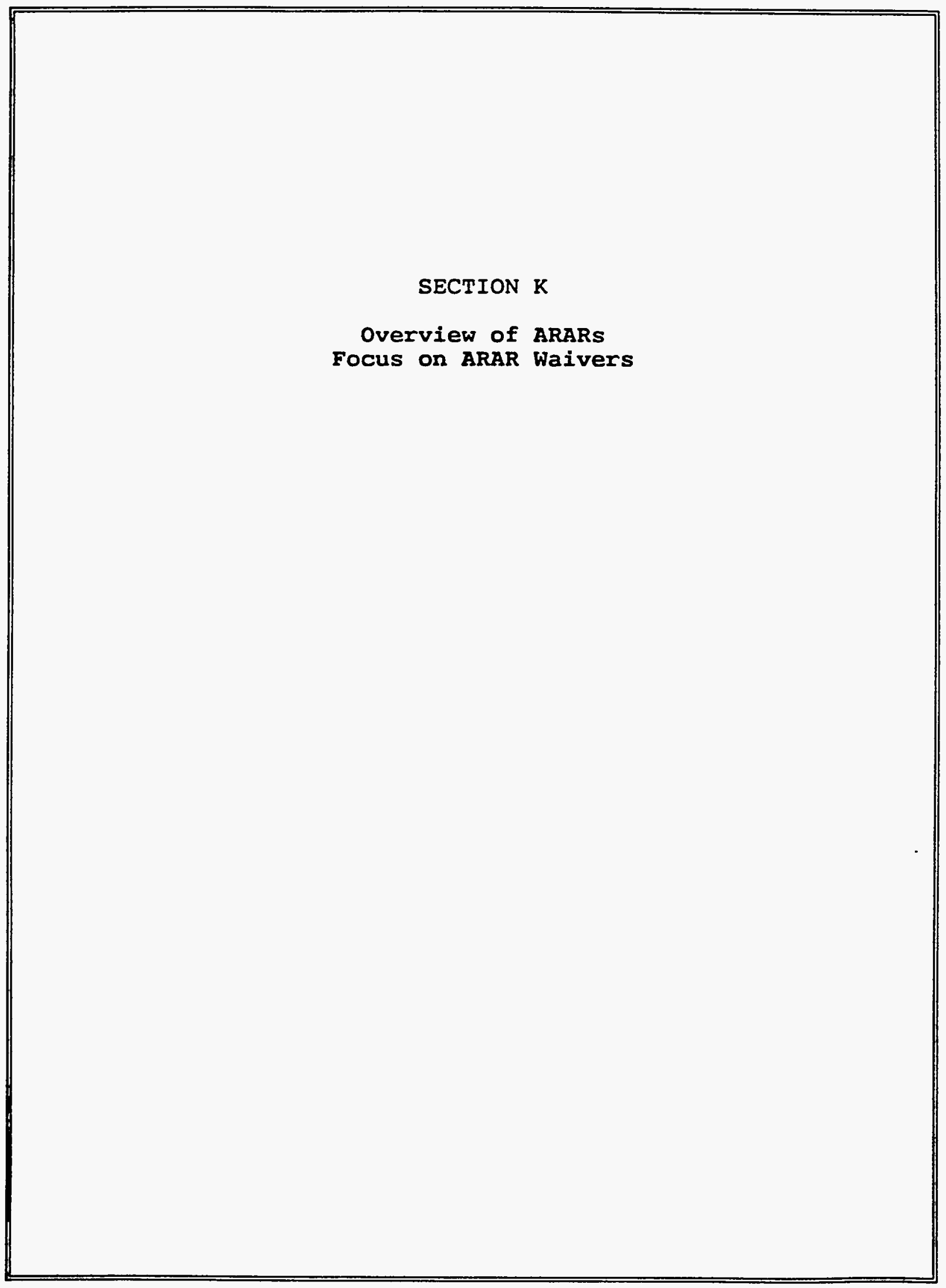




\section{United States \\ Environmental Protection

The Superfund Amendments and Reauthorization Act of 1986 (SARA) adopts and expands a provision in the 1985 National Contingency Plan (NCP) that remedial actions must at least attain applicable or relevant and appropriate requirements (ARARs). Section 121(d) of CERCLA, as amended by SARA, requires attainment of Federal ARARs and of State ARARs in State environmental or facility siting laws when such requirements are promulgated, are more stringent than Federal laws, and are identified by the State in a timely manner.

To implement the ARARs provision, EPA has developed guidance, CERCLA Compliance With Other Laws Manual: Parts I and II (OSWER Directives 9234.1-01 and 9234.1-02). EPA is preparing a series of short fact sheets that summarize these guidance documents. This fact sheet summarizes Chapter 1 of Part I, which provides an overview of ARARs. The material covered here is based on policies in the proposed revisions to the NCP. The final NCP may adopt policies different from those covered here and should, when promulgated, be considered the authoritative source.

\section{OVERVIEW OF ARARS}

\section{A. Statutory Provisions}

CERCLA section 121(d)(2) states that for wastes left on-site, remedial actions must comply with Federal and State environmental laws that are legally applicable or are relevant and appropriate under the circumstances of the release. This section, in effect, codified and expanded on the $1985 \mathrm{NCP}$, which required compliance with Federal applicable or relevant and appropriate requirements (ARARs), a provision adopted to make use of other programs' or agencies' standards.

In addition, CERCLA requires Superfund remedial actions to comply with State environmental or facility siting laws provided that the State requirements: (1) are promulgated; (2) are more stringent than Federal laws; and (3) are identified by the State in a timely manner. CERCLA section 121(d) also mentions two criteria specifically -- Maximum Contaminant Level Goals (MCLGs) developed under the Safe Drinking Water Act (SDWA), and Water Quality Criteria (WQC) developed under the Clean Water Act (CWA) -- and requires that they be attained when they are relevant and appropriate (compliance with these criteria is discussed in a separate fact sheet). CERCLA also specifies six circumstances in which ARARs can be waived. The ARAR waivers are discussed in Part II of this fact sheet.

\section{B. Compliance with ARARs for Removal Actions}

Although CERCLA requires compliance with ARARs for remedial actions only, the current NCP requires that removal actions also comply with Federal ARARs, to the extent practicable. Furthermore, EPA policy under the proposed NCP requires that removal actions comply with both State and Federal ARARs to the extent practicable. Until this policy is promulgated by regulation, however, compliance with State ARARs during removal actions must be justified based upon protectiveness.

Factors used in determining whether removal compliance with ARARs is practicable include: (1) the urgency of the situation; and (2) the scope of the removal action to be conducted, which includes consideration of the statutory limits for removal actions. An example of a situation where compliance with ARARs is not practicable for a removal action would be a site where emergency conditions call for a rapid response, thereby preventing the on-scene coordinator from identifying and attaining ARARs. An ARAR that is beyond the scope of a removal to remediate top-level soil contamination due to leaking drums might be one that applies to lower-level soil remediation. Of course, such a standard may still be an ARAR for any remedial action that is subsequently taken at the site. 


\section{Definitions of ARARs and TBCs}

In the proposed revisions to the NCP (53 FR 51394), EPA clarified the definitions of "applicable" and "relevant and appropriaten ${ }^{n}$ requirements (see Highlight 1 ).

\section{Highlight 1: DEFINITION OF "APPLICABLE" AND "RELEVANT AND APPROPRIATE" REQUIREMENTS}

Applicable requirements are defined as "cleanup standards, standards of control, and other substantive environmental protection requirements, criteria, or limitations promulgated under Federal or State law that specifically address a hazardous substance, pollutant, contaminant, temedial action, location, or other circumstance at a CERCLA site."

Relevant and appropriate requirements are defined as "substantive environmental protection requirements ... promulgated under Federal or State law that, while not "applicable", ... address problems or situations sufficiently similar to those encountered at the CERCLA site that their use is well suited to the particular site."

\section{Applicable Requirements}

An applicable requirement directly and fully addresses the situation at the site. In other words, an applicable requirement is a substantive requirement that a private party would be subject to if it were undertaking the action independently from any CERCLA authority. For a requirement to be applicable, all jurisdictional prerequisites of the requirement must be met, including: (1) the party subject to the law; (2) the substances or activities that fall under the authority of the law; (3) the time period during which the law is in effect; and (4) the types of activities the statute or regulation requires, limits, or prohibits.

\section{Relevant and Appropriate Requirements}

While a determination of applicability is primarily a legal one, a determination of whether a requirement is relevant and appropriate is site-specific and is based on best professional judgment, taking into account the circumstances of the release or threatened release. This determination should be made in conjunction with pertinent national policies.

There is more flexibility and discretion in making relevant and appropriate determinations than in determining the applicability of a requirement. Only those requirements that are both relevant and appropriate are ARARs. A requirement may be relevant, but not appropriate, because of the site circumstances. Such a requirement would not be an ARAR for the sit Moreover, it is possible for only a portion of a requirement to be considered relevant and appropriate, while other parts may not. However, once a requirement (or part of a requirement) is found to be relevant and appropriate, it must be complied with to the same degree as if it were applicable.

In determining whether a requirement is both relevant and appropriate to the circumstances of the release, the following comparisons should be made:

- The purpose of the requirement and the purpose of the CERCLA action;

- The medium regulated or affected by the requirement and the medium contaminated or affected at the CERCLA site;

- The substances regulated by the requirement and the substances found at the CERCLA site;

- The actions or activities regulated by the requirement and the remedial action contemplated at the CERCLA site;

- Any variances, waivers, or exemptions of th requirement and their availability for use given th. circumstances at the CERCLA site;

- The type of place regulated and the type of place affected by the CERCLA site or CERCLA action;

- The type and size of the structure or facility regulated and the type and size of the structure or facility affected by the release or contemplated by the CERCLA action; and

- Any consideration of the use or potential use of affected resources in the requirement and the use or potential use of the affected resource at the CERCLA site.

A similarity to any one factor is not necessarily sufficient to determine that a requirement is relevant and appropriate. Nor does a requirement have to be similar to the site situation with respect to each factor in order for it to be relevant and appropriate.

\section{TBCs}

By definition, ARARs are promulgated, or legally enforceable Federal and State requirements. (Because CERCLA identifies them as potentially relevant and appropriate, MCLGs and WQC are considered potentia ARARs, even though they are not otherwise enforceable standards.) EPA has also developed another category of requirements, known as "to be considered" (TBCs), that includes nonpromulgated criteria, advisories, guidance, 
and proposed standards issued by Federal or State governments. TBCs are not potential ARARs because they are neither promulgated nor enforceable. It may be necessary to consult TBCs to interpret ARARs, or to determine preliminary remediation goals when ARARs do not exist for particular contaminants. However, identification and compliance with TBCs is not mandatory in the same way that it is for ARARs.

\section{Types of ARARs}

EPA has divided ARARs into three categories to facilitate their identification:

- Chemical-specific ARARs are usually health- or riskbased numerical values or methodologies used to determine acceptable concentrations of chemicals that may be found in or discharged to the environment, e.g., MCLs that establish safe levels in drinking water.

- Location-specific ARARs restrict actions or contaminant concentrations in certain environmentally sensitive areas. Examples of areas regulated under various Federal laws include floodplains, wetlands, and locations where endangered species or historically significant cultural resources are present.

- Action-specific ARARs are usually technology- or activity-based requirements or limitations on actions or conditions involving specific substances.

Chemical- and location-specific ARARs are identified early in the process, generally during the site investigation, while action-specific ARARs are usually identified during the Feasibility Study (FS) in the detailed analysis of alternatives.

\section{E. Compliance with ARARs for On-site and Off-site Actions}

The ARARs provision in CERCLA addresses only on-site actions (see Highlight 2 for definition of on-site). In addition, section 121(e) exempts on-site actions from having to obtain Federal, State, and local permits. Consequently, the requirements under CERCLA for compliance with other laws differ for on-site and off-site actions, as follows:

- On-site actions must comply with applicable and relevant and appropriate requirements, but need comply only with the substantive parts of those requirements.

- Off-site actions must comply only with requirements that are legally applicable, but must comply with both substantive and administrative parts of those requirements.
(See Highlight 3 for definitions of "substantive" and "administrative".) Compliance with "relevant and appropriate" requirements is not required for off-site actions.

\section{Highlight 2: DEFINITION OF "ON-SITE"}

"On-site" is defined in the proposed revisions to the NCP as the rareal extent of contamination and all suitable areas in very close proximity to the contamination necessary for implementation of the response action." See 53.FR 51477 . (December 21, 1988). "Areal extent of contamination". refers to both surface area, ground water beneath the site, and air above the site. Examples of on-site contamination and treatment nnits or staging areas separate from (but in "very close proximity to") the contamination include:

- A disposal site for treated wastes in a new landfill outside, but in close proximity to, a contaminated wetland;

- A point-source discharge into a river running through a site. The discharge point would be considered on-site, even if the discharge effluent ultimately runs off-site. The action wonld have to meet discharge limitations and monitoring requirements, but would not require an NPDES permit; and

- A pump-and-treat system located in the contamination plume several miles downgradient of the source. The ground-water treatment system is considered on-site.

Highlight 3: DEFINITIONS OF SUBSTANTTVE AND ADMINISTRATIYE REOUIREMENTS A s Substantive requirements are those Jequirements that pertait drecty to actoons or condifions in the environment Examples include quantitatiye health or risk-based standards for certain hazardo us sutostancos o e MCLs for drinking water) and technologybased standards (e g, RCRA minimum technology fognirements for doublo aners and geachate collection systems)

Administrative requirements are those mechanisms that facilitate the imptementation of the substantive requirements of a statute or regulation (e,g, requirements related to the approval of of consultation with auministrative bodies, documentation permit issuances, reporting; recordkeeping, and enforcement). 


\section{F. ARARs Documentation}

ARARs considered for each alternative in the detailed analysis of alternatives should be documented in detail in the Remedial Investigation/Feasibility Study (RI/FS). The Proposed Plan and the ROD should summarize how the components of an alternative will comply with major ARARs, and should describe why the requirement is applicable or relevant and appropriate. The ROD should document ARARs as follows: (1) major ARARs should be discussed in the Description of Alternatives; (2) ARAR compliance should be summarized in the Summary of the Comparative Analysis; and (3) all ARARs selected for the remedy should be listed and briefly described in the Statutory Determinations section.

When an alternative is chosen that does not attain an ARAR, the basis for waiving the requirement must be fully documented and explained. TBCs referred to in the ROD should be listed and described briefly, as well as the reasons for their use. Generally, there is no need to document why a requirement is not an ARAR, although documentation should be provided for both ARARs and TBCs when the determination has been difficult or controversial. (See Guidance on Preparing Superfund Documents, [ROD Guidance] EPA-540/G-89/007, July 1989, and Guidance for Conducting RI/FSs Under CERCLA, EPA 540/G-89/004, October 1988, for further information.)
G. Policy on Newly Promulgated Requiremen "Freezing" ARARs at the ROD

If a requirement that would be applicable or relevant and appropriate to the remedial action is promulgated after the Record of Decision (ROD) is signed and the ARARs for the selected remedy have already been established, the remedy will be evaluated in light of the new requirement to ensure that the remedy is still protective.

To the extent that the remedy remains protective in light of any new information reflected in the requirement, the original ARARs remain "frozen" at the ROD and nothing more needs to be done. However, if it is determined that the new requirement must be met in order for the remedy to be protective, the remedy must be modified to attain the requirement through an Explanation of Significant Differences (ESD) or ROD amendment. For example, a new requirement for a chemical at a site may indicate, through new scientific information on which it was based, that the cleanup level selected for the chemical corresponds to a cancer risk of $10^{-2}$ rather than $10^{5}$, as originally thought. The original remedy would have to be reevaluated in terms of the new requirement because it may no longer be protective.

\section{FOCUS ON ARAR WAIVERS}

CERCLA section 121(d) provides that, under certain circumstances, an ARAR may be waived. The six statutory waivers are provided in Highlight Box 4 and are discussed more fully below. These waivers may not be used for ofi-site actions.

\section{Highlight 4: STATUTORY ARAR WATYERS}

The six ARAR waivers provided by CERCLA aze:

1. Interim Measures Waryer,

2. Equivalent Standard of Performance Waiver;

3. Greater Risk to Health and the Enviromment Waiver;

4. Technical Impracticability Waiver;

5. Inconsistent Application of State Standard Waiver; and

6. Fund-Balancing Waiver.
The Interim Measure waiver may be used when an interim measure that does not attain all ARARs is expected to be followed by a complete measure that will attain all ARARs (see Highlight Box 5 for an example). The interim measure should not cause additional migration of contaminants, complicate the site response, or present an immediate threat to public health or the environment, and must not interfere with or delay the

\section{Highilght 5: EXAMPLE OF INTERIM} MLEASURES WATVER

At a mining site, interim measures were used to address arainage of contaminated water from a - mine The action involved passive treatment of mine tunnel discharges through construction of an artificial wetlane, which rould reduce contamination from the mine tunnel to the level of contamination present apstream: Since the discharge exceded State anbient water quality standards for the stream, the standards were waived until the final remedy was implemented, which would aldress in-stream contamination.... 
final remedy. It should be noted, however, that if a requirement relates to some portion of the long-range site cleanup that is outside the scope of the immediate remedial action, it is not an ARAR for this action and a waiver is unnecessary.

The Equivalent Standard of Performance waiver may be used in situations where an ARAR stipulates use of a particular design or operating standard, but equivalent or better remedial results could be achieved using an alternative design or method of operation. In invoking this waiver, the alternative should be equal to or greater than the ARAR in terms of: (1) the degree of protection afforded; (2) the level of performance achieved; and (3) the potential to be protective in the future. The time required to achieve beneficial results using the alternative should be considered; however, the duration of the alternative should be balanced against other beneficial factors that may ensue from using the alternative. A technology-based requirement must be evaluated from a technology performance perspective. not from a risk perspective.

The Greater Risk to Health and the Environment waiver is available for situations where compliance with an ARAR will cause greater risk to human health and the environment than noncompliance. The more significant the risks, the longer they are in duration, and the more irreversible the harm from compliance with an ARAR, the more appropriate the use of this waiver (see Highlight 6 for an example).

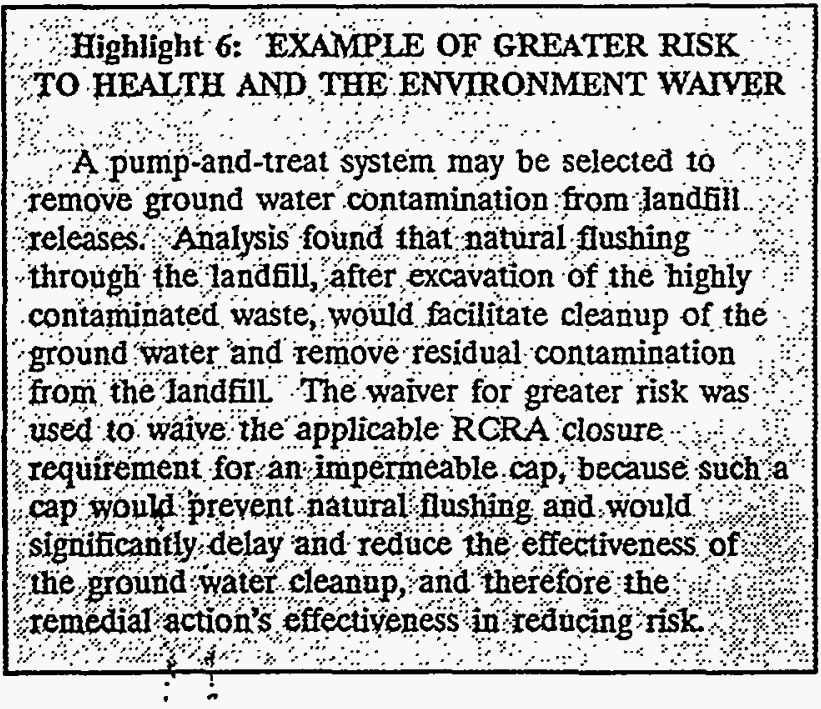

The Technical Impracticability waiver may be used when compliance with an ARAR is technically impracticable from an engineering perspective. The waiver can be used if either of two criteria are met: (1) engineering feasibility, in which current engineering methods necessary to construct and maintain an alternative that will meet the ARAR cannot reasonably be implemented; and (2) reliability, in which the potential for the alternative to continue to be protective into the future is low, either because the continued reliability of technical and institutional controls is doubtful, or because of inordinate maintenance costs. Use of the waiver may consider cost, although cost should not be the major factor (see Highlight 7 for an example).

\section{Highlight 7: EXAMPLE OF TECHNICAL IMPRACTICABHITY WATVER}

Ground water located in bedrock fractures and deep bedrock contained highly contaminated pockets of liquid waste along the fractures. MCLs were waived because their attainment was technically impracticable for several reasons, including: (1) difficulty in predicting the extent and location of fractures; (2) the inability to locate and extract all pockets of liquijd waste; (3) excessive time frames for cleanup; and (4) the irregular .nature of the fractures that made effective placement of extraction wells difficult.

The Inconsistent Application of State Standard waiver may be invoked when evidence exists that demonstrates that a State standard has not been or will not be consistently applied to other remedial sites within the State, including both NPL and non-NPL sites. A waiver may be used, for example, for a State.standard that was promulgated but never applied, or for a standard that has been variably applied or enforced. A State standard is presumed to have been consistently applied unless there is evidence to the contrary.

The Fund-Balancing waiver may be invoked when meeting an ARAR would entail such cost in relation to the added degree of protection or reduction of risk afforded by that standard that remedial actions at other sites would be jeopardized. This waiver should be considered when the cost of attaining an ARAR is $20 \%$ of the annual remedial action budget or $\$ 100$ million, whichever is greater (see Highlight 8 for an example).

\begin{tabular}{|c|}
\hline 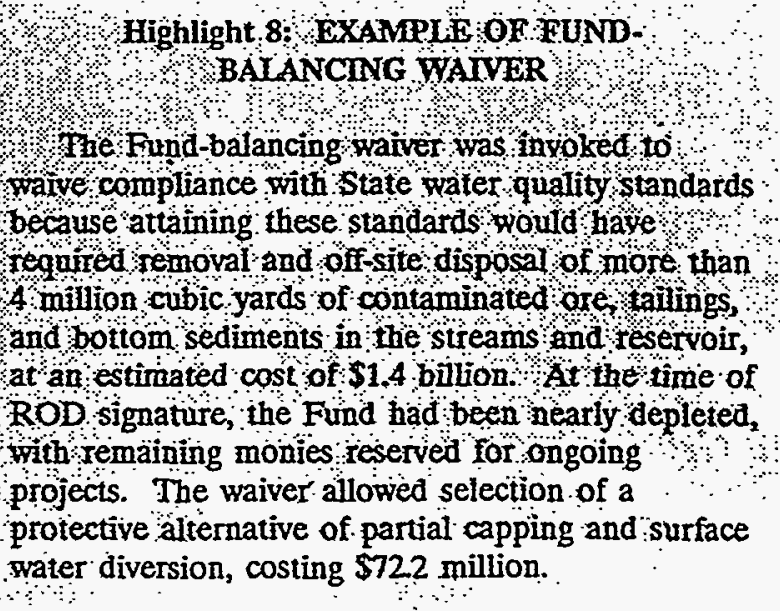 \\
\hline
\end{tabular}




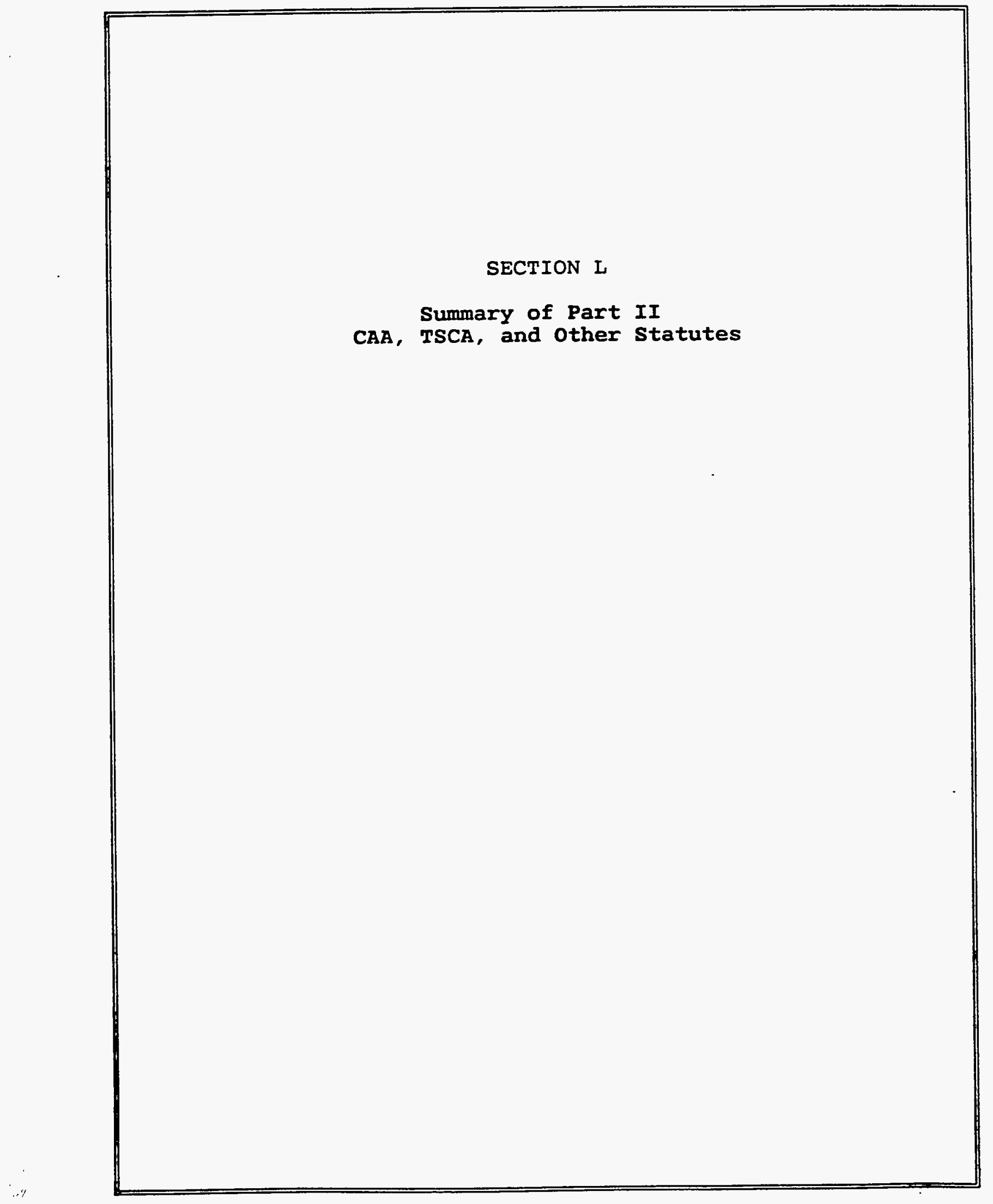




\section{United States

Section 121(d) of CERCLA, as amended by the 1986 Superfund Amendments and Reauthorization Act (SARA), requires that remedial actions must at least attain Federal and more stringent State applicable and relevant and appropriate requirements (ARARs) upon completion of the remedial action. The 1990 National Contingency Plan (NCP) requires compliance with ARARs during remedial actions as well as at completion, and compels attainment of ARARs during removal actions whenever practicable. See NCP, 55 Fed. Reg. 8666, 8843 (March 8, 1990) (to be codified at 40 CFR section 300.414(i)), and 55 Fed. Reg. 8666, 8852 (March 8, 1990) (to be codified at 40 CFR 300.435(b)(2)).

To implement the ARARs provision, EPA has developed guidance, CERCLA Compliance With Other Laws Manual: Parts I and II (Publications 9234.1-01 and 9234.1-02). EPA is preparing a series of shor fact sheets that summarize these guidance documents. This Fact Sheet focuses on CERCLA compliance with the Clean Air Act, the Toxic Substances Control Act, and the Federal Insecticide, Fungicide, and Rodenticide Act (Chapters 2 and 3 of Part II). In addition, it discusses other statutes that set standards for radioactive wastes, mining wastes, and other resource protection statutes that are potential ARARs for CERCLA actions.

\section{STANDARDS FOR AIR}

\section{A. CLEAN AIR ACT (CAA)}

The objective of the CAA is to protect and enhance the quality of the nation's air resources. The CAA achieves this objective by regulating emissions into the air through National Ambient Air Quality Standards (NAAQS), National Emission Standards for Hazardous Air Pollutants (NESHAPs), and New Source Performance Standards (NSPS). These potential ARARs may apply to both stationary and mobile sources of emissions, and they may be implemented through combined Federal, State, and local programs. See Highlight 1 for CERCLA activities that may trigger CAA ARARs.

\section{National Ambient Air Quality Standards (NAAQS)}

Under CAA section 109, EPA promulgates NAAQS. NAAQS are national limitations on ambient concentrations intended to protect health and welfare. There are primary and some secondary NAAQS for six pollutants. (See 40 CFR Part 50.) These pollutants (called "criteria pollutants") are: (1) carbon monoxide; (2) lead; (3) nitrogen dioxide; (4) particulate matter equal to or less than 10 microns particle size $\left(\mathrm{PM}_{10}\right)$; (5) ozone, which results from the emissions of volatile organic compounds (VOCs); and (6) sulfur oxides. Primary standards are set at health-based levels, while secondary standards are designed to protect public welfare and wildlife.

\begin{tabular}{|c|}
\hline 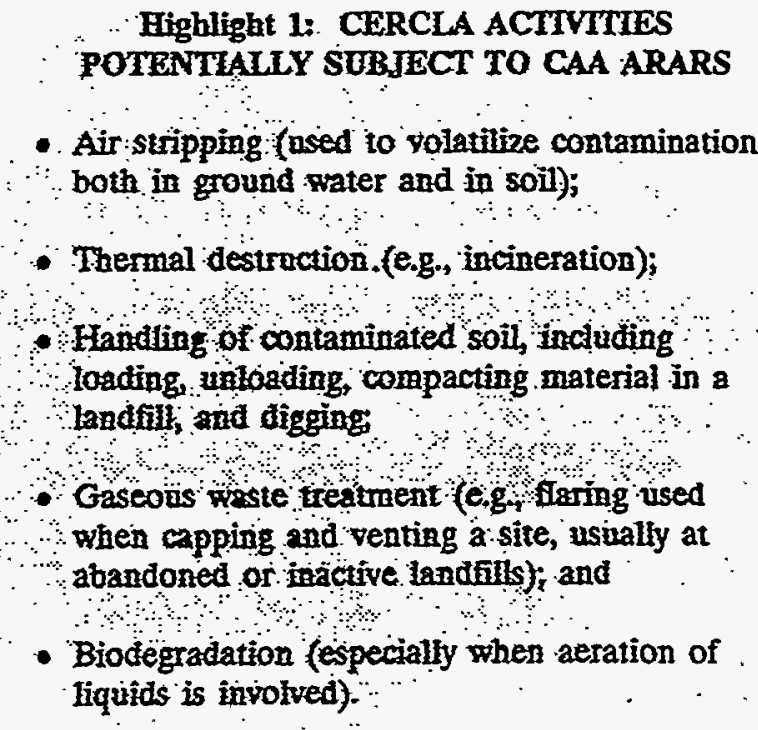 \\
\hline
\end{tabular}


NA2 - a. nc: applicable to source-specific emissions limitations, nor enforceable in and of themselves. States translate them into source-specific emission limitations through State Implementation Plans (SIPs). The CAA requires each State to adopt and submit to EPA for approval a SIP for implementing and enforcing NAAQS. Upon EPA approval, the SIP becomes both Federally enforceable and a potential Federal ARAR at a site. The SIP may contain State, regional, or local air program requirements, or the State may adopt more stringent standards than those found in the SIP. Both State requirements approved through the SIP process and more stringent State standards issued under State law are potential ARARs for Superfund sites.

In addition to requirements established in SIPs for implementing NAAQS, there are regulatory requirements for "major sources" of emissions. The requirements vary depending upon whether the area in which the source is located is an attainment or a non-attainment area. Attainment areas are those regions of the country that are designated as being in compliance with the NAAQS for criteria pollutants (see 40 CFR Part 81). Nonattainment areas are those parts of the country where compliance has not been attained for one or several criteria pollutants. Therefore, a certain area may be designated as an attainment area for one, and a nonattainment area for another, of the criteria pollutants. RPMs should contact EPA Regional Air Branch Chiefs or their Air/Superfund Coordinators for additional questions concerning attainment and non-attainment areas.

In general, emissions from CERCLA activities are not expected to qualify as "major;" therefore, these requirements are not likely to be applicable to CERCLA response actions. Highlight 2 summarizes these requirements for major sources in attainment and nonattainment areas.

For a site where a ground-water pump-and-treat technique or soil vapor extraction is used together with air strippers in an ozone non-attainment area, the June 15, 1989 memorandum entitled, "Control of Air Emissions from Superfund Air Strippers at Superfund Groundwater Sites" (OSWER Directive 9355.0-28), is an important tobe-considered (TBC). The guidance indicates that sources that need controls are those with actual emissions rates in excess of $3 \mathrm{lbs} / \mathrm{hr}$, or $15 \mathrm{lbs} /$ day, or a calculated rate of 10 tons/year (T/yr) of total VOCs.

\section{National Emissions Standards for Hazardous Air Pollutants (NESHAPs)}

Hazardous air pollutants are those pollutants for which no ambient air quality standard exists, but which cause, or contribute to, air pollution that may reasonably be anticipated to result in an increase in mortality or an
Highlight 2: REQUIREMENTS FOR MAJOR SOURCES IN ATTAINMENT AND NON-ATTAINMENT AREAS

Attainment Areas and Areas Defined as Unclassified

- Requirement: Prevention of Significant Deterioration (PSD) regulations, found at 40 CFR Part 52, require that affected sources meet an emission limit that reflects the installation and operation of Best Available Control Technology (BACT). PSD permit regulations also require that the source meet specified air quality deterioration increments.

- Applicable To: New stationary major source of emissions and major modification to existing source in an attainment or unclassified area.

- Definition of Major Source: Either emits 250 or more T/yr of any regulated pollutant, or the site has a facility such as an incinerator or chemical processing plant that emits 100 or more T/yr.

\section{Non-attainment Areas}

- Requirement: Must meet Lowest Achievable Emission Rate (LAER). Additionally, the SIP must contain a growth allowance or the operator of the source must provide an emissions offset.

- Applicable To: Anything that falls within the definition of a major source for non-attainment areas (not source-specific).

- Definition of Major Source: Emissions of 100 or more Thy of the pollutant designated as non-attainment in that area.

increase in serious irreversible illness. The CAA requires EPA to list periodically the hazardous air pollutants it intends to regulate, and to establish emission standards (NESHAPs) for them. NESHAPs are listed at $40 \mathrm{CFR}$ Part 61.

NESHAPs have been promulgated for emissions $r$ particular air pollutants from specific sources. NESHAI are not generally applicable to Superfund response actions because CERCLA sites do not usually contain one of the specific source categories regulated. More- 
over, NESHAPs are generally not relevant and appropriate because the standards are intended for the specific sources regulated and their use will generally not be well-suited for all sources of that pollutant. As a possible exception, the NESHAPs for asbestos and radionuclides may be ARARs for a CERCLA site (see Highlight 3).

\section{New Source Performance Standards (NSPS)}

The CAA requires EPA to promulgate NSPS for new stationary sources that emit particular pollutants that cause or significantly contribute to air pollution. Since NSPS are source-specific requirements, they are not applicable to Superfund response actions unless they include a "new sourcen subject to NSPS, such as a municipal waste combustor. If the response action does not include a source subject to NSPS, NSPS may be relevant and appropriate if the pollutant emitted and the technology employed at the site are sufficiently similar to the pollutant and source category regulated by an NSPS, so that their use is well-suited to site circumstances. For example, if cleanup involvcs incineration at a municipal landfill, the NSPS for particulate emissions from incinerators with a charging rate of $50 \mathrm{~T} /$ day, which are used for burning solid waste containing more than 50 percent municipal-type waste, may be a potential ARAR.

\section{B. RESOURCE CONSERVATION AND RECOVERY ACT (RCRA) AIR EMISSION REGULATIONS}

There are RCRA regulations covering hazardous waste air emissions from incinerators, land disposal facilities, and other treatment, storage, and disposal facilities (TSDFs). The potential ARARs for incinerators consist of standards for destruction and removal efficiency, for products of incomplete combustion, metals, and emissions of hydrogen chloride, and for particulates. Potential ARARs for land disposal facilities are limited to the requirement that particulate matter from such facilities be controlled by covers or other means. Potential ARARs for TSDFs include air emission standards for process vents and equipment leaks, and air emission standards for container storage, tanks, surface impoundments, and waste fixation units (see 40 CFR Parts 264 and 269).

\section{STATE AIR TOXIC PROGRAMS}

Several State air pollution control agencies have adopted programs to regulate "toxic air pollutants." These requirements are likely to be the most significant air emission ARARs at Superfund sites. Different States have regulations for different pollutants and have adopted differing levels of safety. RPMs should coordinate with the appropriate State agency and their own Regional Air/Superfund Coordinator to determine what potential
ARARs (if any) the pertinent State Air Toxic Program contains.

Highlight 3: POTENTIAL NESHAP ARARS

\section{POTENTIAL ASBESTOS NESHAP ARARS}

- 40 CFR section 61.147 establishes procedures for asbestos emission control during demolition of buildings or equipment containing friable asbestos material. This regulation may be an ARAR for a response action that includes demolishing a building containing asbestos.

- 40 CFR section 61.153 sets standards for inactive waste disposal sites from asbestos mills and manufacturing and fabricating operations; 40 CFR section 61.156 establishes standards for active waste disposal sites; and $40 \mathrm{CFR}$ section 61.152 establishes standards for disposal of asbestos containing waste from demolition and renovation operations. These standards may be ARARs for response actions involving asbestos disposal.

\section{POTENTIAL RADIONUCLIDE NESHAP ARARS}

- 40 CFR Part 61, Subparts H and I are applicable to airborne emissions of radionuclides (excluding radon-220 and 222 for Subpart H and radon-222 for Subpart 1) from incinerators, land disposal facilities, and other TSDFs for radioactive materials, during the cleanup of sites at Department of Energy (DOE) facilities, Nuclear Regulatory Commission-licensed facilities, and non-DOE Federal facilities, such as Department of Defense facifities.

- 40. CFR Part 61, Stuppart T applies to radon222 emissions from the disposal of uranium mill tailings Subpart W applies to uranium mill tailings piles during operation; Subpart $R$ applies to radon-222 emissions from phosphogrpsum stacks (piles) after disposal :and Subpart $Q$ appies to radon-222 emissions from storage and disposal facilities for rädiumcontaining material that are owned or operated by DOE (seo NCP, S4 Fed Reg: 51654 (December 15, 1989) for Subparts $T, Q$, and R) These subparis may be ARARs if the response action occurs at an underground aranium mine or at a uranium mill site. They may be potential ARARs for other CERCLA. sites (especially mining sites). 


\section{STANDARDS FOR TOXICS AND PESTICIDES}

\section{A. TOXIC SUBSTANCES CONTROL ACT (TSCA)}

TSCA authorizes EPA to establish testing, premanufacture notification, control, and recordkeeping regulations pertaining to toxic chemical substances. Those requirements that regulate control of polychlorinated biphenyls (PCBs), fully halogenated chlorofluoroalkanes, and asbestos are potential ARARs for CERCLA response actions. In addition, EPA generates risk numbers for chemicals to be studied under TSCA. These risk numbers for particular chemicals may constitute guidelines that are TBC, and may be consulted when developing a protective remedy.

\section{PCB Disposal Requirements}

PCB disposal requirements under TSCA will be applicable if disposal of material contaminated with PCBs at concentrations of $50 \mathrm{ppm}$ or greater occurred after February 17, 1978. (These requirements may be relevant and appropriate if disposal occurred before that date.) TSCA requirements for disposal of PCB-contaminated wastes vary according to the physical state of the PCBs (liquid, non-liquid, or articles), and PCB concentration. See the CERCLA Compliance with Other Laws Manual, Part II, Chapter 3 (pp. 3-2 through 3-5) for a complete list of potential TSCA ARARs for PCBs. The Office of Emergency and Remedial Response is finalizing a Guidance on Remedial Actions for Superfund Sites with PCB Contamination (OSWER Directive 9355.4-01) that discusses the circumstances under which the $P C B$ antidilution requirements may apply at CERCLA sites.

\section{PCB Storage Requirements}

The substantive portions of the PCB storage requirements found at $40 \mathrm{CFR}$ section 761.65 may be ARARs for the storage of PCBs prior to disposal. Other potential ARARs include requirements for PCB storage facilities and containers.

\section{PCB Spill Cleanup Policy}

EPA has published a nationwide TSCA PCB spill cleanup policy in $40 \mathrm{CFR}$ Part 61, Subpart G. The action-specific and cleanup guidelines contained within this policy are potential TBCs, especially with respect to the cleanup of PCB-contaminated soils. The spill policy is effective for PCB spills occurring after May 4, 1987.

\section{B. RCRA LAND DISPOSAL RESTRICTIONS (LDRS) FOR PCBs}

The land disposal of liquid RCRA hazardous wastes that contain PCBs at concentrations equal to or greater than $50 \mathrm{ppm}$, are regulated by RCRA under the California List Wastes LDRs, promulgated on July 8 , 1987 (see Highlight 4). RCRA LDRs for PCBs may be ARARs when the response action involves excavating, dredging, or other measures that move PCB-contaminated materials into a land-based unit.

\section{Highlight 4: RCRA LDR REQUTREMENTS FOR PCBS}

- Liquid RCRA hazardous wastes containing PCBs at concentrations between 50 and 499 ppm must be incinerated (or treated by an equivalent method) in a facility that meets the requirements of 40 CFR section 761.70 , or burned in a high efficiency boiler meeting the requirements of $40 \mathrm{CFR}$ section 761.60 . See 40 CFR section $268.42(a)(1)$.

- Liquid RCRA hazardous wastes containing PCBs at concentrations equal to or greater than $500 \mathrm{ppm}$ must be incinerated consistent with the technical requirements of $40 \mathrm{CFR}$ section 761.70 or be treated by an equivalent method. See 40 CFR section 268.42(a)(1).

- Nonliquid and liquid RCRA hazardous wastes containing PCBs and halogenated organic componnds (HOCs) must be incinerated consistent with the requirements of Part 264, Subpart $O$, or Part 265, Subpart $O$, if the total concentration of HOCs is equal to or greater than 1,000 mg/kg. In the proposed third thirds rule under RCRA, EPA is proposing to revoke the California List provision allowing burning of HOCs in furnaces and boilers (see 54 Fed. Reg. 48499 (November 22, 1989)). This rule will not affect the PCB regulations mentioned above.

\section{c. FEDERAL INSECTICIDE, FUNGICIDE, AND RODENTICIDE ACT (FIFRA)}

FIFRA authorizes EPA to regulate the sale, distribution, and use of all pesticide products in the United States through product licensing or registration. Under FIFRA, use of a product in a manner inconsistent with its labeling is a violation of the Act. However, compliance with FIFRA by following labeling directions may not be required at a Superfund site since the pesticide may be a RCRA waste at that point. 
TBCs under FIFRA include nonbinding "procedures not recommended" for disposal of pesticides (see 40 CFR section 165.7) and nonbinding "recommended procedures" for disposal of pesticides (see 40 CFR section 165.8). In addition to disposal TBCs, there are tolerance levels for pesticides and pesticide residuals in or on raw agricultural commodities. These tolerance levels are potential ARARs where sites have agricultural commodities or wildlife for consumption.
Discharges of pesticides to surface waters through a point source are subject to effluent limitations as toxic pollutants under the Clean Water Act (CWA). The CWA requirements are, therefore, potential ARARs for such discharges. In addition, discarded or offspecification pesticides may be regulated under RCRA Subtitle $C$ as -listed or characteristic hazardous wastes. Thus, RCRA Subtitle $C$ requirements are potential ARARs for such pesticides.

\section{STANDARDS FOR RADIOACTIVE WASTES}

There are few standards applicable to the cleanup of radioactively contaminated sites and buildings, except for standards for mill tailings under the Uranium Mill Tailings Radiation Control Act and EPA's standards (when promulgated) for residual radioactivity for cleanup of a site where radionuclides have been used. Other standards for radioactive waste may be relevant and appropriate when determined to be well-suited for cleanup of a specific site. When reviewing potential ARARs, it is important to determine under which Agency's regulatory jurisdiction a site falls, in order to help determine applicability.

\section{A. POTENTIAL EPA ARARS FOR RADIOACTIVE WASTE}

Under the CAA EPA has promulgated radionuclide NESHAPs for five different source categories. Subparts $\mathrm{H}$ and $\mathrm{I}$, which address DOE, Nuclear Regulatory Commission (NRC)-licensed, and non-DOE Federal facilities, are most likely to be potential ARARs for CERCLA response actions (see 40 CFR Part 61). Under the Safe Drinking Water Act, EPA has promulgated maximum contaminant levels (MCLs) for radionuclides in two forms: (1) radioactivity concentration limits for certain alpha-emitting radionuclides; and (2) an annual dose limit for the ingestion of certain beta/gamma-emitting radionuclides (see 40 CFR Part 141). Since the radionuclides MCLGs equal zero, the MCLs are potential ARARs for Superfund sites. Under the Atomic Energy Act, there are environmental protection standards that set limits on radiation doses received by members of the general public from operations within the uranium fuel cycle of nuclear generators. While these standards are not applicable because they apply to normal operations and planned discharges, they may be relevant and appropriate to releases of radionuclides and radiation during cleanup of radioactively contaminated sites (see 40 CFR Part 190). Under the Uranium Mill Tailings Radiation Control Act, EPA has set standards for mill tailings at two types of

sites: (1) certain inactive uranium processing sites "designated" for remedial action under section 102 of the Uranium Mill Act; and (2) commercial uranium and thorium processing sites licensed by the NRC or States (see 40 CFR Part 192). EPA has also established surface-water discharge standards for radionuclides. These standards are applicable to discharges from certain kinds of mines and mills; they may be relevant and appropriate to response actions involving discharges of radionuclides to surface waters from other types of sites (see 40 CFR Part 440).

\section{B. POTENTIAL NRC ARARS FOR RADIOACTIVE WASTE}

Standards found in $10 \mathrm{CFR}$ Part 20 may be applicable to CERCLA actions at NRC-licensed facilities; they may be relevant and appropriate to CERCLA actions at radioactively contaminated sites not licensed by the NRC. These standards establish permissible levels of radiation in unrestricted areas, concentration limits for discharges to unrestricted areas, and waste disposal requirements.

Standards found in 10 CFR Part 61 establish criteria applicable to existing licensed low-level waste disposal sites. These criteria are not applicable to previously closed sites such as existing CERCLA sites. However, the technical requirements may be relevant and appropriate to CERCLA sites with low-level radioactive waste, if the waste will be permanently left on site.

Standards found in $10 \mathrm{CFR}$ Parts 30,40 , and 70 contain licensing requirements for the possession and use of byproduct, source, and special nuclear material, respectively. Any substantive requirements found within these standards may be applicable to response actions at sites licensed under these NRC regulations. They may be relevant and appropriate to other, non-licensed sites that contain radioactive contamination.

\section{POTENTIAL DOE ARARS FOR RADIOACTIVE WASTE}

Most of DOE's operations are exempt from NRC's licensing and regulatory requirements. DOE's requirements for radiation protection and radioactive waste management are found in internal DOE orders. These 
orders have the same force for DOE facilities as does a regulation; however, because they are not promulgated requirements, they are not potential ARARs. The requirements in the orders are applicable only to DOE installations and do not apply to sites outside of DOE's jurisdiction.

Because - DOE's orders typically incorporate requirements promulgated by other Federal agencies, they should be consistent with existing regulations. To the extent that they are more stringent or cover issues not addressed by existing ARARs, they may be TBCs at a site. The most important DOE orders concerning radiation protection and radioactive waste management are DOE 5400.5, "Radiation Protection of the Public and the Environment," and DOE 5820.2A, "Radioactive Waste Management."

\section{STANDARDS FOR MINING WASTES}

Potential ARARs under the Uranium Mill Tailings Radiation Control Act are discussed in the preceding section. Other potential ARARs for mining wastes are found in the Surface Mining Control and Reclamation Act and in the Resource Conservation and Recoverv Act.

\section{A. SURFACE MINING CONTROL AND RECLAMATION ACT (SMCRA)}

Requirements under SMCRA may be applicable to response actions associated with abandoned coal mines (see 30 CFR Part 816). Highlight 5 illustrates when requirements in 30 CFR Part 816 may be relevant and appropriate for response actions at other types of mining sites.

\section{Highlight 5: POTENTIAL MINING WASTE ARARS}

- Where a site contains geologic materials containing sulfides, there may be a release or threat of a release of acid. Such a release could mobilize a related release of acid-soluble metals that are hazardous substances, thus adversely affecting aquatic and other resources. 30 CFR Part 816.4 requirements that boreholes and shafts be sealed to prevent drainage from or into ground water may be relevant and appropriate to such a site.

- Where a site is subject to erosion, it is vulnerable to releases of wastes that are contaminated by heavy metals. Revegetation requirements found in 30 CFR section 816.111 may be relevant and appropriate to protect a cap at a CERCLA mining sitè from erosion and to prevent further releases of arsenic or heavy metals.

\section{B. RCRA STANDARDS}

RCRA section 3001(b) (known as the Bevill Amendment) temporarily prohibited EPA from regulating, as hazardous waste, the solid waste from the extraction and processing of ores and minerals, pending further study and regulation by the Agency. Therefore, Subtitle $C$ requirements were not applicable to mining wastes, nor to soil and debris wastes contaminated with mining wastes (since the contamination does not derive from a RCRA hazardous waste) until EPA made regulatory determination to remove a certain min. waste or waste stream from the Bevill Amendment exclusion. The Bevill Amendment exempted these wastes from Subtitle $C$ requirements even if a waste would otherwise be considered a characteristic hazardous waste. However, the mining wastes may come within the CERCLA definition of hazardous substances, even if they do not contain RCRA hazardous wastes.

EPA has retained 20 mineral processing wastes as "special wastes" (i.e., high volume/low toxicity wastes) under the Bevill Amendment exclusion, which are therefore exempt from Subtitle $C$ requirements until a final regulatory determination is made of their status in January, 1991 (see 54 Fed. Reg. 36592 (September 1, 1989) and 55 Fed. Reg. 2322 (January 23, 1990)). All of the mineral processing wastes that were permanently removed by EPA from the Bevill Amendment exclusion (i.e., any mineral processing waste other than the abovereferenced 20) are subject to RCRA Subtitle $C$ regulation if they are solid wastes and exhibit one or more of the characteristics of hazardous paste, or are otherwise listed as hazardous wastes (see $55 \mathrm{Fed}$. Reg. 2322, 2323 (January 23, 1990.)) EPA has listed the following six smelting wastes as RCRA hazardous wastes: KO64, KO65, KO66, KO88, KO90 and KO91. Therefore RCRA Subtitle $C$ requirements are potential ARARs $f f$ sites containing these wastes (see 53 Fed. Reg. 3541 c (September 13, 1988)). 
Whoine: RCF.2. Sut:!t' C returemenis are reievio: and appropriate for minera! processing wastes that aie within the Bevill Amendment exclusion should be determined on a site-specific basis. However. RCRA Subtitle $C$ requirements are not expected to be relevant and appropriate for most of the exempted wastes because many of the same factors that justified an exemption are used to determine relevance and appropriateness (see NCP, 55 Fed. Reg. 8666, 8763 (March 8, 1990)).

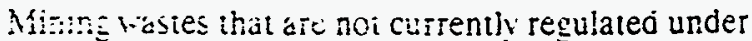
Subtitle $C$ may be subject to Suctitle $D$ requirements. Subtitle $D$ provides performance standards used by States to set standards acceptable for solid waste facilities and management practices. The Agency is developing regulations under Subtitle D specifically for those mining wastes that are not to be regulated as hazardous waste. When promulgated, these regulations may be ARARs for sites where those mining wastes are present.

\section{OTHER RESOURCE PROTECTION STATUTES}

The resource protection laws discussed in this section contain some substantive requirements which may be ARARs, but the majority of their requirements are administrative, such as consultation and reporting requirements. U'nlitic off-site CERCLA response actions. on-site CERCIA investigative and response actions are not required to meet administrative requirements (see NCP. 55 Fed. Reg. S666, \$756 (March \&. 1990)). However, the lead agency should consider consulting with relevant Federal, State. and local agencies to take advantage of their expertise, when an issue arises that is under their jurisdiction (see NCP, 55 Fed. Reg. 8666, 8757 (March S, 1990)). Consultation is most advantageous when initiated early in the process, such as during the preliminary assessment or site investigation.

\section{A. NATIONAL HISTORIC PRESERVATION ACT (NHPA)}

Pursuant to sections 106 and $110(f)$ of NHPA, the lead agency is required to take into account the effects of CERCLA response actions on any historic properties included on, or eligible for inclusion on the National Register of Historic Places. The National Register lists historic properties (known as "cultural resources"), which consist of districts, sites, buildings, structures, and objects that are significant in American history or culture for their architectural, archeological, engineering, or other aspects. For instance, the substantive requirement to avoid adverse effects on cultural resources, found in 36 CFR section $800.5(\mathrm{e})$, is a potential ARAR.

To comply with potential NHPA ARARs, the lead agency should initially determine whether there are any possible historic properties located on or near the site, or within or near the area under study in the remedial investigation. For example, many. CERCLA sites could contain remains of archeological significance, such as American Indian artifacts. If such a possibility seems likely, the lead agency should first contact the Department of the Interior (DOI), which maintains the National Register. Single copies of the National Register are available from: National Register, U.S. Department of the
Interior, Washington, DC 20240. Annual updates of new National Register listings are published in the Federal Register each February or March. The Federal Register will also list properties already determined by the Secretary of Interior to be eligible for the National Register. Finally, information on National Register listings may also be obtained from the State Historic Preservation Officers (SHPOs). who are appointed by their respective governors. .

If the site or any portion of the site has not been determined by the $\mathrm{DOI}$ to be eligible for inclusion on the National Register, the lead agency should make such a determination. The regulations at $36 \mathrm{CFR}$ section 60.4 establish the criteria used to determine whether propertíes qualify for inclusion on the National Register. These criteria are applied to properties through a "cultural resource survey" (CRS). Most of the information needed to complete the CRS will be developed during the RI/FS. When cultural resources are identified, the lead agency evaluates and considers any effects upon cultural resources as part of its review of alternatives during the RI/FS, in order to avoid or minimize adverse effects on these resources. See the CERCLA Compliance with Other Laws Manual, Part II, Chapter 4 (pp. 4-6 through 4-10) for further detailed discussion. Consultation procedures between EPA, the Advisory Council, and SHPOs are being formalized in a Programmatic Memorandum of Agreement (in draft at the time of this printing).

\section{B. ENDANGERED SPECIES ACT (ESA)}

Section 7(a) of the ESA requires Federal agencies to consult with DOI and the National Oceanic and Atmospheric Administration (NOAA), as appropriate, to ensure that their actions are not likely to jeopardize the continued existence of endangered or threatened species, or adversely modify or destroy their critical habitats. Actions that might jeopardize species include direct and indirect effects, as well as the cumulative effects of other actions, whether interdependent, interrelated, or located on another nearby hazardous waste cleanup site. 
Substantive ARARs under the ESA consist of the requirements that the lead agency determine whether a threatened or endangered species, or its critical habitat, will be affected by a proposed response action. This is accomplished through the performance of a biological assessment. If such a determination is made that a threatened species or habitat will be affected by the planned action, the lead agency must avoid the action or take appropriate mitigation measures. If at any point the conclusion is reached that endangered species are not present or will not be affected, no further analysis or action would be required in order to comply with ESA.

To determine whether the project is likely to jeopardize the continue existence of any endangered or threatened species or result in the destruction or adverse modification of a critical habitat, the lead agency should consult with the U.S. Fish and Wildife Service (FWS) for terrestrial and freshwater species and NOAA for marine species. EPA (Office of Solid Waste and Emergency Response), FWS, and NOAA are planning to formalize consultation procedures for both removal actions and on-site remedial actions in a Memorandum of Understanding (in draft at the time of this printing).

\section{WILD AND SCENIC RIVERS ACT (WSRA)}

The WSRA establishes requirements that apply to water resource projects affecting wild, scenic, or recreational rivers within the National Wild and Scenic Rivers System, as well as rivers designated on the National Rivers Inventory to be studied for inclusion in the National System. For purposes of the Act, a project is a dam, water conduit, reservoir, powerhouse, transmission line, discharge to waters, or other water resources project that would affect the free-flowing characteristics of the water. If a response action could affect the free-flowing characteristics of such a river, the requirement that such action should minimize adverse impacts may be a potential ARAR. Response alternatives should be developed in consultation with DOI (National Park Service) and the Department of Agriculture.

\section{FISH AND WLDLIFE COORDINATION ACT (FWCA)}

The FWCA protects fish and wildlife through the review of actions that control or structurally modify a natural stream or body of water. A potential ARAR under the FWCA is the requirement to consider the effect that such water-related projects would have upon fish and wildlife, and take action to prevent loss or damage-to these resources. While consultation with FWS or NOAA is required under CERCLA only if alteration of the water resource would occur from off-site activities (e.g., a change in the rate of flow), consultation is strongly recommended for on-site activities as well.

\section{E. COASTAL ZONE MANAGEMENT ACT (CZMA)}

The CZMA regulates actions by Federal agencies that directly affect the coastal zone. The Act requires Federal agencies to conduct or support their activities in a manner consistent with approved State coastal zone management programs (CZMPs). The requirement to determine whether a response action will have any effect (whether adverse or not) on the coastal zone of a State with an approved CZMP is a potential ARAR. Specifically, the lead agency is required to determine whether the activity will be consistent, to the maximum extent practicable, with the State's CZMP. The lead agency should notify the State of its determination. Copies of a State's CZMP may be obtained from the State's coastal commission. All coastal States have approved CZMPs except for Georgia, Texas, Ohio, Indiana, Illinois, and Minnesota. For off-site actions that require a Federal permit, the State must certify that the proposed activity complies with its coastal zone management plan (see CZMA section 307(c)(3)).

\section{F. WILDERNESS ACT (WA)}

The WA administers wilderness areas to prese their character and to keep them unimpaired for fu use as wilderness. To comply with ARARs under w. WA, the RPM must first identify whether the response action would affect designated wilderness areas (see 16 USC section 1132). The Regional NEPA Compliance Staff should be able to identify these areas. If a potential impact is anticipated, the RPM should determine whether any prohibitions apply to the proposed response action. To take advantage of their expertise, the RPM should consult with the NEPA Compliance Staff and the administering agency to make this determination. The RPM should then determine whether an exemption is necessary under the WA or CERCLA

\section{G. NATIONAL ENVIRONMENTAL POLICY ACT (NEPA)}

Like the NEPA regulations, the RI/FS and remedy selection process under CERCLA provide for consideration of the potential impacts of CERCLA response actions on the environment, and provide for significant public participation. EPA response actions are not required to follow procedures in addition to those in the NCP in order to comply with NEPA. 


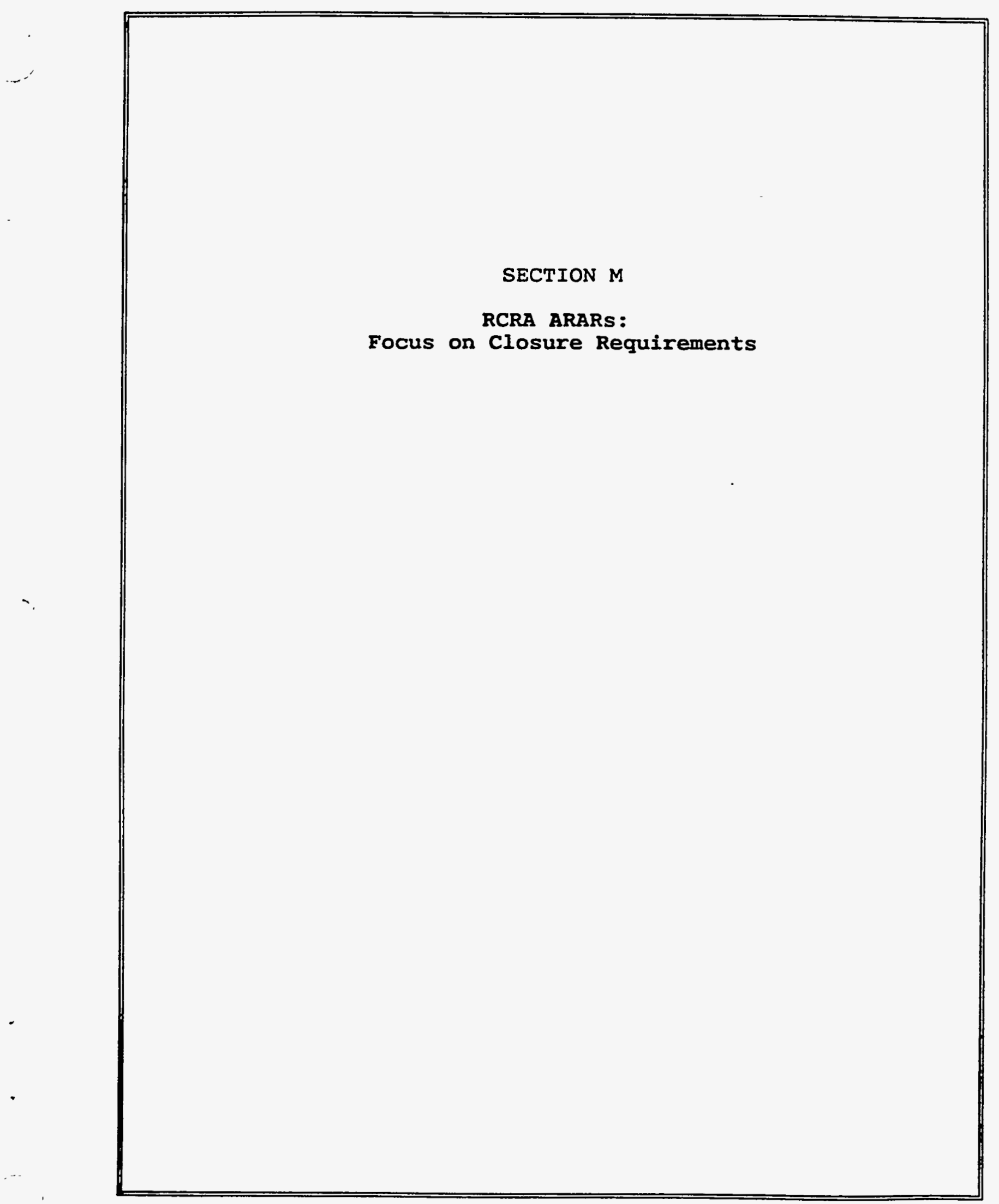


The Superfund Amendments and Reauthorization Act of 1986 (SARA) adopts and expands a provision in the 1985 National Contingency Plan (NCP) that remedial actions must at least attain applicable or relevant and appropriate requirements (ARARs). Section 121(d) of CERCLA, as amended by SARA, requires attainment of Federal ARARs and of State ARARs in State environmental or facility siting laws when the State requirements are promulgated, more stringent than Federal laws, and identified by the State in a timely manner.

To implement the ARARs provision, EPA has developed guidance, CERCLA Compliance with Other Laws Manual: Parts I and II (OSWER Directives 9234.1-01 and 9234.1-02, respectively). EPA is preparing a series of short Fact Sheets (OSWER Directive 9234.2 series) that summarize the guidance documents. This particular Fact Sheet addresses compliance with Subtitle $C$ of the Resource Conservation and Recovery Act (RCRA), as amended by the Hazardous and Solid Waste Amendments of 1984 (HSWA), with a focus on the RCRA Subtitle C closure requirements. This Fact Sheet is based on policies in the proposed December 21, 1988 revisions to the NCP. The final NCP may adopt policies different from those covered here and, when promulgated, should be considered the authoritative source.

\section{AN OVERVIEW OF RCRA SUBTITLE C ARARS}

The provisions of Subtitle C of RCRA mandate "cradle-to-grave" management of hazardous waste, and regulate three types of hazardous waste handlers: (1) generators; (2) transporters; and (3) owners and operators of treatment, storage, or disposal facilities (TSDFs). Although there are RCRA requirements for generators and transporters of hazardous waste, the most extensive RCRA requirements are those for the design, operation, and closure of hazardous waste TSDFs (40 CFR Part 264). Highlight 1 shows the types of hazardous waste management units regulated under Subtitle C.

RCRA Subtitle $C$ requirements for TSDFs will frequently be ARARs for CERCLA actions, because RCRA regulates the same or similar wastes as those found at many CERCLA sites, covers many of the same activities, and addresses releases and threatened releases similar to those found at CERCLA sites. When RCRA requirements are ARARs, only the substantive requirements of RCRA must be met if a CERCLA action is to be conducted on site. On-site actions do not require RCRA permits, nor is compliance with administrative requirements necessary for on-site actions. CERCLA actions to be conducted off site, however, must comply with both substantive and administrative RCRA requirements (see Highlight 2 on the next page).

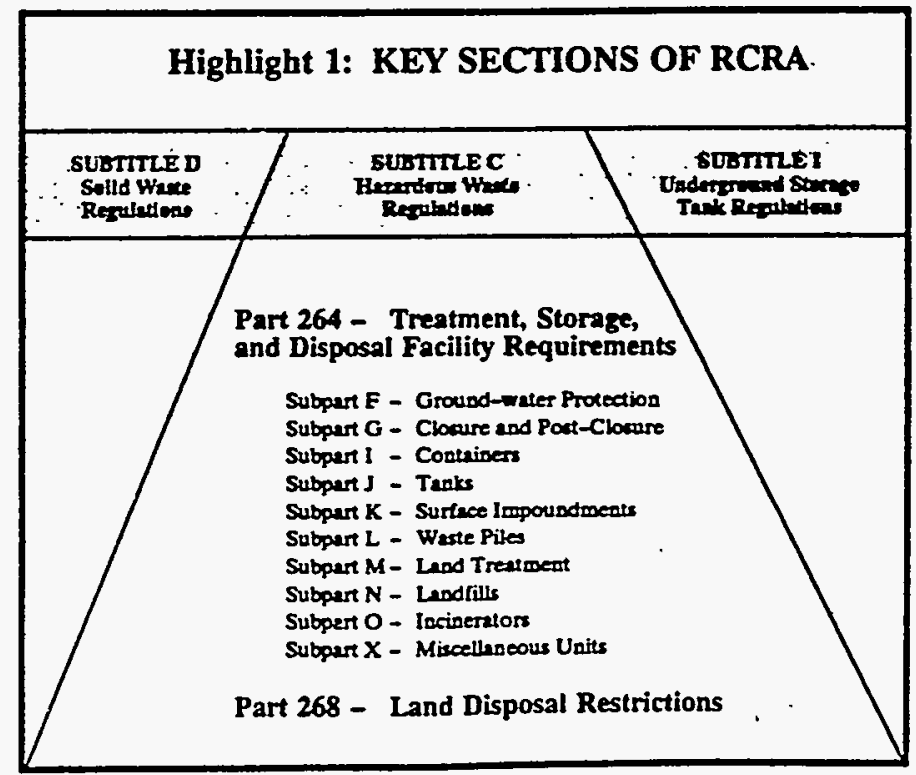




\section{Highlight 2: SUBSTANTTVE AND ADMINISTRATIVE REQUIREMENTS}

Substantive Requirements are those requirements that pertain directly to actions or conditions in the environment. Examples include performance standards for incinerators (40 CFR 264.343), treatment standards for land disposal of restricted waste (40 CFR 268), and concentration limits, such as MCLs.

Administrative Requirements are those mechanisms that facilitate the implementation of the substantive requirements of a statute or regulation. Examples include the requirements for preparing a contingency plan, submitting a petition to delist a listed hazardous waste, recordkeeping, and consultations.

\section{A. WHEN RCRA IS APPLICABLE}

RCRA Subtitle $C$ requirements for the treatment, storage, and disposal of hazardous waste are applicable for a Superfund remedial action if the following conditions are met:

- The waste is a RCRA hazardous waste, and either:

- The waste was initially treated, stored, or disposed of after the effective date of the particular RCRA requirement, or

- The activity at the CERCLA site constitutes treatment, storage, or disposal, as defined by RCRA.

\section{When a CERCLA Waste is a RCRA Hazardous Waste}

In order for RCRA requirements to be applicable, a Superfund waste must be determined to be a listed or characteristic hazardous waste under RCRA (see Highlights $3 \mathrm{a}$ and $3 \mathrm{~b}$ for the definition of RCRA hazardous waste). A waste that is hazardous because it once exhibited a characteristic (or media containing a characteristic waste) will not be subject to Subtitle $C$ regulation if it no longer exhibits the characteristic. A listed waste may be delisted if it can be shown that the specific waste is not hazardous based on the standards in 40 CFR 264.22. If such a waste will be shipped off site, it must be delisted through a rulemaking process. However, to delist a RCRA hazardous waste that will remain on site at a Superfund site, only 'the substantive requirements for delisting must be met (see "ARARs Q's and A's," OSWER Directive 9234.2-01FS, May 1989).

\section{Highlight 3a: CHARACTERISTIC RCRA} HAZARDOUS WASTES

(Subpart C of 40 CFR Part 261)

- Ignitability - i.e., a waste with a flash point lower than $140 \mathrm{~F}$;

- Corrosivity - i.e., a waste with a pH less than or equal to 2.0 or greater than or equal to 12.5 , or capable of corroding steel at a rate of more than 0.25 inches per year;

- Reactivity - i.e., a waste that is explosive, reacts violently with water, or generates toxic gases when exposed to water or liquids that are moderately acidic or alkaline; and

- Extraction Procedure (EP) Toxicity ${ }^{\star}$ - i.e., a waste for which the EP test extract contains a concentration of a specified contaminant above its regulatory threshold.

- A final rulemaking is underway that will replace the EP test with the Toxicity Characteristic Leaching Procedure (TCLP).

Promulgation is expected in 1990.

\section{Highlight 3b: LISTED RCRA HAZARDOUS WASTES \\ (Subpart D of 40 CFR Part 261)}

- F Waste Codes (Part 261.31) - wastes from non-specific sources (e.g., F001 - FO05 spent solvents);

- K Waste Codes (Part 261.32) - wastes from specific sources (e.g., K001 wastewater treatment sludge from wood preserving processes);

- P Waste Codes (Part 261.33(e)) - acutely hazardous commercial chemical products; $*$ and

- U Waste Codes (Part 261.34(f)) - toxic commercial chemical products.*

In addition, any solid waste derived from the treatment, storage, or disposal of a listed waste, and any mixture of solid waste and listed waste is a RCRA hazardous waste (regardless of the concentration of hazardous constituents or the percentage of listed wastes in such a mixture).

"NOTE: The word "product" refers to a commercially pure or technical grade of the chemical. A material does not qualify as a product simply because it is a process waste. 
Any environmental media (i.e., soil or ground water) contaminated with a listed waste is not a hazardous waste, but must be managed as such until it no longer contains the listed waste, generally when constituents from the listed waste are at health-based levels. Delisting is not required.

To determine whether a waste is a listed waste under RCRA, it is often necessary to know the source of that waste. For any Superfund site, if an affirmative determination cannot be made that the contamination is a RCRA hazardous waste, RCRA requirements will not be applicable. A determination of whether a waste is a characteristic waste can be based on testing the waste. Alternatively, best professional judgment (based on knowledge of the waste and its constituents) can be used to determine whether testing is necessary.

\section{When the Date of Initial Disposal Triggers RCRA Applicability}

A RCRA requirement will be applicable if the hazardous waste was treated, stored, or disposed of after the effective date of the particular requirement. The RCRA Subtitle $C$ regulations that established the hazardous waste management system first became effective on November 19, 1980. RCRA regulations will not be applicable to wastes disposed of before that date, unless the CERCLA action itself constitutes treatment, storage, or disposal (see below). Additional standards have been issued since 1980; therefore, applicable requirements may vary somewhat, depending on the specific date on which the waste was disposed.

\section{When Superfund Activities Trigger RCRA Applicability}

RCRA requirements for hazardous wastes will also be applicable if the response activity at the Superfund site constitutes treatment, storage, or disposal, as defined under RCRA. Disposal of hazardous waste, in particular, triggers a number of significant requirements, including closure requirements (see Part II of this Fact Sheet) and land disposal restrictions, which require treatment of wastes prior to land disposal. (See Guides on Superfund Compliance with Land Disposal Restrictions, OSWER Directives 9347.3-01FS through 9237.3-06FS, for a detailed description of these requirements.)

Because remedial actions frequently involve grading, excavating, dredging, or other measures that disturb contaminated material, activities at Superfund sites may constitute disposal, or placement, of hazardous waste (see Highlight 4).

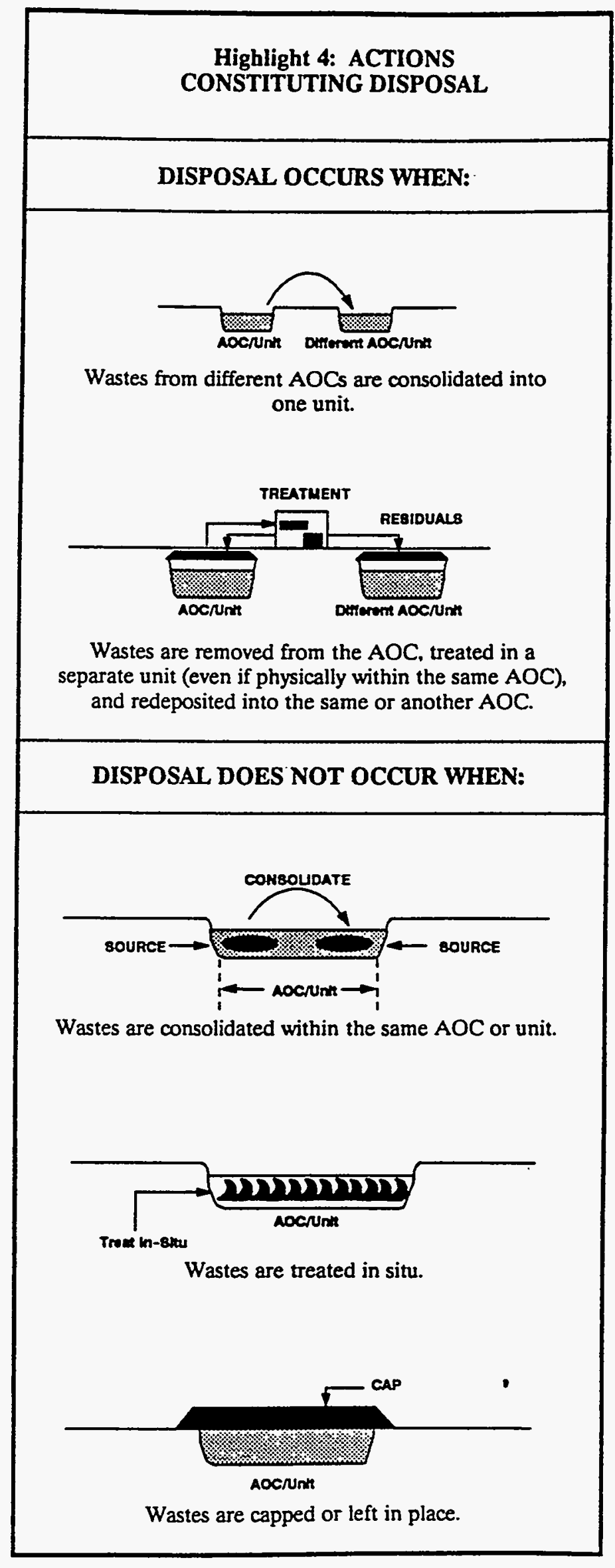


EPA has determined that disposal occurs when wastes are placed in a land-based unit. However, movement within a unit does not constitute disposal or placement, and, at CERCLA sites, an area of contamination (AOC) can be considered to be comparable to a unit. Therefore, movement within an $A O C$ does not constitute placement.

\section{B. WHEN RCRA IS RELEVANT AND APPROPRIATE}

RCRA requirements that are not applicable may, nonetheless, be relevant and appropriate, based on site-specific circumstances. For example, if the source or prior use of a CERCLA waste is not identifiable, but the waste is similar in composition to a known, listed RCRA waste, the RCRA requirements may be potentially relevant and appropriate, depending on other circumstances at the site.

However, the similarity of the waste at the CERCLA site to RCRA waste is not the only, nor necessarily the most important, consideration in the determination. An in-depth, constituent-by-constituent analysis is generally neither necessary nor useful, since most RCRA requirements are the same for a given activity or unit, regardless of the specific composition of the hazardous waste.

The determination of relevance and appropriateness of RCRA requirements is based on the circumstances of the release, including the hazardous properties of the waste, its composition and matrix, the characteristics of the site, the nature of the release or threatened release from the site, and the nature and purpose of the requirement itself. Some requirements may be relevant and appropriate for certain areas of the site, but not for other areas. In addition, some RCRA requirements may be relevant and appropriate at a site, while others are not, even for the same waste. For example, minimum technology requirements may be considered relevant and appropriate for one area receiving waste because of the high potential for migration of contaminants in hazardous levels to ground water, but not for another area that contains relatively immobile waste. Land disposal restrictions may be determined not to be relevant and appropriate for either area because the treatment technology required by the requirement is not appropriate, given the matrix of the waste. Only those requirements that are determined to be both relevant and appropriate must be attained.

\section{STATE AUTHORIZATION UNDER RCRA}

A State may be authorized to administer the RCRA hazardous waste program in lieu of the Federal program provided that the State has equivalent authority. Authorization is granted separately for the basic RCRA Subtitle C program, which includes permitting and closure of TSDFs; for regulations promulgated pursuant to HSWA, such as land disposal restrictions; and for other programs, such as delisting of hazardous wastes. If a site is located in a State with an authorized RCRA program, the State's promulgated RCRA requirements will replace the equivalent Federal requirements as potential ARARs.

An authorized State program may also be more stringent than the Federal program. For example, a State may have more stringent test methods for characteristic wastes, or may list more wastes as hazardous than the Federal program does. Therefore, it is important to determine whether laws in an authorized State go beyond the Federal regulations. 


\section{FOCUS ON RCRA CLOSURE REQUIREMENTS}

For each type of unit regulated under RCRA, Subtitle $C$ regulations contain closure standards that must be met when a unit is closed. For treatment and storage units, the standards require that all hazardous waste and hazardous waste residues be removed when the unit is closed. In addition to the option of closure by removal, called "clean closure," units such as landfills, surface impoundments, and waste piles may be closed as disposal or landfill units with waste in place, referred to as "landfill closure." Frequently, the closure requirements for such landbased units will be either applicable or relevant and appropriate at Superfund sites.

\section{A. WHEN CLOSURE REOUIREMENTS ARE APPLICABLE}

The basic prerequisites for applicability of closure requirements are: (1) the waste must be a hazardous waste; and (2) the unit (or AOC) must have received waste after the RCRA requirements became effective, either because of the original date of disposal or because the CERCLA action constitutes disposal (described in Part I of this Fact Sheet). When RCRA closure requirements are applicable, the regulations allow only two types of closure: (1) clean closure; and (2) disposal or landfill closure.

Highlight 5 provides a description of each type of closure. Clean closure standards assume there will be unrestricted use of the site and require no maintenance after the closure has been completed, and are often referred to as the "eatable solid, drinkable leachate" standards. In contrast, disposal or landfill closure standards require post-closure care and maintenance of the unit for at least 30 years after closure. EPA has prepared several guidance on closure and final covers (e.g., the draft RCRA Guidance Manual for Subpart G, Closure and PostClosure Standards, EPA-530-SW-78-010, and the technical guidance document, Final Covers on Hazardous Waste Landfills and Surface Impoundments, EPA 530-SW-89-047, July 1989). These guidance documents are not ARARs, but are to be considered (TBC) for CERCLA actions and may assist in complying with these regulations. Of course, the performance standards in the regulation may be attained in ways other than that described in guidance, depending on the specific circumstances of the site.

\section{Highlight 5: REQUIREMENTS FOR CLEAN AND LANDFILL CLOSURE}

Clean Closure: All waste residues and contaminated containment system components (e.g., liners), contaminated subsoils, and structures and equipment contaminated with waste and leachate must be removed and managed as hazardous waste or decontaminated before the site management is completed, "edible soil, drinkable leachate" [see 40 CFR 264.111, 264.228(a)].

Landfill Closure: The unit must be capped with a final cover designed and constructed to:

- provide long-term minimization of migration of liquids;

- function with minimum maintenance;

- promote drainage and minimize erosion;

- accommodate settling and subsidence; and

- have a permeability less than or equal to any bottom liner system or natural subsoils present.

Post-closure care includes maintenance of the final cover; operation of a leachate and removal system; and maintenance of a groundwater monitoring system [see 40 CFR 264.117, 264.228(b)].

\section{B. WHEN CLOSURE REQUIREMENTS ARE RELEVANT AND.APPROPRIATE}

If they are not applicable, RCRA closure requirements may be relevant and appropriate. However, there is more flexibility in designing closures because a hybrid closure is possible. Hybrid closure occurs when only certain requirements in the closure standards are relevant and appropriate. Depending on the site circumstances and the remedy selected, either clean closure, landfill closure, or a combination of both may be used. 
The proposed revisions to the NCP discuss the concept of hybrid closure (53 FR 51446). The NCP illustrated the following possible hybrid closure approaches: (1) hybrid-clean closure; and (2) hybridlandfill closure, which combines elements of clean closure and closure with waste in place, as described in Highlight 6.

\section{Highlight 6: HYBRID-CLEAN AND HYBRD-LANDFILL CLOSURES}

Bybrid-Clean Closure: Used when leachate will not impact the ground water (even though residual contamination and leachate are above health-based levels) and contamination does not pose a direct contact threat.

- No covers or long-term management are required;

- Fate and transport modeling and model verification are used to ensure that ground water is usable; and

- A property deed notice is used to indicate the presence of hazardous substances.

Bybrid-Landfill Closure: Used when residual contamination poses a direct contact threat, but does not pose a ground-water threat.

- Covers, which may be permeable, are used to address the direct contact threat;

- Limited long-term management includes site and cover maintenance and minimal ground-water monitoring;

- Institutional controls (e.g., land-use restrictions or deed notices) are used as necessary.
The two hybrid closure alternatives are constructs of applicable laws but are not themselves promulgated at this time. These alternatives are possible when RCRA requirements are relevant and appropriate, but are not available when closure requirements are applicable.

\section{AFTERWORD: MINIMUM TECHNOLOGY REQUTREMENTS}

While every unit to which RCRA applies must be closed in accordance with RCRA closure requirements (as discussed in Part II of this Fact Sheet), the minimum technology requirements (MTR) apply only to a subset of these regulated units. The MTR require installation of double liners and a leachate collection system, in addition to compliance with other design standards.

The MTR apply only to new units, replacement units, ${ }^{a}$ and lateral expansions of existing landfills (40 CFR 254.301(c)) and surface impoundments (40 CFR $254.221(c))$. $^{b, c}$ Therefore, an existing landfill or AOC would not be subject to MTR, even if disposal of hazardous waste occurred as part of the CERCLA action. The unit or AOC would, however, be subject to RCRA closure standards for landfills. Although not applicable, MTR may be relevant and appropriate depending on the circumstances of the release and the site.

${ }^{a}$ A replacement unit is further defined as an existing unit that meets the following criteria: (1) the unit is taken out of service; (2) all or substantially all of the waste is removed; and (3) the unit is reused, which does not include removal and replacement of waste into the same unit.

b In addition, as of November 19, 1988, existing surface impoundments that actively receive wastes must be retrofitted to comply with MTR (with some limited exceptions).

${ }^{c}$ LDR requires that certain restricted wastes, such as soft hammer wastes, be disposed of in a unit that meets MTR, and therefore can trigger MTR indirectly (see Superfund LDR Guide \#3, OSWER Directive 9347.3-03FS). 


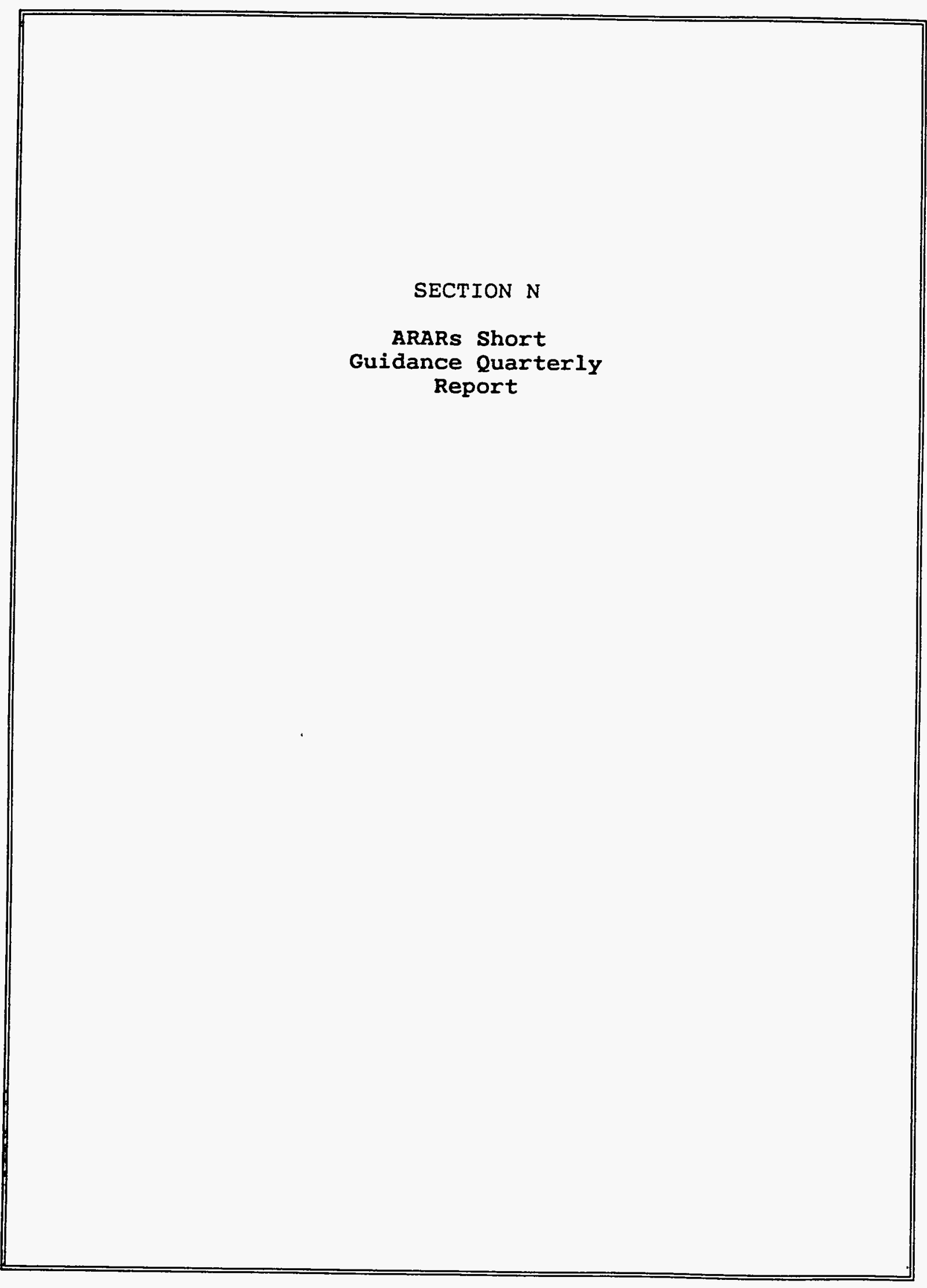




\section{United States \\ Environmental Protection \\ Office of \\ Solid Waste and \\ Agency \\ Emergency Response \\ \&EPA \\ ARARs Short Guidance Quarterly Report}

Publication 9234.3-00I

December 1989

Office of Emergency and Remedial Response Office of Program Management OS-240

The ARARs Short Guidance Quarterly Report provides an annotated description of all published short guidance on ARARs. Short guidance documents on ARARs include Fact Sheets, Q's \& A's, Memoranda resolving ARARs issues, and the Guide to the CERCLA Compliance with Other Laws Manual. Each Quarterly Report is comprehensive to date, and each item below is final unless otherwise noted. The ARARs short guidance documents are designed to supplement, not supplant, the CERCLA Compliance with Other Laws Manual. This report will expressly note any ARARs short guidance that supercedes information provided in the CERCLA Compliance with Other Laws Manual. Single copies of all of these short guidance documents may be obtained by calling or writing the Superfund Docket and Information Center, U.S. EPA, OS-245, 401 M St. SW, Washington, DC 20460; (202) or FTS 382-6940. Copies of the CERCLA Compliance with Other Laws Manual (Part I -- EPA/540/G-89/006, Part II -- EPA/540/G-89/009) may be obtained from CERI, U.S. EPA, 26 West Martin Luther King Drive, Cincinnati, $\mathrm{OH} 45268$; (513) 569-7562.

\section{ARARs Q's and A's}

Publication 9234.2-01/FS

May 1989

4 pages

The ARARs Q's \& A's Fact Sheet (first in an expected series of Q's \& A's) addresses seven general ARARs policy questions, such as: (1) the distinction between "applicable" and "relevant and appropriate" requirements; (2) whether ARARs that are not required for protectiveness have to be met; and (3) whether environmental resource laws such as the Endangered Species Act are potential ARARs. The Q's \& A's also discusses three RCRA ARARs issues: (1) RCRA delisting when wastes remain on-site; (2) RCRA financial responsibility requirements as potential ARARs; and (3) the applicability of minimum technology requirements for existing hazardous waste pits closed before 1980. Finally, the Q's \& A's addresses four ARARs questions arising from the Clean Water Act and the Safe Drinking Water Act; one question addresses ground-water antidegradation laws and three focus on MCLS and MCLGs.

\section{Guide to Manual}

Publication 9234.2-02/FS

September 1989

2 pages

The Guide to Manual Fact Sheet describes the overall purpose of the CERCLA Compliance with Other Laws Manual: Parts I and II. It also serves as a table of contents to the manual by describing the contents of each chapter of both parts of the manual. 


\section{ARARS SHORT GUIDANCE QUARTERLY REPORT (cont'd)}

RCRA ARARs: Focus on Closure Requirements

October 1989
Publication 9234.2-04/FS

5 pages

The RCRA ARARs Fact Sheet provides an overview of RCRA Subtitle C ARARs and describes when RCRA requirements are ARARs. The Fact Sheet also focuses on RCRA closure requirements, discussing when RCRA closure requirements are ARARs, and what the RCRA minimum technology requirements encompass. The elements and consequences of State authorization under RSRA are also summarized.

Superfund LDR Guide \#1, Overview

Publication 9347.3-01/FS of RCRA LDRs

July 1989

4 pages

The LDR Overview Fact Sheet defines land disposal, describes the RCRA LDR statutory deadlines, and summarizes statutory waste categories. Other topics discussed include: types of LDR restrictions, LDR compliance options, and soil and debris wastes. Finally, it addresses other LDR requirements, including storage prohibitions, exemptions for treatment in surface impoundments, dilution prohibitions, and LDR testing, notification, and compliance certification requirements.

\section{Superfund LDR Guide \#2, Complying with the \\ Publication 9347.3-02/FS California List Restrictions under LDR \\ July 1989 \\ 2 pages}

The LDR California List Restrictions Fact Sheet defines California List Wastes, describes the California List LDR restrictions, and summarizes the overlap between California List LDR restrictions and other treatment standards. The Fact Sheet also provides a chart that sets forth prohibition levels and treatment standards for California List Wastes. 


\section{ARARS SHORT GUIDANCE \\ QUARTERLY REPORT (cont'd)}

Superfund LDR Guide \#3, Treatment Standards and Minimum Technology Requirements under LDR

July 1989

Publication 9347.3-03/FS

4 pages

The LDR Treatment Standards and Minimum Technology Requirements Fact Sheet describes the three types of treatment standards (concentration levels, specified technologies, and no land disposal) and discusses the two types of tests for evaluating compliance with LDR treatment standards (the Total Waste Analysis and the Toxicity Characteristic Leaching Procedure). The Fact Sheet also reviews treatment standards in effect for RCRA hazardous wastes, and explains minimum technology requirements that apply during a national capacity extension. Charts illustrate effective dates and LDR restrictions for Solvents and Dioxins, California List Wastes, and certain First Third Wastes.

\section{Superfund LDR Guide \#4, Complying with Hammer Publication 9347.3-04/FS Restrictions under LDR}

July 1989

4 pages

The LDR Hammer Restrictions Fact Sheet discusses soft hammer wastes, restrictions, and requirements for notifications, certifications, and demonstrations. Other topics include the overlap between California List Wastes, soft hammer wastes, and hard hammer wastes. The Fact Sheet also highlights soft hammer notification, certification, and demonstration requirements, hard hammer deadlines, and the process for identifying soft hammer waste restrictions.

\section{Superfund LDR Guide \#5, Determining when LDRs Publication 9347.3-05/FS are Applicable}

July 1989

\section{4 pages}

The LDR Applicability Fact Sheet addresses three questions: (1) Does the response constitute placement? (2) Is the CERCLA substance a RCRA hazardous waste? and (3) Is the RCRA waste restricted under the LDRs? In addition, the Fact Sheet provides examples of areas of contamination (AOCs), highlights L.DR statutory deadlines, and illustrates the process of determining when LDRs are applicable requireme 7 ts. 


\title{
ARARS SHORT GUIDANCE QUARTERLY REPORT (cont'd)
}

\section{Superfund LDR Guide \#6A, Obtaining a Soil and Debris Treatability Variance for Remedial Actions} July 1989

\section{Publication 9347.3-06/FS}

6 pages

The LDR Soil and Debris Treatability Variance Fact Sheet discusses the basis for a treatability variance, describes how to obtain a treatability variance for soil and debris wastes, and summarizes compliance with a treatability variance for soil and debris wastes. The Fact Sheet also highlights information to be included when documenting a soil and debris treatability variance in an RI/FS report for on-site and offsite CERCLA response actions. Sample language concerning treatability variances is provided for the Proposed Plan and Record of Decision (ROD). A chart illustrates alternate treatability variance levels and technologies established by EPA for structural/functional groups. The Fact Sheet also highlights stages in the RI/FS process when LDRs are evaluated, and the identification of treatment levels for a treatability variance.

\section{Memorandum of Applicability of LDRs to RCRA and CERCLA GW Treatment Reinjection}

December 1989

Publication 9234.1-06

\author{
(December 1989
}

This Memorandum establishes that LDR is not applicable to underground disposal of hazardous waste into Class IV injection wells during CERCLA response actions or RCRA corrective actions. The Memorandum explains that because LDR is not applicable, BDAT does not have to be met prior to each reinjection or at the completion of the action in a pump-and-treat reinjection remediation system. The Memorandum additionally explains why LDRs generally will not be relevant and appropriate requirements for CERCLA response actions that involve ground-water reinjection.

\section{Overview of ARARs - Focus on ARAR Waivers}

December 1989

Publication 9234.2-03/FS

$$
5 \text { pages }
$$

The Overview ARARs Fact Sheet defines ARARs and To Be Considered (TBCs). It additionally focuses on ARARs waivers by describing each waiver and providing waiver examples. Other topics discussed include: (1) factors for identifying relevant and appropriate requirements; (2) "freezing" ARARs at the ROD; (3) compliance with ARARs for on-site versus off-site actions; (4) types of ARARs; and (5) ARARs documentation. 


\section{ARARS SHORT GUIDANCE \\ QUARTERLY REPORT (cont'd)}

CERCLA Compliance with State Requirements

December 1989
Publication 9234.2-05/FS

5 pages

The CERCLA Compliance with State Requirements Fact Sheet describes the statutory requirements for State ARARs and defines such terms as "promulgated" and "more stringent." The Fact Sheet additionally discusses policies with respect to the applicability of some typical State environmental or facility siting laws. It also discusses roles of lead and support agencies with respect to the identification of ARARs, and procedures to be followed when communicating ARARs. 


\section{$\begin{array}{ll}\text { United States } & \text { Office of } \\ \text { Environmental Protection } & \text { Solid Waste and }\end{array}$ \\ Agency Emerjency Response \\ SEPA \\ ARARs Short Guidance Quarterly Report}

Publication 9234.3-001

March 1990

Office of Emergency and Remedial Response

Office of Program Management OS-240

Intormittent Bullotin

Volume 1 Number 2

The ARARs Shor Guidance Quarterty Reports provide an annotated description of all published short guidance on ARARs. Short guidance documents on ARARs include Fact Sheets, Q's \& A's, Memoranda resolving ARARs issues, and the Guide to the CERCLA Compliance with Other Laws Manual. Each Quarterly Report is comprehensive within that quarter, and each item below is final unless otherwise noted. The ARARs short guidance documents are designed to supplement, not supplant, the CERCLA Compliance with Other Laws Manual. This report will expressly note any ARARs short guidance that supercedes information provided in the CERCLA Compliance with Other Laws Manual. Single copies of the previous Quarterty Report and these short guidance documents may be obtained by calling or writing the Superfund Docket and Information Center, U.S. EPA, OS-245, 401 M St. SW, Washington, DC 20460; (202) or FTS 382-6940. Copies of the CERCLA Compliance with Other Laws Manual (Pant I - EPA540/G-89/006, Part II - EPA540/G-89/009) may be obtained from CERI, U.S. EPA, 26 West Martin Luther King Drive, Cincinnati, OH 45268; (513) 569-7562.

Superfund LDR Guide \#7, Determining

Publication $9347.3-08 / F S$

When LDRs are Relevant and Appropriate to CERCLA Response Actions

December 1989

2 pages

The LDR Relevant and Appropriate Fact Sheet discusses the four pertinent factors to compare when determining the relevance and appropriateness of LDRs: (1) the action or activities regulated by the requirement and the remedial action contemplated; (2) the purpose of the requirement and the purpose of the CERCLA response action; (3) the substances regulated by the requirement and the substances found at a CERCLA site; and (4) the medium regulated or affected by the requirement and the medium contaminated or affected at the CERCLA site.

The CWA and SDWA Fact Sheet provides an overview of potential ARARs from the Clean Water ACt for direct and indirect discharges to surface water, as well as dredge-and-fill requirements. This fact sheet also describes potential ARARs from the Safe Drinking Water Act such as MCLs, MCLGs, SMCLs, as well as substantive provisions from the Underground Injection Control program. In the final section, potentially conflicting ARARs concerning surface water from the CWA and SDWA are listed and resolutions are provided. 


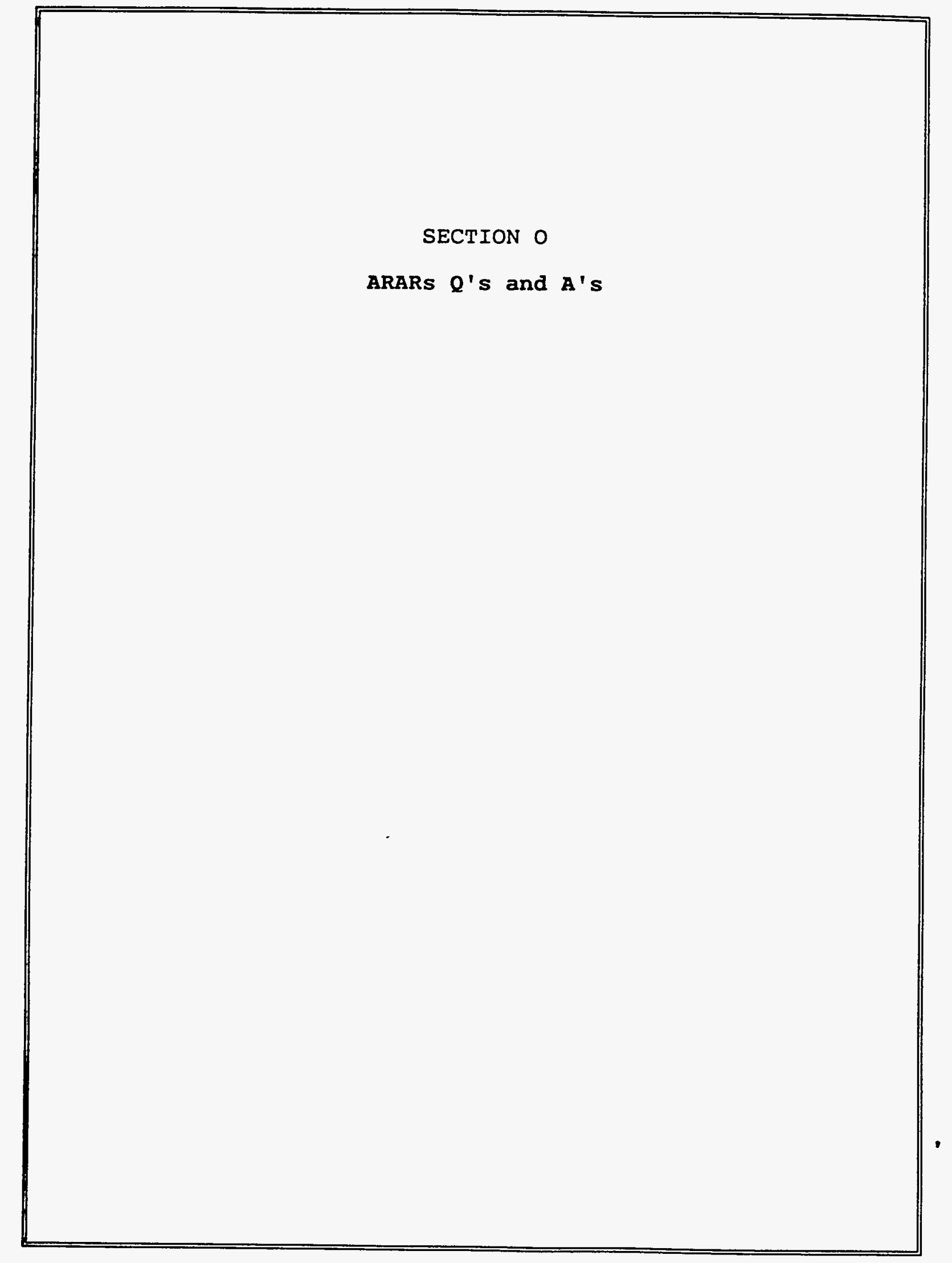




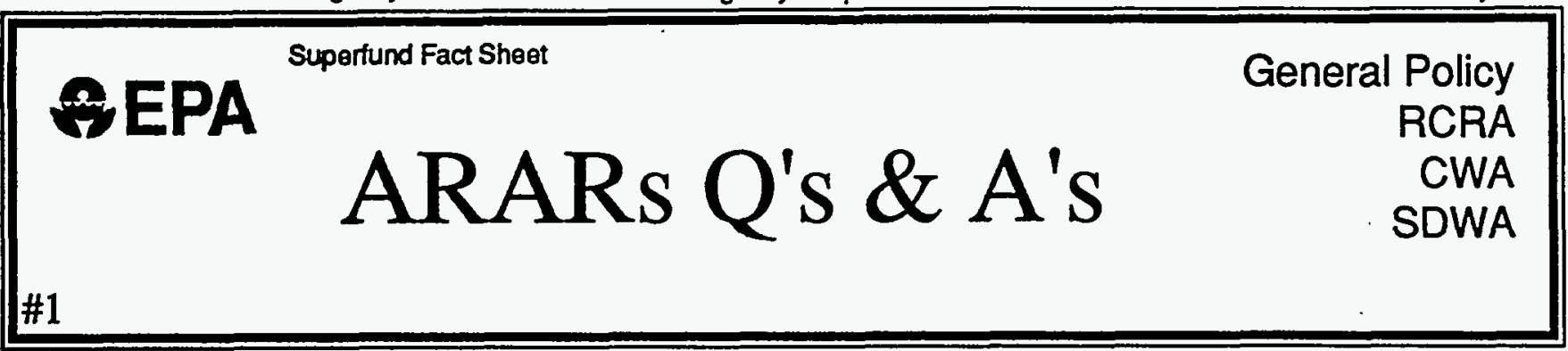

The 1986 Superfund Amendments and Reanthorization Act (SARA) adopts and expands a provision in the 1985 National Contingency Plan (NCP) that remedial actions must at least attain applicable or relevant and appropriate requirements (ARARs). In section 121(d). SARA requires attainment of Federal ARARs, and of State ARARs in State environmental or facility siting laws when the requirements are promulgated, more stringent than Foderal laws, and identified by the State in a timely manner. Under EPA regulation and policy, removal actions must comply with ARARs to the extent precticable.

To implement the ARARs provision, EPA has developed guidance, the CERCLA Complianse With Other Laws Manual (OSWER Directive 9234.101), and has provided training to Regions and States on identification of and compliance with ARARs. These "ARARs Q's and A's" are part of a series that provide answers to a number of questions that arose in developing ARARs policies, in ARARs training sessions, and in identifying and complying with ARARs at specific sites. Responses covered here reflect current program practice and include policies and language from the proposed NCP. Changes resulting from finalizing the NCP following public comment may alter some policies or language quoted from the proposed NCP.

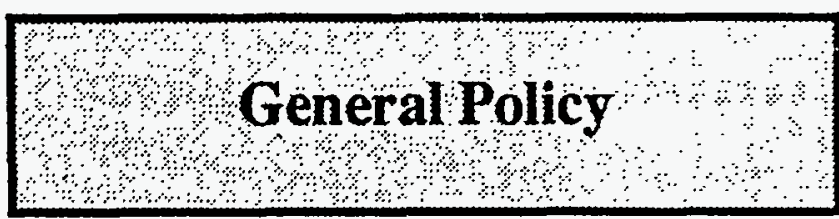

\section{DEFINITIONS OF “APPLICABLE" AND "RELEVANT AND APPROPRIATE"}

"Applicable reouirements mean those cleanup standards, standards of control, and other substantive environmental protection requirements, criteria, or limitations promulgated under Federal or State law that specifically address a hazardous substance, pollutant, contaminant, remedial action, location, or other circumstance at a CERCLA site." [Proposed NCP, 53 ER 51435, December 21, 1988] In other words, an applicable requirement is one that a private party would have to comply with by law if the same action was being taken apart from CERCL A authority. All jurisdictional prerequisites of the requirement must be met in order for the requirement to be applicable.

If a requirement is not applicable, it still may be relevant and appropriate. "Relevant and appropriate_remire: ments mean those cleanup standards [that]... address problems or situations sufriciently similar to those encountered at the CERCLA site that their use is well anited to the particular site." [Proposed NCP, 53 ER 51436, December 21, 1988] A requirement that is relevant and appropriate may "miss" on one or more prerequisite bur still make sense at the site, given the circumstances of the site and release.
Q1. What difference does it make if a requirement is "applicable" or "relevant and appropriate"? Why make that distinction?

A. While it is true that once a requirement is determined to be relevant and appropriate, it must be complied with as if it were applicable, there are significant differences in the identification and analysis of the two types of requirements. The "applicability" determination is a legal one, while the determination of "relevant and appropriate" relies on professional judgment, considering environmental and technical factors at the site. There is more flexibility in the relevance and appropriateness determination: a requirement may be "relevant," in that it covers situations similar to that at the site, but may not be "appropriate" to apply for various reasons, and therefore not well suited to the site. In some situations, only portions of a requirement or regulation may be judged relevant and appropriate; if a requirement is applicable, all substantive parts must be followed.

For example, if closure requirements under Subtitle $C$ of RCRA are applicable (e.g., a landfill that received RCRA hazardous waste after 1980 or where the Superfund action constitutes disposal of hazardous waste), the landfill must be closed in compliance with one of the closure options available in Subtitle $\mathrm{C}$ regulations. These options are closure by removal (clean closure), which requires decontamination to health-based levels, or closure with waste in place (landfill closure), which requires impermeable caps end long-term maintenance.

However, if Subtitle $C$ closure requirements are not applicable, then a "hybrid closure," which includes other types of closure designs, could also be used. The hybrid closure option arises from a determination that only certain closure requirements in the two Subtitle C closure alternatives are relevant and appropriate. (See proposed NCP, 53 ER 
51446, for further discussion of RCRA closure requirements and the concept of hybrid closure.)

Q2. Does an applicable requirement take precedence over one that is relevant and appropriate? In other words, if an applicable requirement is available, will that be the ARAR, rather than one that might otherwise be relevant and appropriate?

A. No, a requirement may be relevant and appropriate even if another requirement legally applies to that situation, particularly when the applicable requirement is not really designed to address the type or magnitude of problems encountered at Superfund sites. For example, RCRA Subtitle D requirements for covers for solid waste facilities may be applicable when RCRA hazardous waste is not present at the site. However, the soil cover required under Subtitle $D$ may not always be sufficient to limit leachate at a Superfund site with substantial amounts of waste similar to RCRA hazardous waste. In such a situation, some Subtitle $C$ closure requirements may be relevant and appropriate to some parts of the site, even though Subtitle D requirements legally apply.

However, one factor that affects whether a requirement is relevant and appropriate is whether another requirement exists that more fully matches the circumstances at the site. In some cases, this might be a requirement that was directly intended for, and is applicable to, the particular situation. For example, Federal Water Quality Criteria will generally not be relevant and appropriate when there is an applicable State Water Quality Standard promulgated specifically for the pollutant and water body, which therefore "more fully matches" the situation.

\section{Q3. Is compliance with ARARs required for a "no action"decision?}

A. No. Section 121 cleanup standards, including compliance with ARARs, apply only to remedial actions the Agency determines should be taken under CERCLA Section 104 and 106 authority. A "no action" decision can only be made when no remedial action is necessary to reduce, control, or mitigate exposure because the site or portion of the site is already protective of human health and the environment. See Guidance on Preparing Superfund Decision Documents (OSWER Directive 9355.3-02) for further discussion of "no action" decisions.

Q4. Does an ARAR always have to be met, even if it is not necessary to ensure protectiveness?

A. Yes. Attainment of ARARs is a "threshold requirement" in SARA, as is the requirement that the remedies be protective of human health and the environment. If a requirement is applicable or relevant and appropriate, it must be met, unless one of the six waivers is used. ARARs represent the minimum that a remedy must attain; it may sometimes be necessary to go beyond what ARARs require to ensure that a remedy is protective.

\section{ON-SITE VS. OFF-STTE ACTIONS}

The requirements under CERCLA for compliance with other laws differ in two significant ways for on-site and off-site actions. First, the ARARs provision only applies to on-site actions; off-site actions must comply fully only with any laws that legally apply to that action. Therefore, off-site actions need only comply with "applicable" requirements, not with "relevant and appropriate" requirements; ARAR waivers are not available for requirements that apply to off-site actions.

Second, on-site actions must comply only with the substantive portions of a given requirement, or those that pertain directly to actions or conditions in the environment; on-site activities need not comply with administrative requirements, such as obtaining a permit or recordkeeping and reporting. Off-site actions must comply with both substantive and administrative requirements.

Q5. If wastes from non-contiguous sites are combined on one site for treatment, is the treatment viewed as off-site activity, and the unit therefore subject to permitting?

A. Sites may be combined for remedial action if it is costeffective to do so and the following statutory criteria [CERCLA Section 104(d)(4)] are met: the sites must be geographically close or pose similar threats to public heal th and the environment. Combined remedies must also be cost-effective and should not result in any significant additional short-term impacts on public health and the environment. The combined remedial action constitutes on-site action, and compliance with permitting or other administrative requirements would not be required. (See OSWER Directive 9347.0-1 and 40ER 37076, September 21, 1984)

\section{Q6. Are environmental resource laws, such as the Endangered Species Act, the National Historic Preservation Act (NHPA), and the Wild and Scenic Rivers Act, potential ARARs for CERCLA aCtions?}

A. Yes, requirements in these laws are potential ARARs. However, these laws frequently require consultation with and, under some laws, concurrence of other Agencies or groups, such as the Fish and Wildlife Service or the Advisory Council on Historic Preservation. Administrative requirements such as consultation or obtaining approval are not required for on-site actions. However, it is strongly recommended that the lead agency nevertheless consult with the administering agencies to ensure compliance with substantive requirements, e.g., the NHPA requirement that actions must avoid or minimize impacts on cultural resources. 


\section{Q7. Are environmental standards and requirements of indlan tribes potential ARARs?}

A. Yes. Indian tribal requirements as potential ARARs for CERCLA actions taken on tribal lands are treated consistently with State requirements. Tribal requirements that meet the eligibility criteria for State ARARs, i.e., they are promulgated (legally enforceable and of general applicability) and more stringent than Federal requirements, are potential ARARs.

\section{Resource Conservation and} Recovery Act (RCRA)

Q8. How can RCRA listed waste be "delisted" when wastes will remain on-site?

A. If a listed waste is "delisted," it is no longer considered a "hazardous waste" and is subject to Subtitle D requirements for solid waste, rather than the more stringent Subtitle C requirements.

Only the substantive requirements for delisting a RCRA hazardous waste must be met for wastes that will remain on-site and will not be handled as hazardous. These are the standards in 40 CFR 260.22(a)(1) and (2), which state that a waste that "does not meet any of the criteria under which the waste was listed as a hazardous or an acutely hazardous waste" and for which there is no "reasonable basis to believe that factors (including other constituents) other than those for which the waste was listed could cause the waste to be a hazardous waste" is 'delistable.' Administrative requirements, which include requirements to undergo a petition and rulemaking process and to develop and supply specific information, need not be met on-site.

Wastes containing constituents at health-based levels, assuming direct exposure, will meet the standards for delisting. Wastes with constituents at higher levels may also be delistable, since the RCRA delisting process allows fate and transportmodeling, generally based on the waste being managed in a solid waste facility. The models used by the RCRA program for delisting should be used in determining whether constituent concentrations above health-based levels are delistable, c.g., for wastes that will be land rdisposed (See 50 ER 4886, November 27, 1985 and 51 ER 41082, November 13, 1986). The Assistance Branch in the Office of Solid Waste can also provide assistance and advice in delisting a waste.

The expectation that the waste will meet delisting levels rhould bo documented in the RI/FS and the ROD and * upported by information comparable to that required for delisting, as appropriate for the waste and site (see the : guidance "Retitions to Delist Hazardous Waste "EPA 530SW-85-003, April 1985). Generally, the constituentlevels that must be achieved in order for the waste to be consid- ered non-hazardous should be identified in the ROD. Unless treatability studies done during the RI/FS make delisting reasonably certain, the ROD should also address how the waste will be handled if it does not achieve delistable levels, based on full-scale treatability studies or actual performance of the remedy during $R D / R A$. If the waste cannot be delisted, an explanation of significant differences should be issued to notify the public that the contingency remedy will be implemented.

\section{Q9. Are RCRA financial responsibility requirements potential ARARs for Superfund?}

A. No, because they do not pertain directly to actions or conditions in the environment. Rather, the requirements support implementation of RCRA technical standards by ensuring that RCRA facility owners or operators have the financial resources available to address releases and comply with closure and post-closure requirements. CERCLA agreements with PRPs, and ultimately the Fund itself, achieve essentially the same purpose.

Q10. RCRA hazardous waste is placed into an existing pit that had received hazardous waste in the past, but is not subject to RCRA Subtitle Cregulations because the pit closed before 1980. Would the minimum technology requirements (MTR) be applicable for the pit because it is a "new unit"?

A. No, the pit is not considered a "new unit." MTR will not apply when disposing of waste in an existing unit or area of contamination, although a lateral expansion of the unit would have to meet MTR. (Note: both new and existing surface impoundments are subject to MTR if they receive waste after November 1988. In addition, the land disposal restrictions (LDR) can trigger MTR indirectly. LDR restricts placement of a "soft hammer" waste and a restricted waste under a capacity variance to units in compliance with MTR. If such a waste is placed in the existing waste pit, the pit would have to comply with MTR, even though it is not a "new unit.")

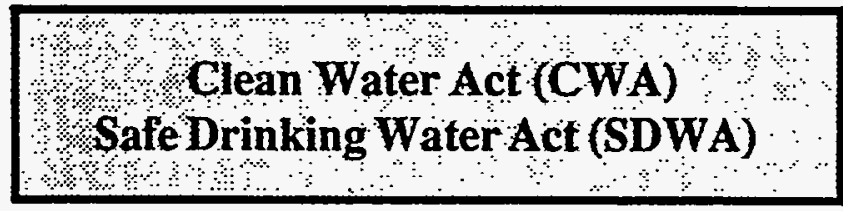

Q11. Do antidegradation laws for ground water, increasingly common in State laws, mean that the aquifer must be restored to its original $\Rightarrow$ quality before contamination from the site occurred?

A. Generally, antidegradation laws are prospectiveand are intended to prevent further degradation of water quality. At n aCERCLA site, therefore, a State ground water antidegradation law might preclude the injection of partially treated 
water into a pristine aquifer. It would not, however, require cleanup to the aquifer's original quality prior to contamination, nor would it preclude reinjection of partially treated water back into the already contaminated portion of the aquifer, as long as the reinjection does not increase the existing level of contamination.

\section{ARARS FOR GROUND WATER CLEANUP}

MCLs promulgated under SDWA generally will be the relevant and appropriate standard for ground water that is or may be used for drinking, considering its use, value, and vulnerability as described in the EPA's Ground-water Protection Strategy (August 1984), e.g., for Class I and II aquifers.

Q12. There are some situations where an aquifer that is a current or potential drinking water source, treatable to MCLs at the tap, cannot be remediated to MCLs in the aquifer, e.g., where background levels of contaminants are above MCLs. Would MCLs still be relevant and appropriate?

A. The MCLs are generally relevant and appropriate for any aquifer that is a potential drinking water source. If the MCLs cannot be attained (e.g., because of complex hydrogeology due to fractured bedrock), an ARAR waiver for technical impracticability should be used. The same approach should be followed if attainment of MCLs is impracticable because background levels of chemicals subject to CERCLA authority (e.g., man-made chemicals) arehigher than MCLs, and no area-wide remediation of the aquifer is feasible.

Q13. Many new MCLs will be promulgated or existing ones revised in upcoming years. Will new or revised MCLs, when promulgated, need to be incorporated into the remedy, possibly altering it? Should a proposed $M C L$ be used as the remediation goal in the ROD?

A. UnderEPA policy, if anew ARAR is promulgated after the RQD is signed the remedy should be examined in light of the new requirement to ensure that the remedy is still protective. If the remedy is still protective, it would not have to be modified, even though it does not meet the new requirement.

Since MCLs often are a key component in defining protective remediation levels, new or revised MCLs may reveal that the remedy chosen is not protective. In such cases, the remedy would have to be modified accordingly. This could occur at ariy time after the ROD is signed - during remedial design, remedial action, or at the five-year review.

However, a new MCL will not always mean the remedy must be changed. If the existing remedy is still within the risk range even considering the new MCL, the remedy would not have to be modified because the remedy is still protective. For example, if the new MCL represents a risk of $10^{-6}$, while the selected remediation level results in a $10^{-5}$ risk, the remedy is still protective.

At some sites, however, a new MCL will require significant changes to the remedy, changes that can be very costly after implementation of the remedy has begun. Therefore, if a proposed MCL is available before the ROD is signed, the preferred remedy should be evaluated to determine how the $\mathrm{MCL}$, if promulgated as proposed. would affect the remedy. Will the preferred remedy achieve the proposed MCL? Could the remedy achieve the proposed MCL with minor design modifications? Would the proposed MCL require significant changes, such as requiring remediation in ground water that is currently deemed fully protective because it meets all MCLs?

As a general rule, the proposed MCL should be used as a $I B C$ to establish the remediation level in the $R O D$ when the proposed MCL is more stringent than the existing one or regulates a new chemical (unless the MCL is controversial and therefore likely to change). This reflects the importance of MCLs in Superfund's determination of protectiveness and as a cleanup standard for the conmunity. It also minimizes the need for later changes to the remedy when changes may be more difficult and costly to make.

Q14. If there are MCLs for some, but not all, of the significant contaminants at a site, should the 10-6point of departure be used for all the contaminants, or should the MCLs be used where available and the remediation levels for the other contaminants adjusted accordingly?

A. Generally the MCLs should be used to set the remediation levels when available, provided the MCLs cumulatively are within the risk range. The levels for other chemicals should be set to ensure that they do not significantly increase the total risk associated with the chemicals with MCLs and that the cumulative risk from all chemicals is within the risk range. The $10^{-6}$ point of departure is used when there are no MCLs or, when risks are summed, when the MCLs for the chemicals in the medium are not sufficiently protective under the circumstances.

For example, if the risk from chemicals with MCLs totals $1 \times 10^{-5}$, the remediation levels for the other chemicals should generally be set so that the total cumulative risk does not exceed that risk level. Final levels for the chemicals without MCLs may also be driven by the treatment necessary to attain the MCLs.

For some mixtures of chemicals, it may be necessary or more technically practicable to adjust the remediation levels even of those chemicals with MCLs to more stringent levels. Even in such cases, the final remediation levels cannot exceed the respective MCLs, since the MCLs are ARARs, and the total risk of all contaminants should be within the risk range to ensure the remedy is protective. 


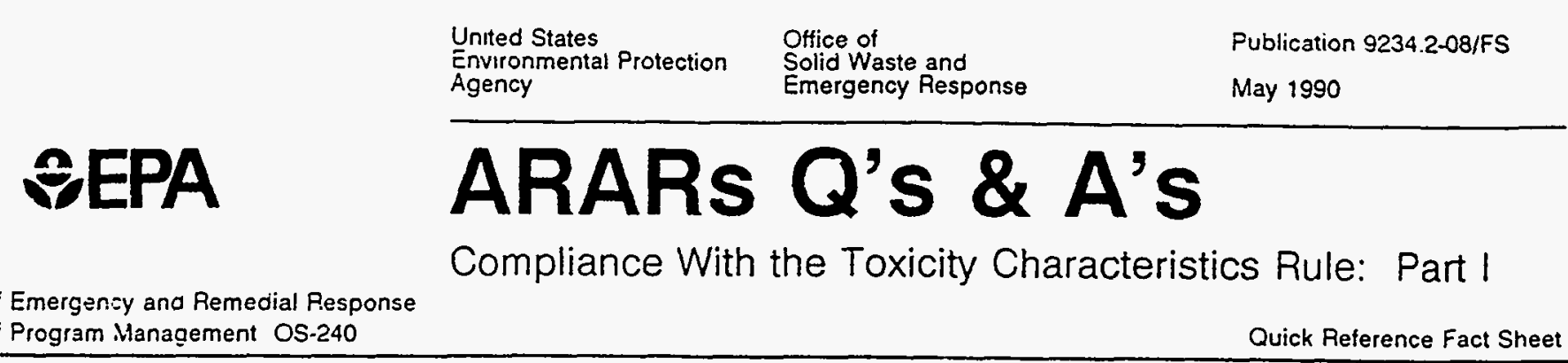

Section 121(d) of CERCLA, as amended by the 1986 Superfund Amendments and Reauthorization Act (SARA), requires that on-site remedial actions must at least attain (or justify a waiver of) Federal and more stringent State applicable and relevant and appropriate requirements (ARARs) upon completion of the remedial action. The 1990 National Contingency Plan (NCP) requires compliance with ARARs during remedial actions as well as at completion, and compels attainment of ARARs during removal actions, whenever practicable. See NCP, 55 FR 8666, 8843 (March 8, 1990) (to be codified at 40 CFR section 300.415(i)(1990)), and 55 FR 8666, 8852 (March 8, 1990) (to be codified at 40 CFR section $300.435(\mathrm{~b})(2)(1990))$.

To implement the ARARs provision, EPA has developed guidance, CERCLA Compliance With Other Laws Manual: Parts I and II (Publications 9234.1-01 and 9234.1-02), and has provided training to Regions and States on the identification of and compliance with ARARs. This "ARARs Q's and A's" is part of a series that provide guidance on a number of questions that arose in developing $A R A R$ policies, in ARAR training sessions, and in identifying and complying with ARARs at specific sites. This particular Q's and A's Fact Sheet addresses compliance with the recently promulgated Toxicity Characteristics Rule (55 FR 11798 (March 29, 1990)).

Q1. How are wastes characterized as hazardous under RCRA?

A RCRA Subtitle $C$ requirements are applicable to CERCLA response actions if the waste is a RCRA hazardous waste, and either the waste was initially treated, stored, or disposed of after the effective date of the particular RCRA requirement, or the activity at the CERCLA site constitutes treatment, storage, or disposal, as defined by RCRA. RCRA uses the following two procedures to define wastes as hazardous: (1) the listing procedure, which involves identifying specific industrial or process wastes that pose hazards to human health and the environment; and (2) the hazardous characteristics procedure, which involves identifying properties or "characteristics" that, if exhibited by any waste, indicate a potential hazard if the waste is not properly controlled. See 40 CFR section 261.3(a)(2). The new Toxicity Characteristics (TC) rule concerns one of four characteristics that indicate a potential hazard (the others are ignitability, reactivity, and corrosivity). A waste is a TC waste if any of the chemicals listed in Highlights 1 or 2 are found in the leachate at concentrations equal to or greater than their regulatory leveis.

\section{Hightight 1: NEW CHEMICALS REGULATED UNDER THE TC RULE AND THEIR LEACHATE REGULATORY LEVELS}

Benzene

Carbon tetrachloride

Chlordane

Chlorabenzene

Chloroform

m-Cresof

o-Cresol

p-Cresol

1,4-Dichlombenzente

1,2-Dichtoroethane

1,1-Dichloroethylene

2,4-Dinitrotoluene

Heptachlor (and its hydroxide)

Hexachlor-1,3-butadiene

Hexachloroberzene

Hexachtoroethane

Methyl etinyl ketone

Nürobenzene.

Pentachlorophenol

Pyridine

Tetrachlorocthyiene

Trichloroetbylene

2,4,5-Tricklorophenol

2,4,6-Trichlorophenol

Vinyl chloride

\begin{tabular}{|c|c|}
\hline 0.50 & $\mathrm{mg} /$ \\
\hline 0.50 & mgl \\
\hline 0.03 & mg \\
\hline 100.0 & \\
\hline 6.0 & \\
\hline 200.0 & \\
\hline 200.0 & \\
\hline 200.0 & \\
\hline 7.5 & \\
\hline 0.50 & \\
\hline $0.70^{\circ}$ & \\
\hline 0.13 & \\
\hline 0.008 & \\
\hline 0.5 & \\
\hline 0.13 & \\
\hline 3.0 & \\
\hline 200.0 & \\
\hline 2.0 & \\
\hline 100.0 & \\
\hline 5.0 & \\
\hline 0.7 & \\
\hline 0.5 & \\
\hline 400.0 & \\
\hline 2.0 & \\
\hline 0.20 & \\
\hline
\end{tabular}

- interim regulatory level 
Q2. What are the major provisions of the new TC rule?

A. The final TC rule adds 25 organic chemicals to the list of waste constituents which, if present in waste at or above the regulatory levels set in the rule (see Ilighlight 1), make the waste a hazardous waste. These 25 chemicals have been added to the 8 metals and 6 pesticides on the existing list of TC waste constituents (see Ilighlight 2 ). The TC rule also announced that 13 additional chemicals may be added to the TC list after EPA establishes their regulatory levels. Finally, the new TC rule replaces the Extraction Procedures (EP) with another test for determining toxicity (for both the new and existing chemicals regulated for the characteristic of toxicity). The new test is called the Toxicity Characteristics Leaching Procedure (TCLP). The impetus behind the development of the TCLP was the need to identify those wastes that are likely to leach hazardous concentrations of organic compounds.

Note: To determine compliance with RCRA land disposal regulations, the EP is still available for wastes that are not considered wastewater (i.e., for soils and sludges that contain more than $1 \%$ total suspended solids) and that contain either any amount of lead, or arsenic when it is the primary hazardous constituent (i.e., the highest constituent concentration) in the waste (see section $3(\mathrm{e})(8)$ of the final RCRA Third Third Rule, unpublished at the time of this printing).

\section{Highlight 2: CHEMICALS ALREADY REGULATED FOR TOXICITY CHARACTERISTICS AND THEIR LEACHATE REGULATORY LEVELS}

$\begin{array}{lr}\text { Arsenic } & 5.0 \mathrm{mg} / \\ \text { Barium } & 100.0 \mathrm{mg} / \\ \text { Cadmium } & 1.0 \mathrm{mg} / \\ \text { Chromium } & 5.0 \mathrm{mg} / \\ \text { Endrin } & 0.02 \mathrm{mg} / 1 \\ \text { Lead } & 5.0 \mathrm{mg} / 1 \\ \text { Lindane } & 0.4 \mathrm{mg} / 1 \\ \text { Mercury } & 0.2 \mathrm{mg} / \\ \text { Methoxychlor } & 10.0 \mathrm{mg} / 1 \\ \text { Selenium } & 1.0 \mathrm{mg} / 1 \\ \text { Silver } & 5.0 \mathrm{mg} / \\ \text { Toxaphene } & 0.5 \mathrm{mg} / 1 \\ \text { 2,4-Dichloro- } & \\ \text { phenoxycetic acid } & 10.0 \mathrm{mg} / 1 \\ \text { 2,4,5-Trichloropheno- } & \\ \text { xypropionic acid } & 1.0 \mathrm{mg} / 1\end{array}$

Q3. How does the new TC rule affect the regulatory levels of the potential TC wastes already regulated?

A. The regulatory levels of the eight metals and six pesticides remain the same (see Highlight 2 for their levels). These constituents must now be tested usin. the TCLP to determine whether they exceed their regulatory levels. It is important to note that the EP and the TCLP may produce different results; wastes not hazardous under the EP may be hazardous under the TCLP.

Q4. How does the TCLP differ in approach from the EP in identifying the toxicity characteristic?

A. The primary differences between the TCLP and the EP are: (1) the TCLP uses two leaching media where the medium is determined by the $\mathrm{pH}$ of the waste (there is no continual $\mathrm{pH}$ adjustment); (2) the TCLP requires the waste to be ground or milled (there is no structural integrity procedure); (3) the TCLP requires a shorter extraction time (18 hours for the TCLP versus 24 hours for the EP); and (4) the TCLP is easier to run and the test results are more easily reproduced.

Q5. What is the current status of the TC rule as a potential ARAR for the Superfund program?

A. The TC rule was promulgated on March 29,1990 . I became a potential ARAR for all decision document: (i.e., RODs and action memoranda) signed after that date. For actions carried out during the interim period prior to the effective date (i.e., September 25 , 1990), the TC rule would not be applicable, but may be relevant and appropriate.

Q6. How will the TC rule affect Superfund Records of Decision (RODs) that have already been signed?

A. The NCP states that ARARs "freeze" at the time of ROD signature. See 55 FR 8666, 8757, March 8, 1990, (to be codified at 40 CFR 300.430 (f)(1)(ii)(B)). TC requirements were promulgated on March 29, 1990 , and thus would not be ARARs for RODs signed before that date. For such RODs, the TC requirements are newly promulgated requirements, and thus should be attained only when EPA. determines that these requirements are ARARs, and that they must be met for the remedy to be protective. Newly promulgated or modified requirements like the TC rule will be considered during the 5-year review of the remedy, or sooner, if appropriate, to determine whether the remedy is still protective. Regions should review pre-TC ru' RODs to ensure that any on-site disposition $o_{1}$ wastes still meets the standard of protectiveness. (This issue will be discussed further in the 
forthcoming TC implementation Fact Sheet.) If EPA determines during the remedy review that the TC requirements must be attained, a ROD amendment or Explanation of Significant Differences (ESD) should be issued. See 55 FR 8666, 8757 (March 8, 1990) (to be codified at 40 CFR $300.430(\mathrm{f})(1)(\mathrm{ii})(\mathrm{B}))$.

Q7. What are some potential overall effects of the TC rule on the Superfund program?

A. Wastes containing any of the newly-regulated chemical constituents in the TC rule may be subject to RCRA regulations based on the toxicity characteristic, regardless of the source of a particular waste or whether the waste is a RCRA listed waste. In addition, because the TC rule expands the list of potential TC wastes that need to be evaluated for the characteristic of toxicity, the amount of wastes considered to be RCRA hazardous wastes at a
CERCLA site will potentially expand. Once a waste is considered to be a RCRA hazardous waste, other RCRA requirements may be applicable or relevant and appropriate, such as closure, minimum technology disposal restrictions, and the land disposal restrictions. In addition, remedial alternatives involving off-site shipment of TC wastes must involve Subtitle C facilities, rather than Subtitle D facilities.

NOTICE: The policies set out in this fact sheet are intended solely as guidance. They are not intended, nor can they be relied upon, to create any rights enforceable by any party in litigation with the United States. EPA officials may decide to follow the guidance provided in this fact sheet, or to act at variance with the guidance, based on an analysis of specific site circumstances. The Agency also reserves the right to change this guidance at any time without public notice.

In the near future, OERR will issue another Fact Sheet that discusses technical issues that may arise during the implementation of the TC rule at Superfund sites. The TC implementation Fact Sheet will be Part II to this ARARs Q's \& A's Fact Sheet on the TC rule. 